\title{
CARACTERIZAÇÃO GENÉTICA E CITOLÓGICA DA RECOMBINAÇÃO SOMÁTICA \\ EM Trichoderma pseudokoningii
}

\author{
FERNANDO GOMES BARCELLOS
}

\author{
Tese apresentada à Escola Superior de \\ Agricultura "Luiz de Queiroz", Universidade \\ de São Paulo, para a obtenção do título \\ de Doutor em Agronomia, Área de concentração: \\ Genética e Melhoramento de Plantas.
}

\section{PIRACICABA}

Estado de São Paulo - Brasil

Julho -2002 


\section{CARACTERIZAÇÃO GENÉTICA E CITOLÓGICA DA RECOMBINAÇÃO SOMÁTICA EM Trichoderma pseudokoningii}

\section{FERNANDO GOMES BARCELLOS}

Biólogo

Orientadora: Profa. Dra. ALINE APARECIDA PIZZIRANI-KLEINER

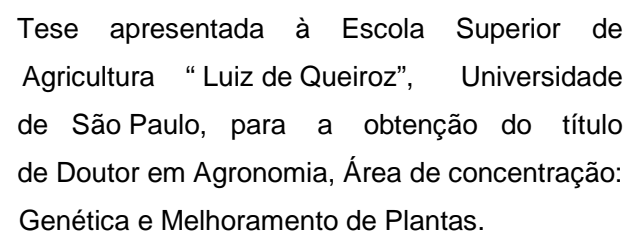

\section{PIRACICABA}

Estado de São Paulo - Brasil

$$
\text { Julho }-2002
$$




\section{Dados I nternacionais de Catalogação na Publicação (CIP) DI VISÃO DE BI BLIOTECA E DOCUMENTAÇÃO - ESALQ/ USP}

Barcellos, Fernando Gomes

Caracterização genética e citológica da recombinação somática em Trichoderma pseudokoningii / Fernando Gomes Barcellos. - - Piracicaba, 2002.

92 p. : il.

Tese (doutorado) - Escola Superior de Agricultura Luiz de Queiroz, 2002.

Bibliografia.

1. Ciclo parassexual 2. Fungo celulolítico 3. Genética microbiana 4. Recombinação mitótica 5. Trichoderma I. Título

CDD 589.2

"Permitida a cópia total ou parcial deste documento, desde que citada a fonte - $\mathrm{O}$ autor" 
A Deus que sempre me conduziu e me capacitou,

À minha mãe Doronice

Ao meu pai Sebastião

Aos meus irmãos Adriana, Márcia e Samuel

Aos meus sobrinhos Talyta e Henrique

À minha avó Odete e ao meu avô Francisco

Aos meus cunhados Günter e Wilson

Dedico 


\section{AGRADECIMENTOS}

- À Profa. Dra. Aline Aparecida Pizzirani-Kleiner pela valiosa orientação, constante apoio e amizade;

- À Profa. Dra. Maria Helena Pelegrinelli Fungaro pela amizade e incentivo;

- Ao Prof. Dr. João Lúcio de Azevedo pela amizade, incentivo e sugestões;

- À Margarete Nadaline pela amizade, colaborações e incentivos;

- À Mayra, Ágata, Taís, Adalgisa e Luciana pela nossa amizade e companheirismo, por todos os momentos alegres e também pelos momentos de lutas e dificuldades que juntos compartilhamos, pelas palavras de apoio e incentivo;

- Ao Wellington L. Araújo pelo constante apoio, ajuda, sugestões, amizade e companheirismo;

- Ao André S. Lima, Paulo Lacava, Ricardo Yara (Pipa) e Walter Maccheroni pela amizade e companheirismo;

- Aos amigos do laboratório: Júlia, Joelma, Beatriz, Cláudia, Estela Durán, Jucymeire, Rosemeire Bueno, Priscila, Carolina, Rudi Emerson, Rodrigo, Fernando, Sérgio e Marcelo; 
- Ao amigo e técnico do laboratório: José Antônio da Silva (Zezo).

- Ao CNPq pela apoio financeiro;

- Aos Professores e colegas do Programa de Genética e Melhoramento de Plantas;

- À secretária da pós-graduação Léia e demais funcionários do Departamento de Genética. 


\section{SUMÁRIO}

Página

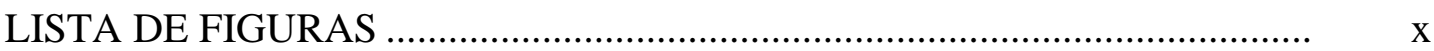

LISTA DE QUADROS........................................................................

LISTA DE TABELAS …................................................................... xiii

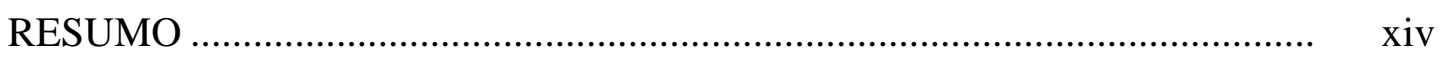

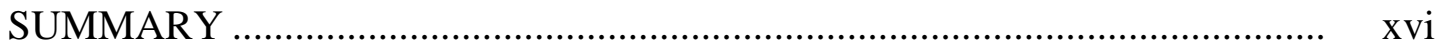

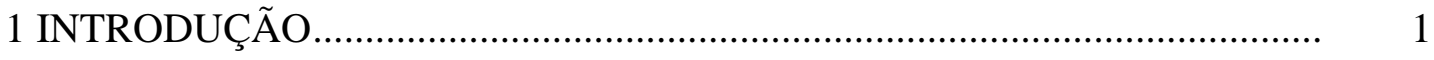

2 REVISÃO DA LITERATURA .......................................................... 3

$2.1 \mathrm{O}$ gênero Trichoderma: características biológicas e importância .................. 3

2.2 Processos parassexuais de recombinação em fungos ................................... 6

2.2.1 Variações nos processos parassexuais de recombinação............................. 8

2.2.2 Anastomose de hifas: incompatibilidade vegetativa e observações

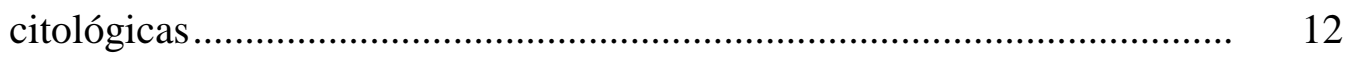

2.2.3 Estudos da recombinação somática ou vegetativa no gênero

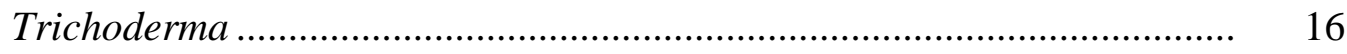

3 MATERIAL E MÉTODOS ................................................................... 23

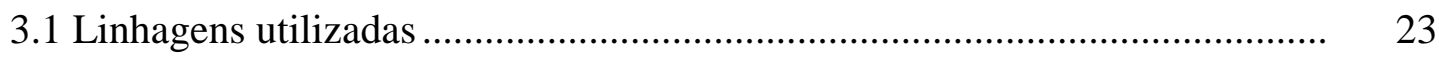

3.1.1 Trichoderma pseudokoningii............................................................. 23

3.1.2 Linhagens de Trichoderma pseudokoningii ............................................ 23

3.2 Meios de cultura e soluções..................................................................... 24

3.2.1 Meio Mínimo - MM ............................................................................. 24

3.2.2 Meio Completo - MC …...................................................................... 24

3.2.3 Meios mínimo e completo líquido....................................................... 24

3.2.4 Meio mínimo mais 4\% de meio completo - $(\mathrm{MM}+4 \% \mathrm{MC})$................... 25 
Página

3.2.5 Solução de vitaminas adicionada ao MC................................................ 25

3.2.6 Suplementos adicionados ao meio mínimo ............................................ 25

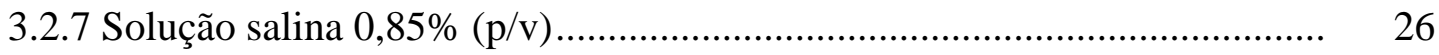

3.2.8 Solução de tween 80 0,1\% (v/v)......................................................... 26

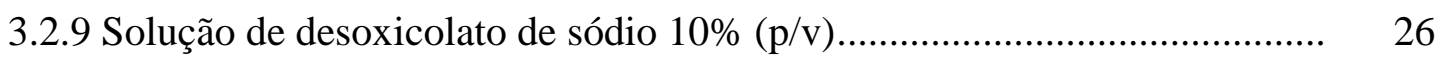

3.2.10 Solução de albumina 5\% (v/v) ........................................................... 26

3.2.11 Solução de Giemsa ........................................................................... 27

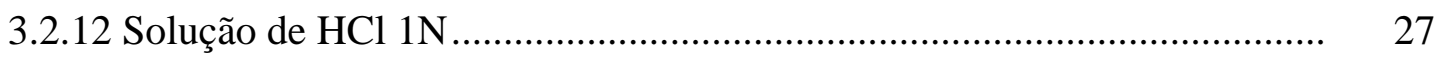

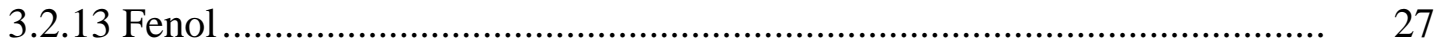

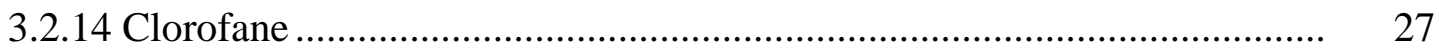

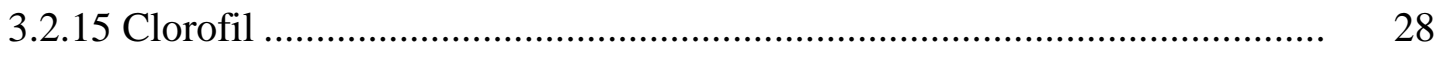

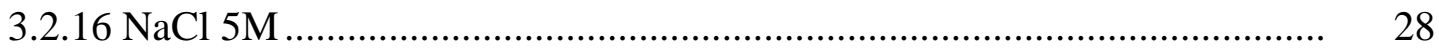

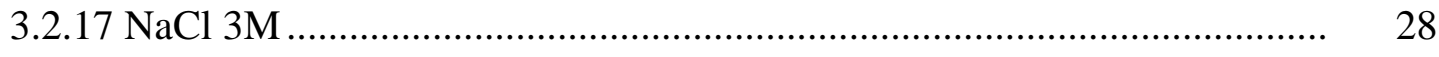

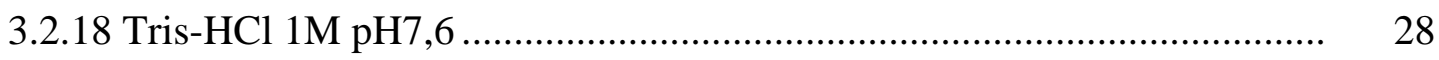

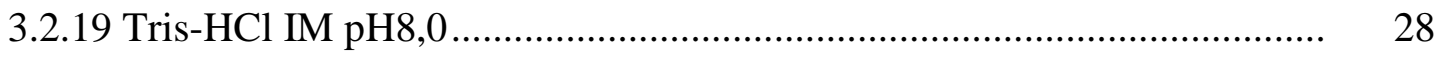

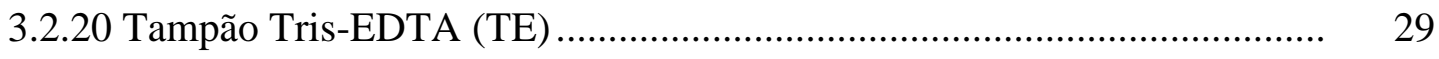

3.2.21 Tampão de extração de DNA ................................................................. 29

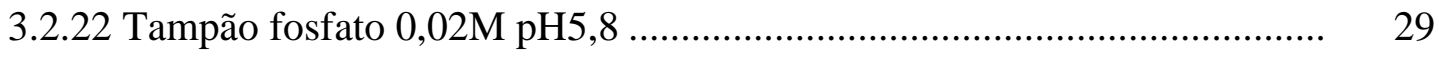

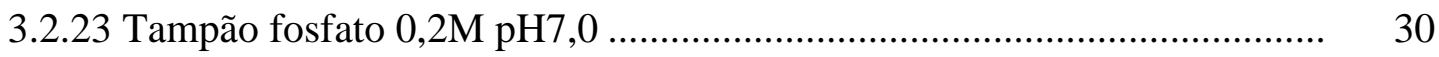

3.2.24 Solução de $\mathrm{KCl} 0,6 \mathrm{M}$ pH 5,8 ........................................................... 30

3.2.25 Ácido Etilendinitrilotetracético sal dissódico (EDTA) 0,5M pH8,0 ........ 31

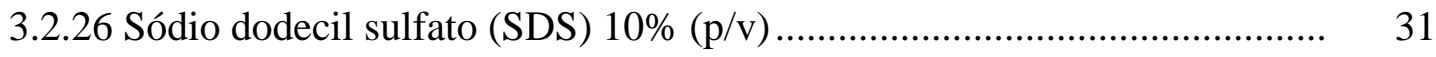

3.2.27 Solução de NDS ................................................................................ 31

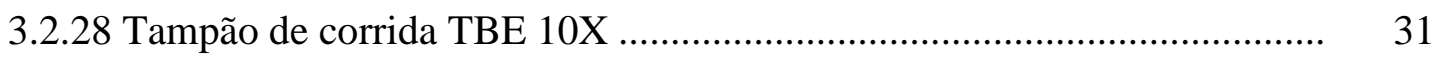

3.2.29 Tampão de McIlvaine's pH5,8 .............................................................. 32

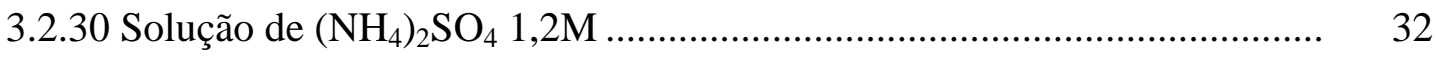

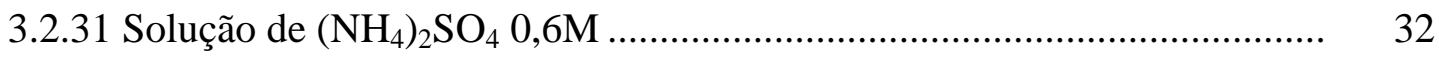

3.2.32 Gel de agarose para confecção dos "plugs"............................................. 32

3.2.33 Gel de agarose para eletroforese em campo pulsado.............................. 33 
Página

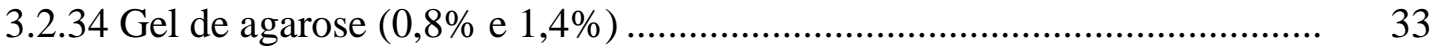

3.2.35 Solução de brometo de etídio .............................................................. 33

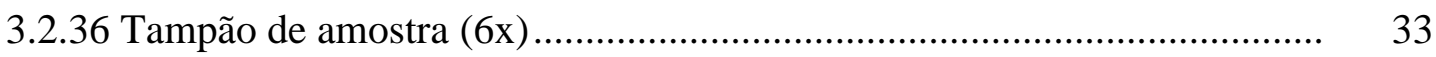

3.3 Esterilização e incubação ...................................................................... 34

3.4 Coloração de núcleos pelo método $\mathrm{HCl}$-Giemsa............................................ 34

3.5 Análise genética.............................................................................. 35

3.5.1 Obtenção de heterocários .................................................................. 35

3.5.2 Isolamento das colônias prototróficas e outros recombinantes .................. 35

3.5.3 Análise dos recombinantes ................................................................ 35

3.6 Obtenção de protoplastos ..................................................................... 36

3.7 Preparação dos "plugs"para eletroforese em campo pulsado ........................ 36

3.8 Separação de cromossomos de T. pseudokoningii por eletroforese em campo pulsado - PFGE................................................................................ 37

3.9 Extração de DNA de fungos filamentosos .................................................. 38

3.10 Amplificação de DNA por RAPD ....................................................... 38

3.11 Reamplificação de bandas isoladas dos géis de RAPD ............................. 39

3.12 Sequiênciamento das bandas de RAPD reamplificadas ............................. 39

4 RESULTADOS E DISCUSSÃO _............................................................ 41

4.1 Seleção das linhagens para a realização dos cruzamentos ........................... 41

4.2 Cruzamentos por anastomose de hifas ................................................. 44

4.3 Análise dos recombinantes por RAPD ................................................... $\quad 56$

4.4 Reamplificação de bandas isoladas de RAPD ............................................. 63

4.5 Separação dos cromossomos por eletroforese em campo pulsado (PFGE) ... 67

4.6 Estudos Citológicos ................................................................................ 70

4.6.1 Número de núcleos nos conídios das linhagens parentais e recombinantes e estudos da conidiogênese............................................................... 70

4.6.2 Estudos das anastomoses de hifas e do comportamento nuclear durante os processos de formação do heterocário................................................. 74 
Página

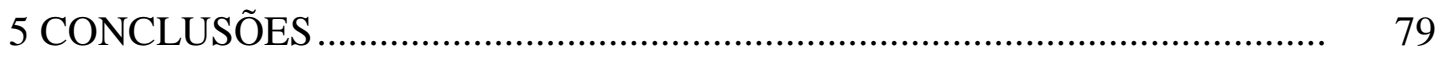

REFERÊNCIAS BIBLIOGRÁFICAS .................................................... 81 


\section{LISTA DE FIGURAS}

Página

1 Perfil de bandas de RAPD das linhagens de T. pseudokoningii...................... 42

2 Linhagens selecionadas para a realização dos cruzamentos com base no perfil de bandas RAPD, marcadores de auxotrofia e coloração dos

conídios

3 Contraste no perfil de bandas RAPD entre as linhagens 9 e 12 utilizadas nos cruzamentos.

4 Etapas do processo de obtenção e análise das colônias recombinantes

5 Proporção de fenótipos parentais das colônias isoladas a partir do heterocário

6 Colônias recombinantes crescidas em meio completo (MC)

7 Aspecto de crescimento das colônias em meio completo (MC) sem a suplementação do inositol

8 RAPD de 49 recombinantes e dos parentais 9L e 12L com o primer AX17..

9 RAPD de 47 recombinantes e das linhagens parentais 9L e 12L com o primer AX03.

10 RAPD de 48 recombinantes e das linhagens parentais 9L e 12L com o primer $\mathrm{X} 17$

11 RAPD de 50 recombinantes e das linhagens parentais 9L e 12L com o primer $\mathrm{P} 19$

12 Reamplificação de bandas de DNA (setas) isoladas dos géis de agarose das amplificações de RAPD 
Página

13 Construção de um par de primers com base na seqüência de nucleotídeos de uma banda (seqüência) amplificada por RAPD com o primer A7 e a utilização destes em reações de PCR ............................................................. 66

14 Separação dos cromossomos por eletroforese em campo pulsado das linhagens parentais 9L e 12L e de cinco recombinantes ............................... 68

15 Coloração de núcleo dos conídios ............................................................... 71

16 Estudo da distribuição nuclear durante o processo de conidiogênese............. 73

17 Observações citológicas da formação do heterocário, das anastomoses de hifas, e do comportamento nuclear durante os processos de formação do heterocário 


\section{LISTA DE QUADROS}

Página

1 Análise da estabilidade dos marcadores de auxotrofia das colônias

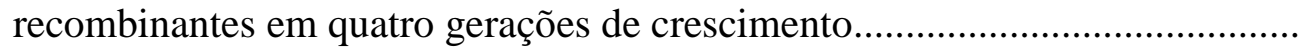

2 Representação esquemática das bandas cromossomais apresentadas na

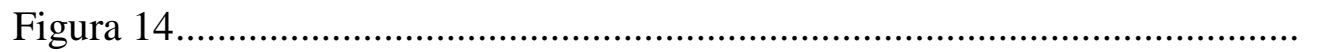




\section{LISTA DE TABELAS}

Página

1 Isolamento de colônias parentais e recombinantes a partir de suspensões de conídios obtidas dos heterocários de quatro cruzamentos entre as linhagens

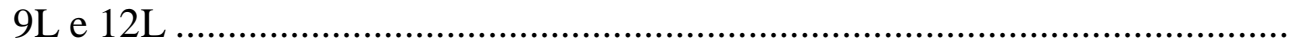

2 Proporção de fenótipos parentais (9L ou 12L) das colônias isoladas, em meio completo (MC), a partir de suspensões de conídios obtidas dos

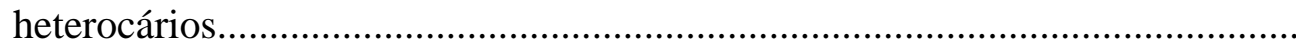

3 Crescimento diferenciado em meio seletivo entre as colônias parentais 9L e $12 \mathrm{~L}$ 


\title{
CARACTERIZAÇÃO GENÉTICA E CITOLÓGICA DA RECOMBINAÇÃO SOMÁTICA EM Trichoderma pseudokoningii
}

\author{
Autor: FERNANDO GOMES BARCELLOS \\ Orientadora: Profa. Dra. ALINE APARECIDA PIZZIRANI-KLEINER
}

\section{RESUMO}

Com o objetivo de se caracterizar o processo de recombinação somática em Trichoderma pseudokoningii foram feitos cruzamentos via anastomose de hifas entre duas linhagens contrastantes para quatro marcadores de auxotrofia, coloração dos conídios e marcadores de RAPD. Foram feitos quatro cruzamentos, sendo analisados um total de 1052 colônias obtidas a partir de suspensões de conídios provenientes das colônias heterocarióticas. Sessenta e oito colônias recombinantes foram analisadas quanto às marcas de auxotrofia em quatro gerações de crescimento, sendo observado que 58 mantiveram o fenótipo recombinante, enquanto que as colônias restantes reverteram para um dos parentais. A maioria das colônias recombinantes se mostrou instável. Entretanto, após 4 gerações de crescimento estas colônias se tornaram estáveis para as marcas de auxotrofia avaliadas. As colônias recombinantes instáveis apresentaram bordas de crescimento irregular, esporulação esparsa e a freqüente formação de setores. Estas colônias recombinantes foram analisadas quanto aos marcadores RAPD, tendo mostrado grande similaridade, em relação ao perfil de bandas apresentado, com a maioria dos primers analisados. Somente com um primer foi possível visualizar a presença de uma banda polimórfica entre os recombinantes e a presença de bandas nos parentais não existentes em alguns recombinantes. Cinco colônias recombinantes foram 
analisadas quanto ao perfil de bandas cromossomais (PFGE), tendo sido observado que 2 colônias apresentaram padrões cromossomais igual a um dos parentais e 3 colônias apresentaram padrões recombinantes. Nos estudos citológicos verificou-se a formação de conídios uninucleados na conidiogênese, e a presença de conídios verdes maduros multinucleados, devido a prováveis divisões nucleares durante o processo de maturação dos conídios. Observou-se durante a formação dos heterocários a ocorrência de anastomoses e a passagem de núcleos, tendo sido observado a presença de núcleos com várias conformações, sugerindo um movimento ativo dos mesmos. Os resultados acima sugerem a ocorrência de mecanismos de recombinação no heterocário (recombinação somática), diferentes daqueles descritos para o ciclo parassexual ou parameiose, sendo proposto a ocorrência da degradação, no heterocário, dos núcleos de um dos parentais envolvidos nos cruzamentos (parental não prevalente) e a incorporação de segmentos destes em núcleos íntegros do parental prevalente. Se estes eventos realmente estiverem ocorrendo, sugere-se que estes sejam devido a possíveis reações limitadas de incompatibilidade vegetativa, ocasionando processos de lise e morte celular em algumas regiões do micélio heterocariótico. 


\title{
GENETIC AND CYTOLOGICAL CHARACTERIZATION OF THE SOMATIC RECOMBINATION IN
}

\section{Trichoderma pseudokoningii}

\author{
Author: FERNANDO GOMES BARCELLOS \\ Adviser: Profa. Dra. ALINE APARECIDA PIZZIRANI-KLEINER
}

\section{SUMMARY}

To understand the somatic recombination process in Trichoderma pseudokoningii, auxotrophic complementary mutant strains were used to produce 4 heterokaryons. These strains were contrasting for four auxotrophic markers, conidia colors and for some RAPD markers. It was analyzed a total of 1052 colonies obtained from conidial suspensions of the heterokaryotic colonies. Stability of auxotrophic markers was evaluated in 68 recombinant colonies after four growing generations. In this analysis, 58 colonies kept the recombinant phenotype, while 10 reverted to one parental strain. Most of the recombinant colonies were initially unstable, but after at least 4 growing generations these recombinants became stable for auxotrophic markers. The unstable recombinant colonies showed irregular growing borders, sparse sporulation and frequent sector formation. The recombinant colonies were analyzed by RAPD technique. These colonies showed high similarity for the most of used primers. However, one primer showed a polymorphic band and some recombinants missing bands observed in parental strains. Chromosomal band profile of 5 recombinants and two parental strains were analyzed by Pulsed Field Gel Electrophoresis technique (PFGE). Two recombinants showed parental profiles and 3 showed recombinant profiles, respectively. In cytological studies of the conidiogenesis was observed the 
formation of only uninucleated conidia. However, presence of multinucleated mature green conidia was evident, probably due to nuclear divisions in course of maturing process of the conidia. During the process of heterokaryotic mycelium formation was possible to observe the occurrence of anastomosis that showed nuclear transfer. The presence of nuclei in several conformations was observed at the different regions of the heterokaryon, suggesting an active movement. The results presented in this study suggest the occurrence of recombination mechanisms in the heterokayon (somatic recombination), different from those described in classic parasexual cycle or parameiosis. Thus, it was proposed that may occur during this recombinant process the degradation of nuclei from one parental (non-prevalent parental) in the heterokaryon, and that the resulting chromosomal fragments may be incorporated into whole nuclei of the another parental (prevalent parental). If this natural transformation is occurring during this recombination process could be suggested that this event is due to a limited incompatible vegetative reactions, generating cellular lyses and death in some regions of the heterokaryotic mycelium. 


\section{INTRODUÇÃ̃o}

O gênero Trichoderma é constituído por um complexo grupo de espécies, denominado de agregado de espécies relacionadas, comumente encontradas no ambiente, especialmente nos solos. Espécies deste gênero têm sido utilizadas na produção de enzimas celulolíticas e hemicelulolíticas, no controle biológico de fitopatógenos principalmente da raiz de muitas plantas cultivadas, na biodegradação de compostos clorofenólicos e na biorremediação do solo (Esposito \& Silva, 1998).

Devido a importância das espécies deste gênero nas diversas áreas de aplicação, se faz necessário a obtenção de linhagens superiores apresentando características desejáveis para a utilização a nível comercial e industrial. A maioria das espécies utilizadas atualmente foram isoladas diretamente do ambiente, sendo algumas submetidas a processos de mutação-seleção (Esposito \& Silva,1998; Samuels, 1996). Faz-se necessária portanto a utilização de processos de recombinação para unir características desejáveis e otimizar o aproveitamento do potencial genético das diferentes linhagens isoladas de Trichoderma.

No gênero Trichoderma a fase sexuada de reprodução não foi descrita. Entretanto sabe-se que a fase perfeita deste fungo é relacionada ao ascomiceto Hypocrea, pois muitas espécies desse gênero, incluindo Trichoderma pseudokoningii, foram isoladas a partir de ascósporos de Hypocrea (Samuels, 1996).

No entanto foi descrito em várias espécies do gênero, a obtenção de recombinantes via processos de recombinação somática, por anastomose de hifas ou fusão de protoplastos. Na maioria destes processos foram identificadas características 
comuns como, obtenção de recombinantes de crescimento lento em meio seletivo e instáveis com a formação de setores, recombinantes com a maioria dos marcadores genéticos em estudo de somente um dos parentais (Stasz \& Harman, 1990).

Assim o presente trabalho se propôs a estudar o processo de obtenção de recombinantes (recombinação somática) na espécie T. pseudokoningii para uma melhor aplicação de métodos de cruzamentos entre linhagens em programas de melhoramento da espécie. Para isto objetivou-se:

- A formação de heterocários por anastomose de hifas entre mutantes auxotróficos apresentando marcadores complementares e a seleção de recombinantes, estimativa das freqüências de ocorrência e a caracterização dos mesmos;

- A análise citológica dos heterocários, quanto às anastomoses de hifas e distribuição dos núcleos na formação dos conídios nas linhagens parentais, no heterocário e nos recombinantes além da caracterização do número de núcleos nos conídios maduros;

- A análise via marcadores RAPD dos parentais e recombinantes;

- A separação dos cromossomos por eletroforese em campo pulsado das linhagens parentais e de alguns recombinantes, para a verificação de possíveis alterações nos perfis de bandas cromossomais entre as referidas linhagens. 


\section{REVISÃO DA LITERATURA}

\subsection{O gênero Trichoderma: características biológicas e importância}

As espécies do gênero Trichoderma são comuns no meio ambiente, especialmente nos solos (Samuels, 1996). Elas têm sido utilizadas na produção de muitas exoenzimas em escala industrial como por exemplo, as enzimas celulolíticas, além de serem amplamente utilizadas no controle biológico de doenças de plantas. Algumas espécies têm sido estudadas e utilizadas em processos de biodegradação de compostos clorofenólicos e na biorremediação do solo (Esposito \& Silva, 1998). O conhecimento do que constitui uma espécie do gênero a nível morfológico ainda não está definido, nem mesmo as inter-relações entre as espécies do gênero (Samuels, 1996). Também, pouco se conhece sobre a biologia de muitas das espécies, como o ciclo de vida e modos de reprodução e recombinação. Devido ao fato de que, no gênero Trichoderma, as características morfológicas que definem uma espécie serem muito variáveis, tem sido utilizado pelos taxonomistas o termo de agregado de espécies (Samuels, 1996), sendo definidos como grupos de espécies morfologicamente muito semelhantes. Foram propostos inicialmente por Rifai (1969) nove agregados de espécies, os quais foram elevados ao nível de seção por Bisset (1984; 1991 a, b e c). Devido ao isolamento de espécies de Trichoderma a partir de ascósporos do gênero Hypocrea (pertencente aos ascomicetos), estes são atualmente classificados como formas anamórficas deste gênero e de gêneros relacionados (Samuels, 1996). As espécies do gênero são caracterizadas por apresentarem crescimento rápido, atingindo de dois a nove centímetros de diâmetro após quatro dias de crescimento em meio de cultura (Esposito \& Silva, 1998). As colônias podem se apresentar dispersas e flocosas ou compactadas 
em tufos. O tamanho e o formato dos conídios é muito variável e de limitado valor taxonômico. São observados nas espécies de Trichoderma a existência de clamidósporos, os quais são esporos assexuais originados pela modificação de segmentos da hifa, podendo ser intercalares ou terminais. Os conídios podem ser verdes, amarelos ou em tons verdes amarelados e ainda incolores. Não existe em Trichoderma conidióforos definidos (Samuels, 1996), sendo os conídios formados nas extremidades das fiálides em determinadas hifas diferenciadas. Os conídios tendem a se agregar em massas, sendo estes agregados constituídos de hifas contendo fiálides. Em algumas espécies do gênero existe uma dependência de luz para a esporulação (Gressel \& Hartmann, 1968).

A espécie T. pseudokoningii cresce rapidamente e suas colônias atingem de 8$9 \mathrm{~cm}$ de diâmetro após 4 dias de incubação ao redor de $28^{\circ} \mathrm{C}$ (Bisset, 1984). Apresenta micélio translúcido e esparso, com pouco crescimento aéreo, composto de hifas ramificadas, septadas, parede lisa e sem cor. Os conidióforos são em tufos, tornando-se pulverulentos na maturidade. Os primeiros conidióforos formam zonações, tornando-se indistintos posteriormente. Os conídios são produzidos isoladamente e sucessivamente, na extremidade de cada fiálide, apresentando-se subcilíndricos ou oblongos e algumas vezes elipsóides. Com relação à coloração, estes apresentam-se desde branco-esverdeado até verde (Rifai,1969). Foram observados conídios uninucleados (Furlaneto, 1989), e binucleados principalmente em colônias selecionadas a partir de heterocários (Furlaneto \& Pizzirani-Kleiner, 1992; Nadalini, 1997).

Esta espécie é capaz de degradar celulose. Nadalini et al., (1999) ao quantificarem a produção de celulases em linhagens mutantes, verificaram um aumento na produção em uma linhagem mutante em relação à forma selvagem original, demonstrando a utilidade do método de indução de mutação - seleção para a obtenção de linhagens hiperprodutoras.

O gênero Trichoderma está amplamente distribuído por todo o mundo e ocorre em quase todos os tipos de solos e ambientes naturais, especialmente naqueles contendo matérias orgânicas (Esposito \& Silva, 1998). Muitas espécies do gênero são também encontradas na rizosfera de muitas plantas. $O$ fato das espécies do gênero se 
desenvolverem em um amplo espectro de substratos e condições ambientais, torna este grupo de grande interesse biotecnológico (Esposito \& Silva, 1998).

As espécies do gênero Trichoderma produzem grandes quantidades de celulases e outras enzimas hidrolíticas (Kubicek, 1992) sendo Trichoderma reesei um conhecido produtor de múltiplas enzimas celulolíticas e hemicelulolíticas. Neste contexto, Margolles-Clark et al. (1997) estudaram o padrão de expressão de dez genes de hemicelulase de $T$. reesei em várias fontes de carbono. As espécies do gênero Trichoderma podem ser utilizadas na reciclagem de materiais celulósicos para a obtenção de resíduos úteis (Esposito \& Silva, 1998). As xilanases são produzidas em escala industrial, principalmente por espécies de Trichoderma e Aspergillus (Haltrich et al., 1996). As xilanases são utilizadas na indústria de alimentos, rações e de papel. Outras enzimas produzidas por espécies de Trichoderma são as quitinases, característica esta que pode estar relacionada à capacidade destas de atuar como micoparasitas, onde estas enzimas atuariam na digestão das paredes celulares fúngicas (Lorito et al., 1993).

As espécies de Trichoderma têm sido usadas em preparações comerciais para o controle biológico de fungos causadores de doenças em plantas, reduzindo a necessidade de utilização de poluentes químicos. O fungo Trichoderma harzianum é o agente ativo do composto comercial "Tricodex", o qual é utilizado contra o fungo causador do apodrecimento pós - colheita da maçã, e é utilizado em combinação com o fungo $T$. polysporum no composto denominado "Binab-T", o qual é utilizado no controle do apodrecimento da madeira (Ricard, 1981). Uma linhagem de $T$. harzianum ( $T$. harzianum AG2), obtida à partir de fusão de protoplastos, é utilizada no controle de um grande espectro de doenças de plantas transmitidas via solo (Harman, 1990). O composto "GlioGard" possui o fungo Trichoderma virens como seu agente ativo e é utilizado na prevenção do tombamento de plântulas causado por espécies de Pythium e Rhizoctonia (Lumsden \& Locke, 1989).

As espécies do gênero Trichoderma são reconhecidas como organismos controladores do solo em ambientes florestais, devido ao fato de estarem envolvidos em processos de decomposição, na reciclagem de nutrientes e na regulação da micobiota associada (Esposito \& Silva, 1998). Tem sido evidenciado a importância das espécies de 
Trichoderma na decomposição de compostos xenobióticos (Smith, 1995). T. harzianum e Trichoderma viride são capazes de degradar compostos organoclorados "in vitro". A persistência de contaminantes organoclorados nos solos pode ser influenciada pela presença de fungos que possam degradá-los como T. harzianum e T. viride (Smith, 1995). O fungo T. harzianum é capaz de degradar compostos clorofenólicos incluindo vários pesticidas como "Glifosato", "DDT", "Dieldrin", "Endosulfan", etc. (Katayama \& Matsumura, 1993). T. viride é capaz de degradar o inseticida "Photodieldrin" em compostos não tóxicos e solúveis em água (Tabet \& Lichtenstein, 1976).

O gênero Trichoderma apresenta um excelente potencial para a aplicação em várias áreas de interesse agrícola, ambiental e industrial. Portanto, um melhor conhecimento da taxonomia, da definição de espécie, assim como estudos do ciclo de vida, formas de reprodução e recombinação, estudos fisiológicos, bioquímicos entre outros, tornam-se necessários para um melhor aproveitamento do potencial destes fungos nas diversas áreas de interesse (Esposito \& Silva, 1998).

\subsection{Processos parassexuais de recombinação em fungos}

Pontecorvo et al. (1953) trabalhando com o fungo ascomiceto Aspergillus nidulans descreveram pela primeira vez a ocorrência da recombinação via ciclo parassexual (também denominado de recombinação mitótica ou recombinação somática). O termo parassexualidade foi, portanto inicialmente proposto por Pontecorvo (1956) para definir aqueles processos, diferentes dos processos sexuais de reprodução, os quais resultam na obtenção de recombinantes entre linhagens fúngicas. O ciclo parassexual como originalmente descrito consiste essencialmente das seguintes sequiências de eventos (Debets, 1998): (i) anastomose de hifas de homocários de diferentes genótipos resultando em um micélio heterocariótico; (ii) fusão de dois núcleos haplóides diferentes gerando um diplóide heterozigoto; (iii) recombinações mitóticas ("crossing-over" mitótico) ocasionais durante a multiplicação dos núcleos diplóides; e (iv) não-disjunções levando ocasionalmente, via sucessivos estados de aneuploidia, a um recombinante haplóide. Portanto, como na recombinação que ocorre na meiose, existem 
recombinações intracromossomais ("crossing-over") e intercromossomais (nãodisjuncionais), mas, diferindo da meiose, não existe coordenação precisa entre estes processos de fusão nuclear, recombinação e redução do número de cromossomos (Debets, 1998).

A recombinação via processos parassexuais tem sido demonstrada na maioria dos fungos pesquisados (Debets, 1998), estes incluem fungos de importância industrial, entomopatogênicos, fitopatogênicos, antagonistas de fitopatógenos, de interesse médico entre outros. Evidências para recombinação via processos parassexuais têm sido encontradas, portanto, em espécies das principais classes de fungos.

Existe ainda uma certa dúvida em relação à importância dos processos de recombinação parassexuais nas populações naturais de fungos (Debets, 1998). Uma evidência direta da ocorrência natural dos processos parassexuais é fornecida pelo isolamento de linhagens diplóides somáticas em várias espécies de fungos, entre estas incluem: Ustilago maydis, Verticillium dahliae, V. albo-atrum, Aspergillus niger e A. nidulans entre outras (Caten, 1981). Na natureza como no laboratório, espera-se que os diplóides somáticos sofram processos espontâneos de recombinação mitótica e haploidização, mas estes eventos são de difícil observação sob condições naturais (Caten, 1981). No entanto Zeigler et al. (1997) descreveram a existência de fluxo ou trocas de DNA via processos parassexuais em isolados selvagens de Magnaporthe grisea. Os resultados sugeriram a ocorrência de recombinação via processos parassexuais em populações naturais de $M$. grisea e que isto fornece um importante mecanismo para gerar variação genética e eliminar mutações deletérias acumuladas em linhagens clonais (Zeigler et al., 1997).

Os processos parassexuais de recombinação têm sido utilizados extensivamente em análises genéticas de fungos onde se detectou somente recombinação via ciclo parassexual e também naqueles cuja recombinação foi demonstrada tanto via ciclo parassexual como sexual (Debets, 1998). Estes dois tipos de recombinantes fornecem informações úteis sobre o grupo de ligação de marcadores (recombinantes intercromossomais resultantes da segregação cromossômica) ou a ordem dos genes nos grupos de ligação em relação ao centrômero (recombinantes obtidos a partir de 
"crossing-over" intracromossomal). Desta forma tem sido construído o mapa genético de vários fungos onde se observou somente a ocorrência de recombinantes via processos parassexuais, como os fungos Penicillium chrysogenum (Bueno-Gomes, 2000) Beauveria bassiana (Bello \& Paccola-Meirelles, 1998), T. pseudokoningii (Nadalini, 1997); A. niger (Debets et al., 1993); Metarhizium anisopliae (Bagagli et al., 1991) entre muitos outros.

\subsubsection{Variações nos processos parassexuais de recombinação}

Desde que foi identificado em A. nidulans, o ciclo parassexual como originalmente descrito tem sido demonstrado ocorrer em muitos Ascomicetos, Deuteromicetos e em heterocários de Basidiomicetos. No entanto, em um grande número de espécies de fungos os processos parassexuais de recombinação não parecem ocorrer conforme o ciclo parassexual padrão descrito, sendo que em algumas espécies as diferenças são tantas que sugere que outros mecanismos diferentes da parassexualidade podem estar envolvidos (Caten, 1981; Clutterbuck, 1996; Debets, 1998).

Os diferentes estágios dos processos parassexuais de recombinação podem variar consideravelmente entre as diferentes espécies estudadas. Em muitos casos algumas das etapas foram consideradas transientes por não terem sido detectadas, por exemplo, em Humicola sp. os diplóides aparecem diretamente em culturas mistas de mutantes auxotróficos crescidos em meio mínimo, sem a detecção da formação de um heterocário (Bertoldi \& Caten, 1975). Em outros fungos a fase diplóide é considerada transiente não tendo sido identificada, sendo os recombinantes obtidos diretamente a partir do heterocário. Este processo tem sido denominado de parameiose (Bonatelli Jr et al., 1983; Bagagli et al., 1991). A parameiose foi descrita em muitas espécies de fungos como Acremonium chrysogenum (Ball \& Hamlyn, 1978), Cephalosporium acremonium (Ball \& Hamlyn, 1982), A. niger (Bonatelli Jr et al., 1983) Metarhizium anisopliae (Bagagli et al., 1991), Cladosporum fulvum (Arnau \& Oliver, 1993), T. pseudokoningii (Nadalini, 1997), Beauveria bassiana (Paccola-Meirelles \& Azevedo, 1991; Bello \& PaccolaMeirelles, 1998) entre outras. 
Existem inúmeras descrições da obtenção de recombinantes em muitas espécies de fungos, via processos diferentes daqueles descritos para o ciclo sexual e parassexual de recombinação, onde se observou a ocorrência da transferência, entre núcleos, de transposons, plasmídios, fragmentos cromossômicos e até cromossomos inteiros em heterocários estáveis ou transientes (Caten, 1981; Debets, 1998; Day, 1998).

Caten (1981), em sua revisão sobre os processos parassexuais em fungos, descreveu a ocorrência de processos não - tradicionais de recombinação, sendo considerados três destes processos: recombinação semelhante à meiose, transferência não recíproca de um único gene específico e transferência cromossômica. A recombinação semelhante à meiose foi primeiramente descrita em dicários e cruzamentos em Schizophyllum commune (Parag, 1962; Ellingboe, 1964). Frankel (1979) analisou monocários desenvolvidos a partir do plaqueamento de macerados de três dicários contendo marcadores diferentes. Não foram recuperados diplóides ou aneuplóides, no entanto $28 \%$ das colônias monocarióticas haplóides isoladas possuíam genótipos não-parentais. Estes incluíam recombinantes inter e intracromossomais, sendo que as freqüências de recombinantes intracromossomais eram semelhantes às freqüências meióticas. Portanto este processo parassexual possui altas freqüências de “crossing-over" e redução direta típica da meiose, ao contrário da manutenção dos grupos de ligação e haploidização casual típica do ciclo parassexual (Caten, 1981).

Ellingboe (1963) descreveu um cruzamento em Schizophyllum commune onde somente os fatores de reação sexual ("mating type") foram recombinados, portanto o processo parecia envolver a transferência internuclear de genes individualizados (transferência de fatores específicos). Um caso semelhante foi descrito também em $S$. commune, mas não envolvendo o fator de reação sexual, onde dicários heteroalélicos para uma mutação recessiva $m n d$, produziram setores os quais eram homoalélicos para o alelo mutante mnd (Leonard et al., 1978 a e b). Portanto não ocorreu uma distribuição dos alelos ao acaso como esperado no caso de ciclo parassexual ou uma distribuição semelhante às proporções meióticas, como no caso das recombinações semelhantes à meiose. No entanto, a resolução dos dicários obtida via cruzamentos, resultou somente na formação de monocários contendo genótipos parentais, embora ambos genótipos 
parentais contivessem o alelo mutante mnd. Não foi observada a transformação recíproca dos núcleos $m n d$ em $m n d^{+}$. Observou-se também que o alelo no núcleo transformado se comporta como um gene cromossomal normal em cruzamentos sexuais. Leonard et al. (1978b) concluíram que estaria ocorrendo um novo processo de recombinação somática, envolvendo a transferência internuclear não-recíproca do alelo mnd. Outros resultados, utilizando marcas de auxotrofia ligadas ao alelo mutante $m n d$, sugeriram que este processo envolve a transferência de um segmento cromossômico inteiro (Caten, 1981).

Day (1978 e 1998) descreveu a ocorrência de transferência genética restrita em células conjugantes de Ustilago violaceae. Estas células conjugantes são encontradas em micélios dicarióticos, onde são observadas as formações de tubos conjugativos entre células. Inoculando as células conjugativas, contendo mutações auxotróficas complementares, em meio mínimo, produz-se em adição aos diplóides normais, colônias prototróficas, as quais contêm somente um alelo para reação sexual, sendo, portanto diplóides parciais (Day \& Jones, 1968). Estes diplóides parciais não eram aneuplóides convencionais, visto que quando crescidos em condições não seletivas, estes revertiam para os genótipos parentais, não sendo identificado nenhum recombinante. Os marcadores ligados foram sempre adquiridos e perdidos conjuntamente, e os marcadores localizados em dois ou mais cromossomos podiam ser adquiridos simultaneamente, embora em uma freqüência reduzida. Nos casos onde os marcadores localizados em diferentes cromossomos foram co-adquiridos desta forma, estes foram também sempre perdidos como um grupo. Day (1978 e 1998) interpretou estas observações propondo que estariam ocorrendo quebras ou desintegrações de um dos núcleos parentais no dicário, seguido da aquisição pelos outros núcleos parentais (recipientes) de um ou mais dos cromossomos inteiros liberados, via introdução direta ou na forma de um micronúcleo associado. Em ambos os casos, os cromossomos adquiridos não se misturavam aleatoriamente no genoma recipiente, como em um aneuplóide convencional, mas eram organizados separadamente de tal forma que estes eram perdidos como um todo, da mesma forma como adquiridos. 
Existem muitas descrições da transferência horizontal de genes via anastomose de hifas em isolados oriundos de heterocários incompatíveis entre linhagens de muitas espécies de fungos (Caten, 1972; Anagnostakis, 1983; Collins \& Saville, 1990; Griffiths et al., 1990; Debets et al, 1994; Kempkem, 1995; Debets, 1998). Esta transferência horizontal fornece uma rota alternativa para a transferência de elementos genéticos, como os transposons, e de material genético citoplasmático como DNA mitocondrial, plasmídios e vírus (Debets, 1998). Kinsey (1990) descreveu a transposição de um elemento do tipo LINE, denominado Tad, entre núcleos em um heterocário de Neurospora crassa. Em heterocários normais de $N$. crassa, os núcleos não se fundem, não tendo sido descrito a ocorrência de processos parassexuais nesta espécie. Sendo assim a transposição entre os núcleos foi sugerida como explicação para os resultados obtidos. Kinsey (1993) demonstrou que esta transposição ocorre via um RNA intermediário. Verdoes et al. (1994) descreveram a transferência horizontal entre núcleos, do plasmídio AR (o qual contém a sequiência AMA1 que confere replicação autônoma) sem a ocorrência de recombinações parassexuais. Sugeriu-se que esta transferência poderia ocorrer após um contato transiente entre os núcleos (Debets, 1998). Aleksenko \& Clutterbuck (1995) descreveram a transferência entre núcleos no heterocário de A. nidulans, de um plasmídio de replicação autônoma, na freqüência aproximada de $4 \times 10^{-5}$.

A transferência horizontal de genes, mesmo ocorrendo em baixas freqüências, pode ter consequiências importantes na genética e evolução das populações fúngicas, por permitir a transmissão de elementos "parasitas", como vírus, transposons e plasmídios, e de genes nucleares e mitocondriais (Debets, 1998).

No gênero Trichoderma existem algumas descrições da obtenção de recombinantes diretamente a partir de heterocários onde, devido o padrão de recombinantes obtidos, tem se sugerido a ocorrência de transferência de material genético entre os núcleos no heterocário (Pe'er \& Chet, 1990; Stasz \& Harman, 1990; Bagagli et al., 1995). Stasz \& Harman (1990) propuseram com base nos resultados obtidos a partir de heterocários, dentro e entre várias espécies de Trichoderma, a ocorrência de degradação dos núcleos de um dos parentais envolvidos (parental não 
prevalente) com a incorporação de pequenos fragmentos cromossômicos no genoma dos núcleos do parental prevalecente. Este fato proporcionaria a obtenção de recombinantes como observada pelos autores, isto é, com a maioria das características de somente um dos parentais envolvidos na formação do heterocário, no caso o parental prevalecente.

\subsubsection{Anastomose de hifas: incompatibilidade vegetativa e observações citológicas}

Os fungos filamentosos crescem como uma rede multicelular e multinucleada de células com formato filamentoso denominadas hifas. Um fungo individualizado pode ser visto como um sistema fluído e dinâmico, o qual é caracterizado pelo crescimento por extensão das pontas das hifas, ramificações e fusão de hifas (anastomoses) (Glass et al., 2000). As anastomoses de hifas são importantes por permitirem comunicações entre os compartimentos das hifas e na homeostase. Podem ocorrer fusões de hifas entre indivíduos diferentes formando assim um heterocário, onde núcleos geneticamente diferentes coexistem em um citoplasma comum (Glass et al., 2000). A formação de heterocário é um pré-requisito para a ocorrência dos processos sexuais e parassexuais de recombinação em fungos além de permitir uma cooperação fisiológica para a exploração dos recursos ambientais (Debets, 1998; Glass et al., 2000). Embora existam benefícios para os fungos filamentosos em formar heterocários, existe um mecanismo genético o qual restringe a formação de heterocários entre indivíduos geneticamente diferentes. Este mecanismo é denominado de incompatibilidade vegetativa ou somática ou ainda de incompatibilidade de heterocário e ocorre na maioria das espécies de fungos (senão em todas) (Debets, 1998). A incompatibilidade vegetativa acontece em heterocários entre indivíduos que diferem em um ou mais loci het (incompatibilidade de heterocário). Duas linhagens são ditas compatíveis quando apresentam os mesmos alelos em todos os loci het (Perkins, 1988). A incompatibilidade somática em fungos pode ser manifestada de

várias formas, mas geralmente resulta na inabilidade de se formar um heterocário estável. A incompatibilidade resulta na compartimentalização das células heterocarióticas fusionadas, as quais sofrem um processo lítico que leva à morte celular (Leslie, 1993). A incompatibilidade vegetativa reduz os riscos da transmissão de 
elementos infecciosos citoplasmáticos, tal como vírus de dsRNA (Debets et al., 1994), e a transmissão de genótipos agressivos (Debets, 1998).

Muitos estudos têm sido realizados no sentido de se entender melhor o mecanismo de ocorrência das anastomoses de hifas em muitas espécies de fungos, tanto entre linhagens compatíveis, com a formação de heterocários estáveis, como entre linhagens apresentando incompatibilidade vegetativa, com a formação de heterocários residuais a instáveis (Aimi et al., 2002; Arias et al., 1997; Gómez et al., 1997; Jacobson et al., 1998; Newton et al., 1998; Primo et al., 2001 e Rayner, 1991). Em todos os casos descritos de incompatibilidade vegetativa onde foram realizados estudos citológicos das células heterocarióticas fusionadas, observou-se a ocorrência em vários níveis, de processos líticos levando à morte celular (Aimi et al., 2002; Gómez et al., 1997; Jacobson et al., 1998; Rayner, 1991).

Mecanicamente a anastomose de hifas tem sido dividida em três estágios fisiológicos: pré-contato, pós-contato, e pós-fusão (Glass et al., 2000). As hifas nas regiões periféricas da colônia exibem autotropismo negativo, ou repulsão, a qual mantém uma distância entre as pontas das hifas em crescimento (Prosser, 1994). O mecanismo de repulsão não está claro, embora existam sugestões de ocorrer uma resposta negativa ao acúmulo de metabólitos e um quimotropismo positivo em relação aos maiores níveis de oxigênio (Glass et al., 2000). Atrás das margens das colônias em crescimento, as hifas exibem autotropismo positivo ou atração das pontas das hifas, ocorrendo freqüentes anastomoses (Mccabe et al., 1999). O início do pré-contato das pontas novas das hifas, também denominadas de grampos e o redirecionamento do crescimento da hifa é provavelmente devido a uma difusão de sinais químicos (Glass et al., 2000). As pontas das hifas apresentam uma parada de crescimento após o contato físico, antes da fusão de hifas. Existem tanto aspectos temporais como espaciais do evento de fusão: inicialmente ocorre uma degeneração das paredes celulares, provavelmente devido à uma liberação de enzimas hidrolíticas ao ponto de contato, e então é formada uma ponte de parede celular entre as duas hifas envolvidas, presumivelmente pela liberação de material de parede celular nesta área (Glass et al., 
2000). Os eventos pós-contato de fusão de hifas envolvem a fusão das membranas plasmáticas e a mistura de citoplasmas (Jacobson et al., 1998).

As espécies de fungos diferem na extensão pela qual o heterocário resultante prolifera, tendo sido descritos dois tipos principais. No primeiro tipo, em espécies como Verticillium dahliae (Puhalla \& Mayfield, 1974) e Gibberella fujikuori (Puhalla \& Speith, 1985), os heterocários se limitam somente às células envolvidas nas fusões, não ocorrendo migrações nucleares entre as mesmas. Os heterocários são continuamente refeitos por repetidos eventos de fusão dentro do micélio. No segundo tipo, em espécies como $N$. crassa e Podospora anserina, as células heterocarióticas proliferam e quase todas as células dentro do micélio são heterocarióticas (Glass et al., 2000).

A fusão de hifas entre linhagens geneticamente diferentes na maioria das vezes resulta na incompatibilidade vegetativa devido a diferenças nos loci het. Além das diferenças em como as células heterocarióticas proliferam, existem diferenças na maneira pela qual ocorre a incompatibilidade vegetativa entre as diferentes espécies de fungos (Glass \& Kuldau, 1992 e Leslie, 1993). Em algumas espécies as linhagens envolvidas não formam um heterocário viável, ou é observada na região de contato entre linhagens incompatíveis uma zona "barragem" constituída de segmentos mortos de hifas (Leslie, 1993).

Têm sido descritos em algumas espécies de fungos, estudos de microscopia e ultra-estrutura, associados à incompatibilidade vegetativa (Aimi et al., 2002; Garnjobst \& Wilson, 1956; Gómez et al., 1997; Jacobson et al., 1998; Mylyk, 1976 e Newhouse \& MacDonald, 1991). Jacobson et al. (1998) estudaram a incompatibilidade vegetativa em diplóides parciais heterozigotos para os loci het em $N$. crassa. Linhagens de $N$. crassa diplóides heterozigotas para um único gene de incompatibilidade de heterocário (het) são viáveis, mas apresentam um crescimento muito reduzido e morfologia e pigmentação anormais. Foram examinadas microscopicamente linhagens heterozigotas para o gene het-6 e het-c com o objetivo de se evidenciar o processo de morte celular. Aproximadamente $15 \%$ das células distribuídas aleatoriamente na colônia estavam mortas ou em processo de morte celular. A microscopia eletrônica revelou uma extensiva degradação de organelas e plasmólise. Por fim o citoplasma se fragmentava 
em pequenas vesículas envolvidas por membrana plasmática. Observou-se também um re-crescimento dentro das hifas mortas de células saudáveis adjacentes e que isto era um processo comum. Devido o re-crescimento celular se iniciar logo após o início da degradação celular, foi possível se visualizar restos de organelas em torno da nova célula em crescimento. Em ambos os loci het analisados a heterozigose resultou nos mesmos padrões de morte celular. As mudanças ultra-estruturais nas células em processo de morte foram consistentes com as descrições de apoptose em plantas e animais. Gómez et al. (1997) estudaram a reação de incompatibilidade vegetativa entre isolados de $T$. harzianum pertencentes a diferentes grupos de compatibilidade. Foi possível observar uma região clara, sem a ocorrência de micélio aéreo, na borda entre as duas colônias. Esta área foi descrita como uma zona de lise. Nestas regiões de interação, nas interações incompatíveis, não foi observado nenhum ponto de contato e fusão celular. No entanto o colapso de membranas era comum. O colapso de membranas foi considerado como conseqüência da antibiose. Nas interações compatíveis analisadas, foi possível observar com freqüência a fusão de hifas em vários pontos, não sendo observado processos de morte celular após as fusões celulares.

Em geral existem características comuns nas reações devido às interações de incompatibilidade, estudadas em várias espécies de fungos (Glass et al., 2000). Estas incluem o bloqueio ou tamponamento dos septos, presumivelmente para compartimentalizar os segmentos da hifa em processo de morte, vacuolização do citoplasma, degradação de organelas e deslocamento da membrana plasmática a partir da parede celular. Estas mudanças estruturais das células em processo de morte são consistentes com as características associadas com a morte celular programada (PCD) em eucariontes multicelulares (Glass et al., 2000). A fragmentação do DNA, uma característica do início da PCD, também foi observada em ensaios de TUNEL (desoxirribonucleotidil transferase terminal) em transformantes incompatíveis e em heterocários (Marek et al., 1998). Outras características bioquímicas foram correlacionadas com a reação de incompatibilidade, estas incluem um decréscimo na produção de RNA, aparecimento de novas proteínas, e o aumento na atividade 
proteolítica e de outras enzimas como as fenoloxidases, desidrogenases, proteases e aminoácido oxidases (Boucherie \& Bernet, 1978; Labarère et al., 1974).

As similaridades dos fenótipos de incompatibilidade vegetativa entre diferentes interações het e entre diferentes espécies de fungos, sugerem que os passos mediando as manifestações morfológicas de incompatibilidade vegetativa podem possuir características genéticas e bioquímicas comuns (Glass et al., 2000).

Mesmo tendo sido caracterizados um número de loci het, ainda não é possível propor um modelo completo para as interações entre os produtos dos genes het as quais mediam a incompatibilidade vegetativa. Os loci het codificam produtos gênicos muito diferentes, embora um mecanismo comum da formação de heterocomplexos entre polipeptídeos het alternativos pode mediar o reconhecimento. As análises genéticas e moleculares comparativas dos loci het em diferentes espécies irão fornecer respostas para estas questões (Glass et al., 2000).

\subsubsection{Estudos da recombinação somática ou vegetativa no gênero Trichoderma.}

Devido o potencial de utilização das espécies do gênero Trichoderma para as mais diversas áreas descritas anteriormente, se faz necessário a obtenção de linhagens superiores, no sentido destas apresentarem características adequadas para sua utilização a nível comercial ou industrial. A maioria das linhagens disponíveis atualmente foi obtida pela seleção a partir das populações naturais existentes. Sendo algumas submetidas a processos de mutação - seleção (Stasz et al., 1988).

Na maioria das espécies de Trichoderma não foram encontrados estágios sexuais associados, sendo as espécies consideradas como fungos clonais estritamente mitóticos (Samuels, 1996). No entanto sabe-se que existem formas sexuais ditas teleomórficas, sendo a maioria destas do gênero Hypocrea e gêneros relacionados, membros dos ascomicetos, ordem Hypocreales (Samuels, 1996).

Não foi observada a formação de peritécio de Hypocrea em culturas de linhagens de Trichoderma isoladas a partir de substratos naturais. No entanto, formas anamórficas de Trichoderma se desenvolvem ocasionalmente em culturas derivadas a partir de 
ascósporos de Hypocrea (Samuels, 1996). Questiona-se se as linhagens isoladas de Trichoderma, encontradas na ausência de uma forma teleomórfica, são partes do ciclo de vida de Hypocrea. Algumas das espécies dos agregados de Trichoderma descritos por Rifai (1969), são espécies de Hypocrea no sentido de que são originadas de ascósporos isolados de espécies de Hypocrea. O fungo T. pseudokoningii foi originalmente isolado a partir de ascósporos de Hypocrea schweinitzii no oeste da Austrália (Leuchtmann, 1996).

Alguns autores têm descrito a obtenção de recombinantes de Trichoderma a partir de heterocários provenientes da anastomose de hifas ou da fusão de protoplastos ou ainda pela transferência nuclear entre linhagens de várias espécies, sendo estes cruzamentos tanto intraespecíficos (intra-linhagen ou entre linhagens) como interespecíficos (Bagagli et al., 1995; Furlaneto \& Pizzirani-Kleiner, 1992; Pecchia \& Anné, 1989; Pe’er \& Chet, 1990; Silva \& Pizzirani-Kleiner, 1999; Sivan et al., 1990; Stasz et al., 1988; Stasz et al., 1989 e Stasz \& Harman, 1990).

Estes processos de recombinação somática (ou mitótica) têm sido utilizados em muitas espécies de Trichoderma com o objetivo de se obter linhagens superiores (Pe`er \& Chet, 1990; Samuels, 1996).

$\mathrm{Na}$ maioria dos experimentos realizados com o objetivo de se obter genótipos recombinantes entre linhagens contrastantes de Trichoderma, tem sido observado a ocorrência de padrões característicos, principalmente nos cruzamentos entre linhagens diferentes de uma dada espécie de Trichoderma ou entre espécies diferentes. Estes padrões têm sido referidos como devido algum nível de incompatibilidade vegetativa ou também referido como compatibilidade vegetativa limitada (Bagagli et al., 1995; Silva \& Pizzirani-Kleiner, 1999; Stasz et al., 1989; Stasz \& Harman, 1990;). Estes cruzamentos são caracterizados pela obtenção de recombinantes instáveis, os quais apresentam a maioria dos marcadores envolvidos no cruzamento, semelhante a somente um dos parentais, sendo que estes recombinantes geralmente apresentam bordas irregulares de crescimento e freqüentemente dão origem a setores de crescimento mais vigoroso (Stasz \& Harman, 1990). 
Pe'er \& Chet (1990) realizaram fusões de protoplastos entre linhagens de $T$. harzianum contendo uma marca de auxotrofia e um marcador morfológico contrastante. Eles obtiveram colônias heterocarióticas em meio mínimo na freqüência de 5\%, sendo inoculadas suspensões de conídios a partir destes heterocários e as colônias monospóricas obtidas analisadas. A maioria das colônias obtida era do tipo parental, foram também obtidas colônias recombinantes prototróficas das quais algumas eram instáveis, revertendo para os genótipos parentais, e outras eram estáveis. Os autores sugeriram a ocorrência da transferência no heterocário de parte do genoma de um núcleo doador para um núcleo receptor.

Pecchia \& Anné (1989) realizaram fusões de protoplastos entre isolados de $T$. harzianum. Observou-se a formação de colônias heterocarióticas em meio seletivo, sendo produzidos conídios de ambos parentais. Todas as colônias obtidas a partir das fusões cresciam mais lentamente do que os parentais originais. Não foi observada a formação de colônias diplóides heterozigóticas. Foram isolados a partir dos heterocários colônias morfologicamente diferentes dos parentais, mas estas, na esporulação, originavam colônias com fenótipos parentais. Os autores concluíram que poderia estar ocorrendo algum tipo de incompatibilidade citoplasmática.

Furlaneto \& Pizzirani-Kleiner (1992) obtiveram heterocários de $T$. pseudokoningii via anastomose de hifas e fusão de protoplastos entre linhagens contendo marcadores auxotróficos e morfológicos contrastantes. Algumas colônias heterocarióticas originaram setores, sendo que a maioria destes possuíam os marcadores genéticos de um dos parentais. Obteve-se a partir dos heterocários alguns setores recombinantes. Foram também obtidas colônias recombinantes, em meios seletivos, diretamente a partir de suspensões de conídios oriundas dos heterocários. Os autores encontraram uma alta freqüência de recombinantes, sendo sugerido a ocorrência de processos parassexuais de recombinação.

Bagagli et al. (1995) obtiveram heterocários, via anastomose de hifas, em $T$. pseudokoningii usando linhagens contrastantes para marcadores morfológicos e de auxotrofia. Eles obtiveram colônias monospóricas recombinantes, a partir dos heterocários, as quais apresentaram a maioria dos marcadores de auxotrofia de somente 
um dos parentais. As freqüências de recombinação obtidas foram maiores do que aquelas encontradas em fungos apresentando o ciclo parassexual típico. Os autores propuseram para explicar os resultados obtidos a ocorrência de degradação nuclear dos núcleos de um dos parentais envolvidos, com a incorporação de segmentos cromossômicos nos núcleos prevalecentes do outro parental podendo ocasionar possíveis rearranjos intracromossomais com o envolvimento de DNA citoplasmático, como sugerido originalmente por Stasz \& Harman (1990). Porém não foi descartada a hipótese da ocorrência da parameiose com a existência de um diplóide transiente instável com as sucessivas perdas cromossomais nas mitoses.

Sivan et al. (1990) isolaram núcleos de um mutante auxotrófico de T. harzianum e introduziram em protoplastos de outro mutante auxotrófico da mesma linhagem (transferência intra-linhagem). Foram também isolados núcleos de uma linhagem selvagem prototrófica e introduzidos em uma outra linhagem mutante auxotrófica (transferência entre-linhagem). A transferência intra-linhagem originou uma progênie heterocariótica balanceada, onde os núcleos se segregavam através da conidiogênese, originando ambos parentais auxotróficos em igual número. A transferência entrelinhagem requisitou uma proporção de núcleos para o número de protoplastos recipientes muito superior àquela requerida pela transferência intra-linhagem (100:1 comparado com 10:1, respectivamente). Na transferência entre-linhagem obteve-se uma colônia recombinante em meio seletivo a qual apresentava um crescimento muito lento. Sub-cultivos desta colônia também apresentaram um crescimento lento. O padrão isoenzimático deste recombinante e de seus sub-cultivos era igual a um dos parentais envolvidos na fusão. Foi obtida uma suspensão de esporos desta colônia, e as colônias monospóricas obtidas apresentaram uma taxa de crescimento superior à colônia original. Estas colônias monospóricas diferiram em morfologia a ambos os parentais, mas o padrão isoenzimático foi idêntico a somente um dos parentais. A maioria destas colônias monospóricas era instável e freqüentemente originava setores de crescimento vigoroso. Os autores sugeriram que as transferências nucleares originaram uma instabilidade genética e que tomando os resultados como um todo, estes indicam que no heterocário em diferentes tempos, um dos dois tipos nucleares se expressava enquanto o outro 
permanecia quiescente e que esta expressão preferencial mudava com o tempo. No entanto os autores afirmam a necessidade de se estudar o destino dos núcleos transferidos nas células receptoras.

Stasz \& Harman (1990) caracterizaram várias progênies de cruzamentos (fusões de protoplasto) entre e intralinhagens de T. harzianum, T. hamatum, T. koningii e $T$. viride. O objetivo de suas análises era o de verificar qual ou quais mecanismos de recombinação somática estariam ocorrendo (se a parassexualidade ou outros mecanismos).

Quando dois mutantes auxotróficos da mesma linhagem foram fusionados, obteve-se altas frequiências de colônias prototróficas de rápido crescimento. Foram obtidas suspensões de conídios destas colônias e quando estas foram inoculadas em meios seletivos originaram em igual número colônias idênticas aos dois tipos parentais. Assim, as progênies das fusões intra-linhagem pareciam ser heterocários balanceados, não sendo obtida nenhuma evidência de recombinação entre os dois parentais. Foram conduzidos dezesseis diferentes experimentos de fusão entre-linhagens, sendo obtidos resultados muito diferentes, independente se estas fusões eram entre ou dentre espécies. Após as fusões entre-linhagens terem sido realizadas, desenvolveram-se muito lentamente supostos híbridos somáticos, sendo que estes estavam em menor número quando comparados com os híbridos obtidos das fusões intra-linhagem. A maioria era de colônias ditas prototróficas "fracas". Estas colônias de crescimento lento eram instáveis e originavam setores. Estes setores eram instáveis e davam origem a novas progênies. Normalmente os setores eram mais "fortemente" prototróficos e possuíam um crescimento mais rápido que as progênies originais. Os setores originaram uma grande variedade de tipos morfológicos diferentes. A maioria destes tipos morfológicos eram estáveis por sucessivas gerações de crescimento, assim, estes tipos não se originaram como uma consequiência da heterocariose. As análises isoenzimáticas foram conduzidas em mais de mil colônias provenientes dos cruzamentos. Quase todas foram idênticas ao fenótipo isoenzimático de um dos parentais. Poucas progênies, testadas quando possível logo após as fusões, exibiram fenótipos isoenzimáticos de ambos parentais, mas este padrão biparental de bandas foi rapidamente perdido com as sucessivas repicagens. Os 
padrões isoenzimáticos das enzimas multiméricas nunca originaram padrões de bandas indicativos de heterocariose ou heterozigose. Também não foram detectados padrões de bandas indicativos da presença de diplóides heterozigotos ou de recombinantes. Apesar da extrema variação em tipos morfológicos e de marcas de auxotrofia entre as progênies, os padrões isoenzimáticos das progênies foram invariavelmente idênticos a uma ou outra linhagem parental. Os autores concluíram que as fusões de protoplastos realizadas envolvendo várias espécies de Trichoderma originaram um padrão de progênies, as quais não são explicadas por mecanismos parassexuais de recombinação. Os autores sugerem a ocorrência de degradação de núcleos de um dos parentais (parental não prevalente) após as fusões com a incorporação de pequenos segmentos cromossômicos no genoma dos núcleos do outro parental (parental prevalecente). Os autores supõem que tal incorporação de seqüências de DNA codificando para os nutrientes necessários resultaria no crescimento das colônias no meio mínimo. O nível de prototrofia adquirida iria depender do número de eventos de integração e dos sítios de inserção, principalmente nas proximidades de regiões promotoras, das seqüências gênicas desejadas. Tais inserções iriam resultar provavelmente em padrões alterados de morfologia. Os autores sugerem que tais eventos poderiam ocorrer naturalmente após anastomose de hifas ou outros mecanismos de plasmogamia.

Nadalini (1997) realizou quatro cruzamentos via anastomose de hifas entre quatro mutantes (contendo de duas até cinco marcas de auxotrofia) de uma linhagem de T. pseudokoningii. Foram assim obtidos quatro heterocários, os quais apresentaram um rápido crescimento e esporulação. Foram obtidas suspensões de conídios a partir dos heterocários e estas foram inoculadas em meios seletivos e não seletivos. Obteve-se uma alta freqüência de colônias prototróficas, sendo também observado a obtenção de colônias recombinantes auxotróficas diretamente nos meios seletivos. Observou-se uma alta freqüência de recombinantes auxotróficos (entre 60\% e 80\% das colônias obtidas nos meios seletivos), sendo que os recombinantes com menor número de marcas de auxotrofia (uma e duas marcas respectivamente) foram os mais freqüentes. Observou-se que as colônias heterocarióticas e algumas colônias prototróficas possuíam em torno de $20 \%$ de conídios binucleados. A autora afirma com base nos resultados obtidos a 
ocorrência do processo parassexual de recombinação. Considerando-se os 598 recombinantes obtidos, efetuou-se a análise genética calculando-se o valor de ligação entre nove genes envolvidos nos cruzamentos, objetivando-se assim a construção de um mapa genético e conseqüentemente, o estabelecimento dos grupos de ligação na espécie. Foram desta forma identificados cinco grupos de ligação e a possível localização de nove genes. 


\section{MATERIAL E MÉTODOS}

\subsection{Linhagens utilizadas}

\subsubsection{Trichoderma pseudokoningii}

Linhagem selvagem isolada da Reserva Ecológica do CPATU, Belém-PA, pelo Biólogo Aparecido Osdimir Bertolin e identificada pela Profa. Dra. Maria José dos Santos Fernandes, do Departamento de Micologia da Universidade Federal de Pernambuco.

\subsubsection{Linhagens de Trichoderma pseudokoningii}

Foram utilizadas a linhagem selvagem de T. pseudokoningii (item 3.1.1) e 14 linhagens mutantes obtidas a partir desta por Nadalini (1997):

$\begin{array}{llll}\text { Linhagem } & \text { Marcadores } & \text { Linhagem } & \text { Marcadores } \\ 1 & \text { leu lys whi } & 9 & \text { leu lys met } \arg \text { whi } \\ 2 & \text { nic met } \mathrm{n} & 10 & \text { nic met ino g } \\ 3 \text { (selvagem) } & \text { g } & 11 & \text { nic met ino arg g } \\ 4 & \text { leu lys ade whi } & 12 & \text { nic met ino leu g } \\ 5 & \text { leu lys met whi } & 13 & \text { nic met ino arg rib g } \\ 6 & \text { leu lys arg whi } & 14 & \text { nic met ino arg whi } \\ 8 & \text { nic met ino whi } & 15 & \text { leu lys met arg x whi }\end{array}$

* Marcadores de auxotrofia: leu (leucina), lys (lisina), nic (ácido nicotínico), met (metionina), ino (inositol), arg (arginina), rib (riboflavina), g (coloração verde dos conídios), whi (coloração branca dos conídios), x (marca não identificada). 


\subsection{Meios de cultura e soluções}

3.2.1 Meio mínimo - MM - (Pontecorvo et al., 1953)

$\begin{array}{lc}\mathrm{NaNO}_{3} & 6,0 \mathrm{~g} \\ \mathrm{KH}_{2} \mathrm{PO}_{4} & 1,5 \mathrm{~g} \\ \mathrm{KCL} & 0,5 \mathrm{~g} \\ \mathrm{MgSO}_{4} \cdot 7 \mathrm{H} 2 \mathrm{O} & 0,5 \mathrm{~g} \\ \mathrm{FeSO}_{4} & 0,01 \mathrm{~g} \\ \mathrm{ZnSO}_{4} & 0,01 \mathrm{~g} \\ \mathrm{Glicose}^{2} & 10,0 \mathrm{~g} \\ \text { Ágar } & 15,0 \mathrm{~g} \\ \mathrm{H} & \mathrm{O} \\ & 1000 \mathrm{~mL} \\ & \\ \text { O pH foi ajustado para 6,8 com NaOH } 1 \mathrm{~N}\end{array}$

3.2.2 Meio completo - MC - (Pontecorvo et al., 1953)

$\begin{array}{lc}\text { Meio mínimo com adição de: } & \\ \text { Peptona } & 2,0 \mathrm{~g} \\ \text { Extrato de levedura } & 2,0 \mathrm{~g} \\ \text { Caseína hidrolisada } & 1,5 \mathrm{~g} \\ \text { Solução de vitaminas } & 1,0 \mathrm{~mL} \\ \text { Ágar } & 15,0 \mathrm{~g} \\ \text { O pH foi ajustado para } 6,8 \mathrm{com} \mathrm{NaOH} 1 \mathrm{~N} .\end{array}$

3.2.3 Meios mínimo e completo líquido (Pontecorvo et al., 1953)

Preparados segundo itens 3.2.1 e 3.2.2, não sendo acrescentado ágar. 


\subsubsection{Meio mínimo mais 4\% de meio completo - (MM+4\% MC)}

Foram adicionados ao meio mínimo líquido $4 \%$ de meio completo líquido.

\subsubsection{Solução de vitaminas adicionada ao MC.}

Ácido nicotínico

Ácido $p$-aminobenzóico

Biotina

Piridoxina

Riboflavina

Tiamina

Água destilada esterilizada
$100 \mathrm{mg}$

$10 \mathrm{mg}$

$0,2 \mathrm{mg}$

$50 \mathrm{mg}$

$100 \mathrm{mg}$

$50 \mathrm{mg}$

$100 \mathrm{~mL}$

A solução foi aquecida a $100^{\circ} \mathrm{C}$ em banho-maria por 15 minutos e guardada em frasco escuro a $4^{\circ} \mathrm{C}$.

\subsubsection{Suplementos adicionados ao meio mínimo}

Solução estoque $\mathrm{mg} / 100 \mathrm{~mL} \mathrm{H}_{2} \mathrm{O}$

Adenina, guanina, timina, citosina e uracila

500,00

Biotina

4,00

Ác. $p$-aminobenzóico, timina e piridoxina

5,00

Ácido nicotínico e riboflavina

10,00

Alanina, valina, leucina, isoleucina, prolina, fenilanina, triptofano, metionina, glicina, serina, treonina, cisteína, tirosina, asparagina , glutamina, ácido aspártico, ácido glutâmico, lisina, arginina e histidina 1000,00 
Os estoques foram preparados em água destilada esterilizada. As soluções foram aquecidas a $100^{\circ} \mathrm{C}$ em banho-maria por 15 minutos e conservadas em frascos escuros. A quantidade adicionada por placa com $20 \mathrm{~mL}$ de meio de cultura de cada uma das soluções foi de $0,1 \mathrm{~mL}$.

\subsubsection{Solução salina $0,85 \%(\mathrm{p} / \mathrm{v})$}

$\mathrm{NaCl}$

Água destilada
$8,5 \mathrm{~g}$

$1000 \mathrm{~mL}$

Foram distribuídos $9 \mathrm{~mL}$ por frasco, e posteriormente autoclavados.

\subsubsection{Solução de tween 80 0,1\% (v/v)}

Tween 80

Água destilada
$0,1 \mathrm{~mL}$

$1000 \mathrm{~mL}$

Foram distribuídos 2,5mL em tubos de ensaio e autoclavados.

\subsubsection{Solução de desoxicolato de sódio $10 \%(\mathrm{p} / \mathrm{v})$}

Desoxicolato de sódio

Água destilada
$10,0 \mathrm{~g}$

$100,0 \mathrm{~mL}$

A solução foi autoclavada e mantida em refrigerador.

3.2.10 Solução de albumina 5\% (v/v) - (Robinow \& Caten, 1969)

A solução de albumina foi obtida adicionando-se 5\% de clara de ovo "picotada" até homogeneização, à água destilada. Filtrou-se e conservou-se em frasco escuro no refrigerador. 


\subsubsection{Solução de Giemsa}

Diluiu-se uma parte de Giemsa em 66 partes de glicerina a $60^{\circ} \mathrm{C}$ e, após resfriamento, misturou-se 66 partes de metanol. Esta solução foi mantida a temperatura ambiente.

\subsubsection{Solução de $\mathrm{HCl} 1 \mathrm{~N}$}

$\mathrm{HCl}$ concentrado

Água destilada
$82,5 \mathrm{~mL}$

$1000 \mathrm{~mL}$

A solução foi conservada em frasco escuro a temperatura ambiente.

\subsubsection{Fenol (Sambrook et al., 1989)}

O fenol cristalizado (Synth) foi dissolvido em banho-maria a $65^{\circ} \mathrm{C}$ e adicionado um volume de tampão Tris- $\mathrm{HCl}$ 0,5 M pH8,0. A solução foi submetida a agitação em um agitador magnético por 30 minutos a fim de equilibrar o $\mathrm{pH}$. A fase aquosa foi retirada e o procedimento repetido com Tris- $\mathrm{HCl} 0,1 \mathrm{M} \mathrm{pH} \mathrm{8,0} \mathrm{até} \mathrm{o} \mathrm{pH}$ da fase fenólica atingir 8,0 (medido com papel de filtro). Em seguida, removeu-se a fase aquosa e adicionou-se 0,1 volume de Tris- $\mathrm{HCl} 0,1 \mathrm{M}$ pH 8,0. O fenol foi estocado em frasco escuro a $4^{0} \mathrm{C}$.

\subsubsection{Clorofane}

Para o preparo do clorofane misturou-se um volume de fenol com um volume de clorofórmio. 


\subsubsection{Clorofil}

Foram misturados clorofórmio e álcool isoamílico na proporção de 24:1 (v/v).

\subsubsection{NaCl 5M}
$\mathrm{NaCl}$
$29,22 \mathrm{~g}$
$\mathrm{H}_{2} \mathrm{O}$ destilada
$100 \mathrm{~mL}$

A solução foi autoclavada e mantida a $4^{0} \mathrm{C}$.

\subsubsection{NaCl 3M}

$\begin{array}{ll}\mathrm{NaCl} & 5,84 \mathrm{~g} \\ \mathrm{H}_{2} \mathrm{O} & 100 \mathrm{~mL}\end{array}$

A solução foi autoclavada e mantida a $4^{0} \mathrm{C}$.

\subsubsection{Tris-HCl 1M pH 7,6}

Trizma base

$\mathrm{H}_{2} \mathrm{O}$ destilada

$\mathrm{O}$ pH foi ajustado para 7,6 com $\mathrm{HCl}$ concentrado. A solução foi autoclavada e
$121,1 \mathrm{~g}$

$1000 \mathrm{~mL}$ mantida à $4^{0} \mathrm{C}$.

\subsubsection{Tris-HCl 1M pH 8,0}

Trizma base

$\mathrm{H}_{2} \mathrm{O}$ destilada 
$\mathrm{O} \mathrm{pH}$ foi ajustado para $8,0 \mathrm{com} \mathrm{HCl}$ concentrado. A solução foi autoclavada e mantida a $4^{0} \mathrm{C}$.

\title{
3.2.20 Tampão Tris-EDTA (TE)
}

\author{
Tris-HCl 1M pH 7,6 (item 3.2.18) $1 \mathrm{~mL}$ \\ EDTA (item 3.2.25) $\quad 0,2 \mathrm{~mL}$
}

Completou-se o volume para $100 \mathrm{~mL}$ com $\mathrm{H}_{2} \mathrm{O}$ destilada. A solução foi autoclavada e mantida a $4^{0} \mathrm{C}$.

\subsubsection{Tampão de extração de DNA}

$\begin{array}{ll}\text { Tris-HCl 1M pH 8,0 (item 3.2.19) } & 40 \mathrm{~mL} \\ \text { NaCl 5M (item 3. 2.16) } & 10 \mathrm{~mL} \\ \text { EDTA 0,5M pH 8,0 (item 3.2.25) } & 10 \mathrm{~mL} \\ \text { SDS 10\% (item 3.2.26) } & 20 \mathrm{~mL} \\ \mathrm{H}_{2} \mathrm{O} \text { destilada esterilizada } & 120 \mathrm{~mL}\end{array}$

A solução foi preparada no momento do uso.

\subsubsection{Tampão fosfato $0,02 \mathrm{M}$ pH 5,8}

Solução A

$\mathrm{NaH}_{2} \mathrm{PO}_{4} \cdot \mathrm{H}_{2} \mathrm{O}$

$0,2 \mathrm{M}$

Solução B

$\mathrm{Na}_{2} \mathrm{HPO}_{4}$

$0,2 \mathrm{M}$ 
O tampão fosfato foi feito misturando-se a solução A com uma quantidade suficiente da solução B até atingir o pH 5,8.

\subsubsection{Tampão fosfato $0,2 \mathrm{M} \mathrm{pH} 7,0$}

Solução A

$\mathrm{NaH}_{2} \mathrm{PO}_{4}$

Água destilada

Solução B

$\mathrm{Na}_{2} \mathrm{HPO}_{4}$

Água destilada
$27,8 \mathrm{~g}$

$1000 \mathrm{~mL}$

$63,65 \mathrm{~g}$

$1000 \mathrm{~mL}$

Autoclavou-se as soluções e estocou-se a $4^{0} \mathrm{C}$.

Na hora do uso misturou-se 7 partes da solução A com 3 partes da solução B a fim de se ajustar o $\mathrm{pH}$ para 7,0.

\subsubsection{Solução de KCl 0,6M pH 5,8}

Em 500mL da solução A (item 3.2.23) foram dissolvidos $44,73 \mathrm{~g}$ de $\mathrm{KCl}$. Adicionou-se então um volume suficiente da solução B (item 3.2.23) até atingir o pH 5,8 . O volume final foi completado para $1000 \mathrm{~mL}$ com tampão fosfato $0,2 \mathrm{M} \mathrm{pH} 5,8$. A solução foi autoclavada e mantida a $4^{\circ} \mathrm{C}$. 


\title{
3.2.25 Ácido Etilenodinitrilotetracético sal dissódico (EDTA) 0,5M pH 8,0
}

\author{
EDTA \\ $37,22 \mathrm{~g}$ \\ $\mathrm{H}_{2} \mathrm{O}$ \\ $200 \mathrm{~mL}$
}

$\mathrm{O}$ pH foi ajustado para 8,0 com pastilhas de $\mathrm{NaOH}$. A solução foi autoclavada e mantida a $4^{0} \mathrm{C}$. Para o preparo da solução EDTA $50 \mathrm{mM}$, foram feitas diluições apropriadas a partir do estoque EDTA 0,5M.

\subsubsection{Sódio Dodecil Sulfato (SDS) $10 \%(\mathrm{p} / \mathrm{v})$}

SDS

$20 \mathrm{~g}$

$\mathrm{H}_{2} \mathrm{O}$ destilada

$200 \mathrm{~mL}$

A solução foi autoclavada e mantida a $4^{0} \mathrm{C}$.

\subsubsection{Solução de NDS}

EDTA pH 8,0

$10 \mathrm{mM}$

$\mathrm{N}$-laurilsarcosinato de sódio $\mathrm{p} / \mathrm{v}$

$1 \%$

Tris-HCl $(\mathrm{pH} \mathrm{9,5)}$

$10 \mathrm{mM}$

A solução foi autoclavada e mantida a $4^{\circ} \mathrm{C}$.

\subsubsection{Tampão de corrida TBE 10x}

Trizma base $\mathrm{pH} \quad 8,0$

$54 \mathrm{~g}$

$\mathrm{H}_{3} \mathrm{BO}_{3}$

$27,5 \mathrm{~g}$

EDTA

$4,65 \mathrm{~g}$

$\mathrm{H}_{2} \mathrm{O}$

$500 \mathrm{~mL}$ 
A solução foi autoclavada e guardada à temperatura ambiente. No momento do uso foram feitas as diluições apropriadas.

\subsubsection{Tampão de Mc Ilvaine’s pH 5,8}

Solução de ácido cítrico: 21g em 1000mL de água destilada.

Solução de $\mathrm{Na}_{2} \mathrm{HPO}_{4}: 28,39 \mathrm{~g}$ em $1000 \mathrm{~mL}$ de água destilada.

Para a obtenção do tampão, misturou-se $184,25 \mathrm{~mL}$ da solução de ácido cítrico e $315,75 \mathrm{~mL}$ de $\mathrm{Na}_{2} \mathrm{HPO}_{4}$.

\subsubsection{Solução de $\left(\mathrm{NH}_{4}\right)_{2} \mathrm{SO}_{4} 1,2 \mathrm{M}$ pH5,8}

Dissolveu-se 158,4g de $\left(\mathrm{NH}_{4}\right)_{2} \mathrm{SO}_{4}$ em 300mL do tampão Mc Ilvaine's (item 3.2.29). Ajustou-se o pH para 5,8 com a solução de $\mathrm{Na}_{2} \mathrm{HPO}_{4}$ (item 3.2.29) e completouse o volume para 1000mL com o tampão de Mc Ilvaine's. A solução foi autoclavada e mantida a $4^{0} \mathrm{C}$.

\subsubsection{Solução de $\left(\mathrm{NH}_{4}\right)_{2} \mathrm{SO}_{4} 0,6 \mathrm{M}$ pH5,8}

Diluiu-se na proporção 1:1 a solução de $\left(\mathrm{NH}_{4}\right)_{2} \mathrm{SO}_{4}$ 1,2M (item 3.2.30) em tampão Mc Ilvaine's pH5,8 (item 3.2.29).

\subsubsection{Gel de agarose para confecção dos "plugs"}

Agarose LGT A 4018 (Sigma) 1,4g

TBE 0,5x (item 3.2.28) $100 \mathrm{~mL}$ 


\title{
3.2.33 Gel de agarose para eletroforese em campo pulsado
}

\author{
Agarose A-2929 (Sigma) \\ $0,7 \mathrm{~g}$ \\ TBE 0,5x (item 3.2.28) \\ $100 \mathrm{~mL}$
}

\subsubsection{Gel de agarose $(0,8 \%$ e $1,4 \%)$}

Agarose (Invitrogen)

TBE 1X (item 3.2.28)

$$
\begin{aligned}
& 0,8 \mathrm{~g}(0,8 \%) \text { ou } \\
& 1,4 \mathrm{~g}(1,4 \%) \\
& 100 \mathrm{~mL}
\end{aligned}
$$

3.2.35 Solução de brometo de etídio (Sambrook et al., 1989)

Dissolveu-se 1,0 \% de brometo de etídio (p/v) em água destilada. Esta solução foi agitada por várias horas e estocada à temperatura ambiente. No momento do uso foram adicionados à $100 \mathrm{~mL}$ de tampão TBE $(1 \mathrm{x}), 3 \mu 1$ desta solução. Decorridos 15 minutos o gel corado pôde ser observado sob luz U.V.

\subsubsection{Tampão da amostra (6x)}

$\begin{array}{ll}\text { Azul de bromofenol } & 0,25 \mathrm{~g} \\ \text { Ficoll } & 15 \mathrm{~g} \\ \mathrm{H}_{2} \mathrm{O} & 100 \mathrm{~mL} \\ & \\ \text { O tampão foi estocado a } 4^{0} \mathrm{C} . & \end{array}$




\subsection{Esterilização e incubação}

Os meios de cultura e as soluções foram esterilizados em autoclave por 20 minutos a $121^{\circ} \mathrm{C}$ e 1 atmosfera de pressão. A temperatura de incubação foi de $28^{\circ} \mathrm{C}$ em todos os experimentos.

\subsection{Coloração de núcleos pelo método HCL-Giemsa (Tanaka et al., 1979)}

No caso da coloração de conídios, estes foram aderidos a lamínulas com solução de albumina, e estas foram levemente secas em bico de Bunsen. Nos estudos de conidiogênese, foram colocadas membranas de diálise sobre placas contendo meio completo, sendo inoculados sobre as mesmas, conídios das linhagens a serem estudadas. Após períodos determinados as membranas foram retiradas das placas e colocadas sobre lamínulas. Para as colorações dos heterocários, foram colocadas membranas de diálise em torno dos orifícios centrais das placas de Petri (item 3.5.1) e as mesmas retiradas em tempos determinados conforme o desenvolvimento dos heterocários. Utilizou-se para a fixação uma solução de álcool etílico-ácido acético na proporção 3:1, durante 30 minutos, à temperatura ambiente. A hidratação foi feita por tratamentos sucessivos em álcool etílico $95 \%$ por 5 minutos e álcool etílico $70 \%$ por 30 minutos. A hidrólise foi realizada a seguir com ácido clorídrico $1 \mathrm{~N}$ (item 3.2.12) a $60^{\circ} \mathrm{C}$ por 12 minutos. Após este período, as lamínulas foram lavadas três vezes com água destilada e coradas por imersão em solução de Giemsa (item 3.2.11), diluída 1 para 5 com tampão fosfato $0,2 \mathrm{M}$ $\mathrm{pH}$ 7,0 (item 3.2.23), durante 20 a 30 minutos. $\mathrm{O}$ excesso de corante foi retirado por lavagem com o mesmo tampão e as lamínulas foram colocadas em lâminas e observadas em microscópio óptico. 


\subsection{Análise genética}

\subsubsection{Obtenção de heterocários}

Conídios das linhagens mutantes auxotróficas 9 e 12 (item 3.1.2), com requisitos nutricionais e colorações contrastantes, foram colocados em meio mínimo líquido acrescido de $4 \%$ de meio completo líquido (item 3.2.4) para permitir uma germinação inicial dos conídios, estes foram então colocados em um poço central perfurado em uma placa de Petri contendo meio mínimo (item 3.2.1), e incubados a $28^{\circ} \mathrm{C}$. Depois de 7 dias de incubação a $28^{\circ} \mathrm{C}$, observou-se o crescimento das colônias heterocarióticas por sobre o meio mínimo.

\subsubsection{Isolamento das colônias prototróficas e outros recombinantes}

Conídios das colônias heterocarióticas crescidos em meio mínimo (item 3.2.1), foram ressuspendidos em solução tween 80 (item 3.2.8), diluídos em solução salina (item 3.2.7) e semeados em meio completo (item 3.2.2), meio mínimo e meios seletivos para as marcas envolvidas no cruzamento, sempre combinando as marcas de um com outro parental, menos uma.

As colônias prototróficas foram recuperadas em meio mínimo, enquanto que os outros recombinantes, em meios seletivos.

\subsubsection{Análise dos recombinantes}

As colônias crescidas em meios seletivos foram transferidas para placas mestras (26 pontos) com meio completo (item 3.2.2), e incubadas por 5 dias a $28^{\circ} \mathrm{C}$. As colônias foram analisadas em meio mínimo (item 3.2.1), meio mínimo acrescido dos requisitos nutricionais dos parentais e meio mínimo acrescido de todos os requisitos nutricionais envolvidos no cruzamento, exceto aquele sob análise. As avaliações de crescimento foram feitas no $2^{\circ}$ e $3^{\circ}$ dias de incubação, exceto no caso dos recombinantes que 
apresentaram um crescimento muito lento no meio seletivo onde as avaliações se prolongaram por até 7 dias.

A frequiência de recombinantes foi obtida considerando-se o número de cada tipo de recombinante e o número total de colônias analisadas no cruzamento.

\subsection{Obtenção de protoplastos}

Os conídios da linhagem selvagem de T. pseudokoningii e das linhagens mutantes foram inoculados em placas contendo MC (item 3.2.2), e incubados por 7 dias a $28^{\circ} \mathrm{C}$. Após o crescimento, foi feita uma suspensão de conídios (aproximadamente $10^{9}$ conídios/mL) em solução tween 80 (item 3.2.8). Um mL desta suspensão foi adicionado em erlenmeyers de $250 \mathrm{~mL}$ contendo $50 \mathrm{~mL}$ de MC líquido (item 3.2.3), os quais foram colocados sob agitação $(150 \mathrm{rpm})$ por 18 horas a $28^{\circ} \mathrm{C}$. O micélio foi coletado por filtração em funil de Büchner, lavado 2 vezes com $\left(\mathrm{NH}_{4}\right)_{2} \mathrm{SO}_{4} 0,6 \mathrm{M}$ pH 5,8 (item 3.2.31) e o peso do micélio úmido foi determinado. Para cada mg de micélio úmido foram adicionados $20 \mu \mathrm{L}$ de $\left(\mathrm{NH}_{4}\right)_{2} \mathrm{SO}_{4}$ 0,6 M pH 5,8 e adicionado a enzima lítica (NOVOZYM 234, Novo Nordisk) na proporção de 5\% do peso do micélio. Incubou-se por 3 horas sob agitação rotatória $(50 \mathrm{rpm})$ a $28^{\circ} \mathrm{C}$. Após a protoplastização, fez-se a filtração em seringa com lã de vidro e o filtrado foi centrifugado a $4000 \mathrm{rpm}$ por 5 minutos. Descartou-se o sobrenadante e o precipitado foi ressuspenso com $\left(\mathrm{NH}_{4}\right)_{2} \mathrm{SO}_{4}$ $0,6 \mathrm{M} \mathrm{pH} \mathrm{5,8}$. Este procedimento foi repetido por mais 2 vezes, e na última vez o número de protoplastos foi estimado em câmara de Neubauer. Assim os protoplastos foram ressuspensos em quantidades ideais, a fim de se obter no final juntamente com a agarose LGT (1,4 \%) (item 3.2.32), uma concentração de 2 a $4 \times 10^{8}$ protoplastos $/ \mathrm{mL}$.

\subsection{Preparação dos “plugs”" para eletroforese em campo pulsado}

Após os protoplastos serem ressuspensos em $\left(\mathrm{NH}_{4}\right)_{2} \mathrm{SO}_{4}$ 0,6 $\mathrm{M}$ pH 5,8 (item 3.2.31) até a concentração de 2 a $4 \times 10^{8}$ protoplastos/mL (item 3.6), esta suspensão foi mantida em banho-maria a $42^{\circ} \mathrm{C}$. Preparou-se igual volume de solução de agarose LGT 
1,4\% (item 3.2.32) em solução de $\left(\mathrm{NH}_{4}\right)_{2} \mathrm{SO}_{4}$ 0,6M pH 5,8 (item 3.2.31), a qual foi aquecida até sua completa dissolução, e resfriada até $42^{\circ} \mathrm{C}$ sendo mantida em banhomaria. Volumes iguais das duas soluções foram misturados e homogeneizados, sempre em banho-maria. Aplicou-se em molde próprio para o preparo dos "plugs" e estes foram então mantidos em refrigerador por 15 minutos.

Após a solidificação os "plugs" foram cuidadosamente imergidos em tampão NDS (item 3.2.27) contendo proteinase K (enzima proteolítica obtida de Tritirachium album Sigma), na concentração de $1 \mathrm{mg}$ de enzima para cada $\mathrm{mL}$ do tampão. Os "plugs" foram mantidos a $50^{\circ} \mathrm{C}$ por 18 horas. No final deste período, o tampão NDS foi descartado e adicionou-se a solução de EDTA $50 \mathrm{mM}$ pH 8,0 (item 3.2.25) mantendo a $50^{\circ} \mathrm{C}$ por 30 minutos. O EDTA foi substituído e mantido à temperatura ambiente por 30 minutos. Este procedimento foi repetido mais uma vez e então os "plugs" foram estocados em EDTA $50 \mathrm{mM}$ pH 8,0 em refrigerador.

\subsection{Separação de cromossomos de $T$. pseudokoningii, por eletroforese em campo pulsado - PFGE (Nadalini, 1997)}

Para a separação dos cromossomos utilizou-se gel de agarose 0,7 \% (item 3.2.33), em molde próprio para eletroforese em campo pulsado, do equipamento CHEF DRIII (Bio-Rad), que apresenta um campo elétrico uniforme em todos os campos do gel e um ângulo de $120^{\circ}$ de pulsos alternados. Os "plugs" (item 3.7) foram cortados em pedaços pequenos e postos nas canaletas do gel, sendo estas vedadas com agarose para evitar que as amostras flutuassem no tampão da cuba e o gel foi então colocado na cuba do CHEF DRIII já com o tampão TBE 0,5x (2 litros) (item 3.2.28) previamente resfriado. Foi utilizada a seguinte programação: 168 horas o tempo de corrida com pulsos de 18005400 segundos (rampa linear), com temperatura de $12^{\circ} \mathrm{C}$ a 44 volts. 
3.9 Extração de DNA de fungos filamentosos (Raeder \& Broda, 1985)

Para a extração de DNA as linhagens foram crescidas em meio completo líquido (item 3.2.3), por um período de 24 a 30 horas sob agitação $(150 \mathrm{rpm})$ a $37^{0} \mathrm{C}$. Após este período, o micélio foi filtrado em filtro Büchner, lavado em água destilada esterilizada e em seguida pesado. O micélio foi triturado em nitrogênio líquido e distribuído em tubos, sendo que para cada grama de micélio foram adicionados $2,1 \mathrm{~mL}$ de tampão de extração (item 3.2.21). Esta mistura foi incubada por 15 minutos a $65^{\circ} \mathrm{C}$. Após o período de incubação, adicionou-se um volume de fenol (item 3.2.13), misturou-se as fases e centrifugou-se a 1200 rpm por 10' em microcentrífuga. Desprezou-se a fase fenólica e acrescentou-se à fase aquosa um volume de clorofane (item 3.2.14). Misturou-se as fases e centrifugou-se como anteriormente. Desprezou-se a fase fenólica e adicionou-se à fase aquosa um volume de clorofil (item 3.2.15). Misturou-se as fases e centrifugou-se como nos passos anteriores. Após a centrifugação, retirou-se a fase aquosa e adicionou-se $\mathrm{NaCl} 3 \mathrm{M}$ (item 3.2.17) para uma concentração final de 0,3M. Adicionou-se dois volumes de etanol absoluto, resfriado a $-20^{\circ} \mathrm{C}$. Misturou-se vagarosamente até visualisar-se o DNA precipitado. Os tubos de microcentrífuga contendo o DNA precipitado foram submetidos à centrifugação a 12000 rpm por 15'. Após a secagem do DNA à temperatura ambiente, este foi ressuspendido em $200 \mu \mathrm{L}$ de tampão TE (item 3.2.20).

Por fim os DNAs extraídos foram quantificados e sua integridade verificada em gel de agarose $0,8 \%$ (item 3.2.34). A quantificação foi realizada por comparação com concentrações conhecidas de DNA do fago lambda (Life Technologies).

\subsection{Amplificação de DNA por RAPD}

As reações de amplificação foram preparadas para um volume final de $30 \mu \mathrm{L}$, contendo: tampão (Tris- $\mathrm{HCl} 20 \mathrm{mM}$ pH8,4; $\mathrm{KCl} 50 \mathrm{mM}$ ); mistura de nucleotídeos $(0,25 \mathrm{mM})$; primer $(0,4 \mu \mathrm{M}) ; \mathrm{MgCl}_{2}(3,4 \mathrm{mM})$; enzima Taq DNA polimerase (2 unidades) e DNA genômico (15ng). As reações controle consistiram na adição de todos os 
componentes da reação, exceto o DNA genômico. A amplificação foi realizada em um termociclador (Perkin-Elmer - Gene Amp PCR System 9700) programado para realizar uma desnaturação inicial a $94{ }^{\circ} \mathrm{C}$ por 5 minutos, seguida de 40 ciclos de 1 minuto a 92 ${ }^{\circ} \mathrm{C}, 1$ minuto a $35^{\circ} \mathrm{C}, 2$ minutos a $72{ }^{\circ} \mathrm{C}$ e uma extensão final de 5 minutos a $72{ }^{\circ} \mathrm{C}$.

Amostras de $20 \mu \mathrm{L}$ dos produtos de amplificação foram misturadas com aproximadamente $3 \mu \mathrm{L}$ do tampão da amostra (6x) (item 3.2.36) e separados por eletroforese, a $3 \mathrm{~V} \mathrm{~cm}^{-1}$, em gel de agarose a 1,4 \% (item 3.2.34). Como padrão de peso molecular foi utilizado o marcador 100pb DNA Ladder (Invitrogen). Após a eletroforese, o gel de agarose foi corado com brometo de etídio (item 3.2.35), visualizado sobre um transiluminador de luz ultravioleta e fotodocumentado.

\subsection{Reamplificação de bandas isoladas dos géis de RAPD}

Sequiências de DNA amplificadas via RAPD e submetidas à eletroforese em géis de agarose, foram isoladas e reamplificadas. Para isto, estas seqüências amplificadas, visualizadas como bandas nos géis de agarose, foram cortadas dos géis, colocadas em tubos de microcentrífuga e maceradas com o uso de um fio de platina esterilizado. Ao macerado foi adicionado em torno de $200 \mu \mathrm{L}$ de $\mathrm{H}_{2} \mathrm{O}$ " Milli Q" esterilizada. As reações de reamplificação foram feitas utilizando-se os mesmos primers usados no RAPD e $5 \mu \mathrm{L}$ da suspensão de DNA proveniente do macerado, sendo as reações preparadas conforme o item 3.10. As bandas de RAPD reamplificadas foram purificadas com o Kit " Concert - Rapid PCR Purification System/Life Technologies" de acordo com as recomendações do fabricante.

\subsection{Seqüênciamento das bandas de RAPD reamplificadas}

As bandas de RAPD reamplificadas e purificadas (item 3.11), foram clonadas no plasmídio "pGEMT - Easy Vector (Promega)" de acordo com as recomendações do fabricante. A extração do plasmídio com o inserto de interesse foi realizada conforme 
Sambrook et al. (1989). As bandas de RAPD clonadas foram então seqüenciadas no laboratório do Prof. Dr. Ricardo Harekaya (Instituto Biológico - São Paulo). 


\section{RESULTADOS E DISCUSSÃO}

\subsection{Seleção das linhagens para a realização dos cruzamentos}

A seleção das linhagens a serem utilizadas nos cruzamentos foi baseada inicialmente no perfil de bandas de RAPD apresentado pelas 14 linhagens analisadas (item 3.1.2).

Foram testados 97 primers de RAPD. Todas as linhagens apresentaram perfis de bandas de RAPD muito semelhantes. Isto evidencia que as linhagens utilizadas eram todas isogênicas, uma vez que estas eram linhagens mutantes originadas por ciclos de indução de mutação de uma mesma linhagem original, apesar de apresentarem diferentes marcadores de auxotrofia (item 3.1.2) (Nadalini, 1997). No entanto a linhagem 12 apresentou na maioria dos iniciadores utilizados uma ou mais bandas adicionais (Figura $1)$. 
(a)

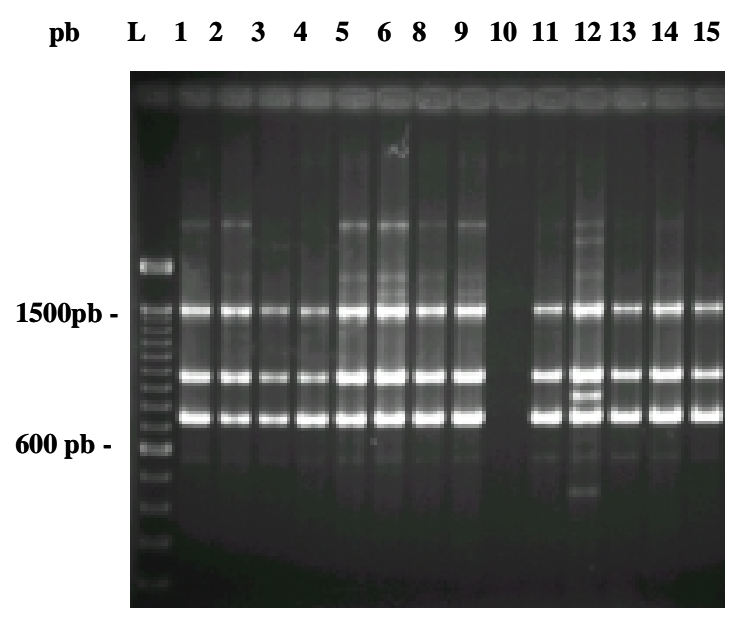

(b)

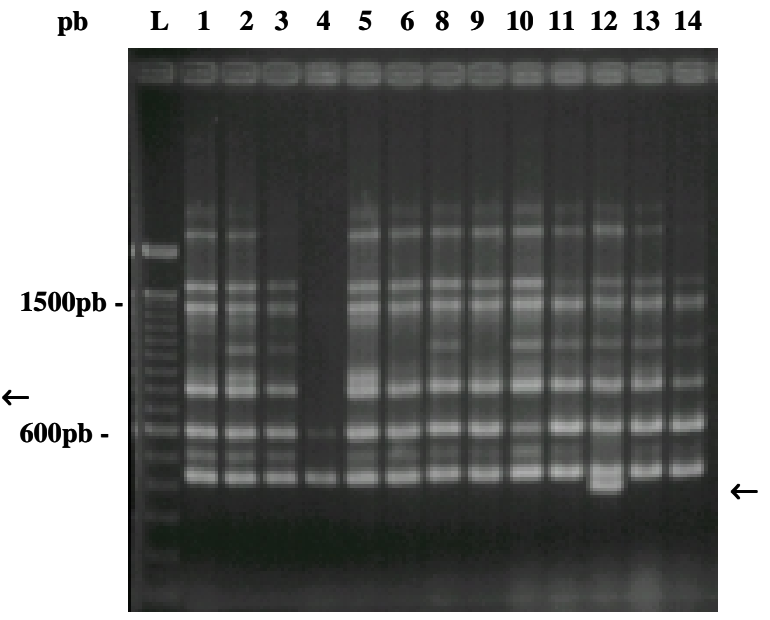

Figura 1- Perfil de bandas de RAPD das linhagens de T. pseudokoningii. A linhagem 12 apresenta uma banda extra (setas), que as demais linhagens não apresentam. Lmarcador de peso molecular (Ladder); (a) primer - P16 , (b) primer - P19. pb - peso molecular das bandas em pares de bases.

Com base no perfil de bandas apresentado selecionou-se a linhagem 9 (conídios brancos) e a linhagem 12 (conídios verdes) para a realização dos cruzamentos (Figura 2). 
(a)

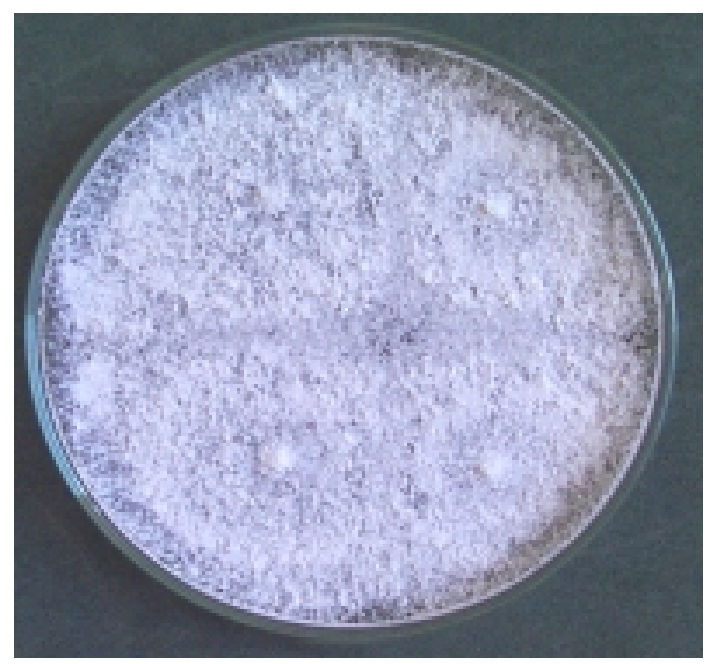

Linhagem 9 (leu lys met arg w) (b)

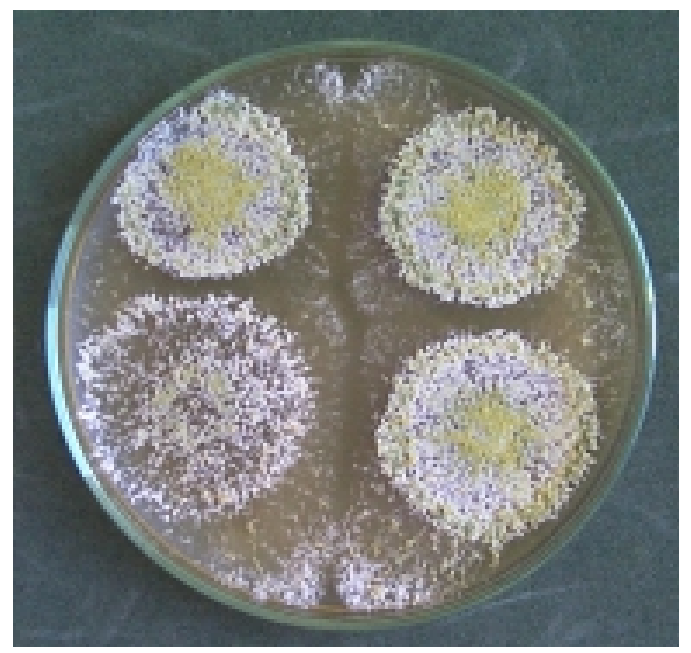

linhagem 12 (nic met ino leu g) ${ }^{*}$

Figura 2 - Linhagens 9 (a) e 12 (b) selecionadas para a realização dos cruzamentos com base no perfil de bandas RAPD, marcadores de auxotrofia e coloração dos conídios.* marcadores de auxotrofia: leu- leucina, lys- lisina, met- metionina, arg- arginina, nic- ácido nicotínico, ino- inositol; marcadores de coloração dos conídios: w- coloração branca, g- coloração verde.

As linhagens 9 e 12 foram então contrastadas com o uso de vários primers. $\mathrm{Na}$ maioria dos primers utilizados a linhagem 12 apresentou uma banda adicional (Figura $3)$. 


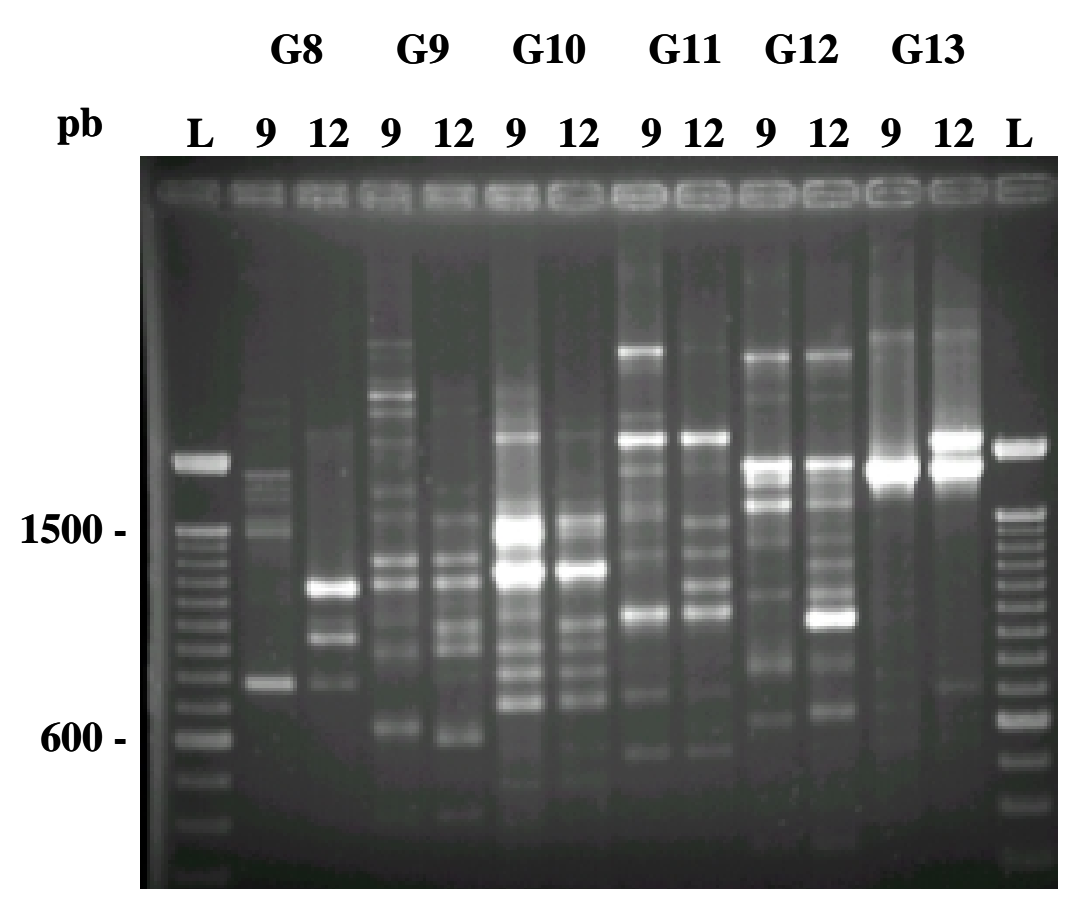

Figura 3 - Contraste no perfil de bandas RAPD entre as linhagens 9 e 12 utilizadas nos cruzamentos. L - Marcador de peso molecular (Ladder); G8 a G13 - primers, $\mathrm{pb}$ - peso molecular do marcador em pares de bases.

\subsection{Cruzamentos por anastomose de hifas}

A realização dos cruzamentos foi conduzida como descrito no item 3.5.1. Foram realizados quatro cruzamentos, independentes um do outro, envolvendo as linhagens 9 e 12 (Tabela 1). As colônias heterocarióticas apresentaram um rápido crescimento (de cinco a sete dias) e intensa esporulação (Figura 4). Nadalini (1997) também obteve colônias heterocarióticas de rápido crescimento e esporulação no meio mínimo, utilizando outras linhagens de T. pseudokoningii. Estes mesmos resultados foram obtidos por Furlaneto \& Pizzirani-Kleiner (1992) utilizando linhagens mutantes de $T$. pseudokoningii.

Foram feitas suspensões de conídios a partir das colônias heterocarióticas e estas foram inoculadas em meios seletivos e não seletivos (item 3.5.2). Os resultados são apresentados na Tabela 1 . 
Tabela 1. Isolamento de colônias parentais e recombinantes a partir de suspensões de conídios obtidas dos heterocários de quatro cruzamentos entre as linhagens 9L e $12 \mathrm{~L}$.

\begin{tabular}{|c|c|c|c|c|c|}
\hline & $\begin{array}{c}1^{0} \text { Heterocário } \\
\text { (MM+leu+met)* }\end{array}$ & $\begin{array}{l}2^{0} \text { Heterocário } \\
\text { (MM+leu+met) }\end{array}$ & $\begin{array}{c}3^{0} \text { Heterocário } \\
\text { (MM) }\end{array}$ & $\begin{array}{l}4^{0} \text { Heterocário } \\
(\mathrm{MM}+\text { leu+met })\end{array}$ & Total \\
\hline Isolamento & Meio completo & Meios seletivos & Meios seletivos & Meios seletivos & \\
\hline \multicolumn{6}{|l|}{ Recombinantes } \\
\hline Prototróficos & 35 & 2 & 1 & 25 & 63 \\
\hline Não prototróficos & 28 & 2 & 1 & 17 & 48 \\
\hline Total & $63(14 \%)$ & $4(2 \%)$ & $2(2 \%)$ & $42(12 \%)$ & $111(10 \%)$ \\
\hline \multicolumn{6}{|l|}{ Parentais } \\
\hline Linhagem 9 & 27 & 196 & 0 & 294 & 517 \\
\hline Linhagem 12 & 348 & 0 & 76 & 0 & 424 \\
\hline Total & $375(85 \%)$ & $196(96 \%)$ & $76(97 \%)$ & $294(87 \%)$ & $941(89 \%)$ \\
\hline Total de col. analisadas & 438 & 200 & 78 & 336 & 1052 \\
\hline
\end{tabular}

*Obs. Os heterocários foram crescidos em MM e MM adicionado das marcas auxotróficas para ambas linhagens parentais $(\mathrm{MM}+\mathrm{leu}+\mathrm{met})$. Marcas: leu - leucina, met - metionina.

Em relação aos meios utilizados no isolamento das colônias a partir do heterocário, verifica-se que o uso de meio completo (MC), no caso do primeiro heterocário, aumentou o número de colônias recuperadas, não tendo sido diminuído proporcionalmente o número de colônias recombinantes obtidas. Já o uso do meio mínimo $(\mathrm{MM})$ para a formação do terceiro heterocário, sem a suplementação de leucina (leu) e metionina (met), os quais são requisitos nutricionais de ambas linhagens parentais envolvidas nos cruzamentos, ocasionou uma diminuição drástica do número de colônias obtidas nos meios seletivos e na proporção de colônias recombinantes obtidas. Nadalini (1997) também verificou uma maior freqüência no isolamento de colônias, com o uso de meio completo, em quatro cruzamentos envolvendo diferentes linhagens de $T$. pseudokoningii, mas a proporção de colônias recombinantes obtidas foi menor quando comparada com o uso dos diferentes meios seletivos. 
(a)

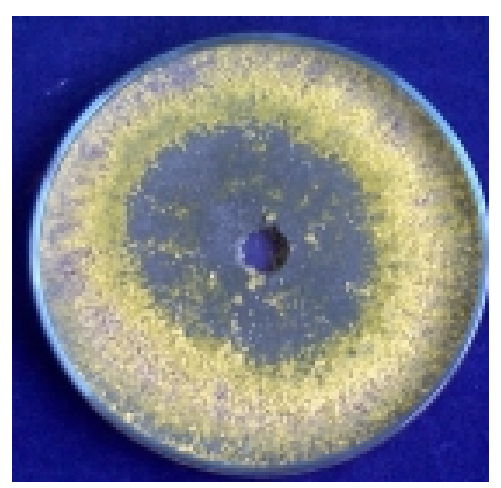

(b)

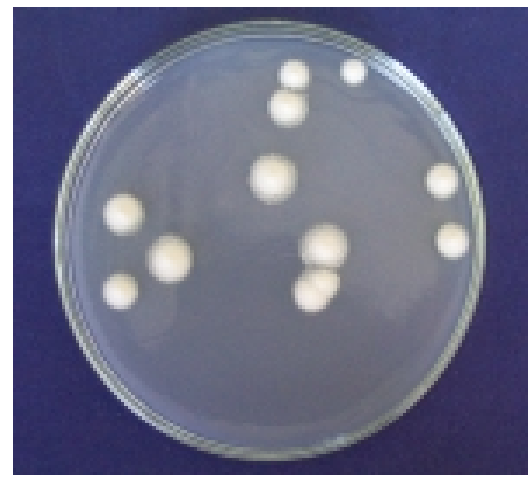

(c)

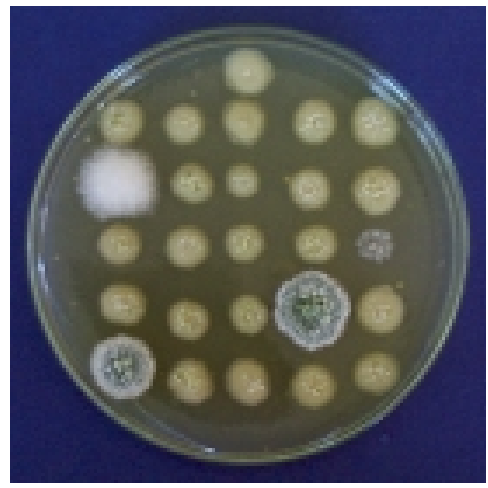

Figura 4 - Etapas do processo de obtenção e análise das colônias recombinantes. (a) colônia heterocariótica (MM+leu+met); (b) obtenção de colônias recombinantes em meio seletivo; (c) placa mestra (meio completo) contendo colônias isoladas a partir dos meios seletivos e não seletivos.

Foram analisadas 1.052 colônias isoladas a partir dos heterocários, sendo encontradas inicialmente um total de 111 colônias recombinantes (10\%) (Tabela 1). Nadalini (1997) obteve uma freqüência de 15\% de colônias recombinantes obtidas dos 4 cruzamentos realizados.

Pode ser observada na Tabela 1, no isolamento das colônias parentais, a prevalência de somente um dos genótipos parentais, sendo que em cada heterocário analisado o parental prevalente foi alternado. Com exceção do primeiro heterocário, a 
prevalência de um dos genótipos parentais foi total, não sendo encontrado nenhuma colônia com genótipo do parental não prevalente.

Para confirmar estes resultados foi feito um novo heterocário e obtida uma suspensão de conídios a partir deste, sendo esta suspensão diluída apropriadamente e inoculada em meio completo (item 3.5.1). As colônias foram avaliadas pela morfologia, anotando-se a proporção de fenótipos de um ou outro parental (Figura 5 e Tabela 2).

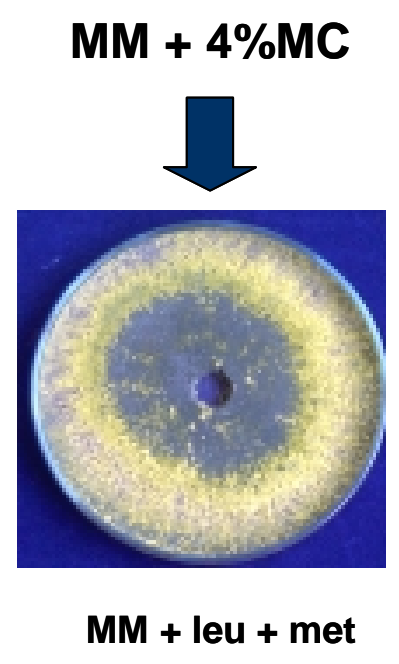

(a)

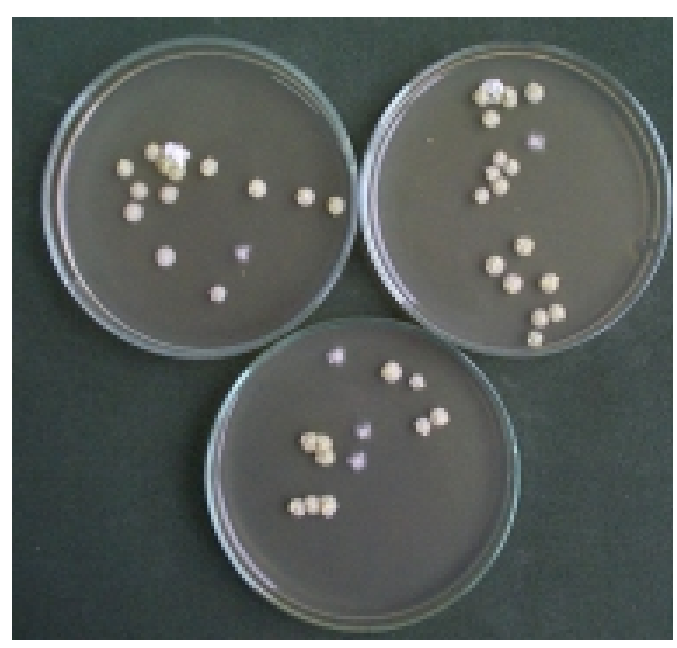

$$
M C+\arg +\text { ino }
$$

(b)

Figura 5 - Proporção de fenótipos parentais das colônias isoladas a partir do heterocário. (a) - estabelecimento do heterocário conforme descrito no item 3.5.1; (b) obtenção de colônias, em meio completo suplementado, a partir de suspensões de conídios obtidas do heterocário. 
Tabela 2. Proporção de fenótipos parentais (9L ou 12L) das colônias isoladas, em meio completo (MC), a partir de suspensões de conídios obtidas dos heterocários.

\begin{tabular}{ccc}
\hline Placa* & Colônias 9L & Colônias 12L \\
\hline 1 & 3 & 10 \\
2 & 1 & 16 \\
3 & 4 & 12 \\
4 & 6 & 16 \\
5 & 1 & 13 \\
Total de col: 82 & $15(18,29 \%)$ & $67(81,71 \%)$ \\
\hline
\end{tabular}

* As suspensões de conídios foram inoculadas em cinco placas de Petri e os fenótipos das colônias obtidas foram avaliados como sendo do tipo parental 9L ou 12L respectivamente (Figura 5).

Verificou-se novamente neste heterocário, sendo agora analisado somente pela morfologia das colônias isoladas, a maior freqüência de genótipos de um dos parentais, no caso o parental $12 \mathrm{~L}$, tendo este uma frequiência em torno de $82 \%$. Neste caso a prevalência do genótipo 12L não foi absoluta como observada em outros heterocários descritos anteriormente.

Furlaneto \& Pizzirani-Kleiner (1992) obtiveram colônias heterocarióticas a partir de fusões de protoplastos entre linhagens de T. pseudokoningii, as quais originaram setores cujas marcas de auxotrofia eram de somente um dos parentais envolvidos no cruzamento. Stasz \& Harman (1990) ao analisarem por isoenzimas um número grande de progênies oriundas de fusões de protoplastos entre linhagens de várias espécies de Trichoderma, verificaram que a maioria destas progênies apresentavam o padrão isoenzimático de somente um dos parentais.

Estes resultados da proporção de genótipos parentais serão discutidos posteriormente junto com os resultados das análises das colônias recombinantes isoladas com o uso dos marcadores RAPD. 
A partir do heterocário descrito anteriormente (Figura 5), foi obtida uma suspensão de conídios e esta inoculada em meios seletivos que somente permitisse o crescimento de colônias de um ou do outro parental envolvidos no cruzamento (Tabela $3)$.

Tabela 3. Crescimento diferenciado em meio seletivo entre as colônias parentais 9L e $12 \mathrm{~L}$.

\begin{tabular}{ccc}
\hline Dias de Crescimento & Meio seletivo para 9L & Meio seletivo para 12L \\
\hline 9 dias & 47 & 23 \\
15 dias & confluente & 52 \\
\hline
\end{tabular}

Obs. Número de colônias obtidas em 9 e 15 dias de crescimento a $28^{\circ} \mathrm{C}$, em 5 placas contendo meios seletivos específicos para o crescimento do parental 9L ou do parental 12L respectivamente, a partir de suspensões de conídios obtidas do heterocário (Figura $5)$.

Observou-se que as colônias crescidas em meio seletivo para o parental 12L possuíam um crescimento muito lento quando comparadas com aquelas crescidas no meio seletivo para o parental 9L. Com nove dias de crescimento as colônias no meio seletivo para o parental 12L apareciam somente como pontos pequenos nas placas, de dois a quatro milímetros (dados não apresentados), enquanto que as colônias no meio seletivo para o parental 9L eram bem maiores e com intensa esporulação. Com quinze dias de crescimento as colônias crescidas no meio seletivo para o parental 9L haviam se misturado (confluente), já no meio seletivo para o parental 12L algumas colônias começavam a esporular e outras apareciam somente como pequenos pontos no meio de cultura.

Nos meios seletivos, muitas colônias recombinantes apresentavam um crescimento muito lento e pouca esporulação (Figura 4), sendo necessário de 15 a 30 dias para se obter colônias de alguns milímetros de diâmetro. Pecchia \& Anné (1989) 
observaram um lento desenvolvimento das progênies de Trichoderma harzianum em meios seletivos. Stasz \& Harman (1990) ao estudarem vários cruzamentos envolvendo diferentes linhagens de diferentes espécies de Trichoderma, também observaram um desenvolvimento muito lento das colônias de Trichoderma recombinantes obtidas nos meios seletivos.

As colônias recombinantes obtidas apresentaram conforme o repique, bordas irregulares de crescimento do micélio e a formação de bordas e setores de crescimento mais vigoroso (Figura 6).

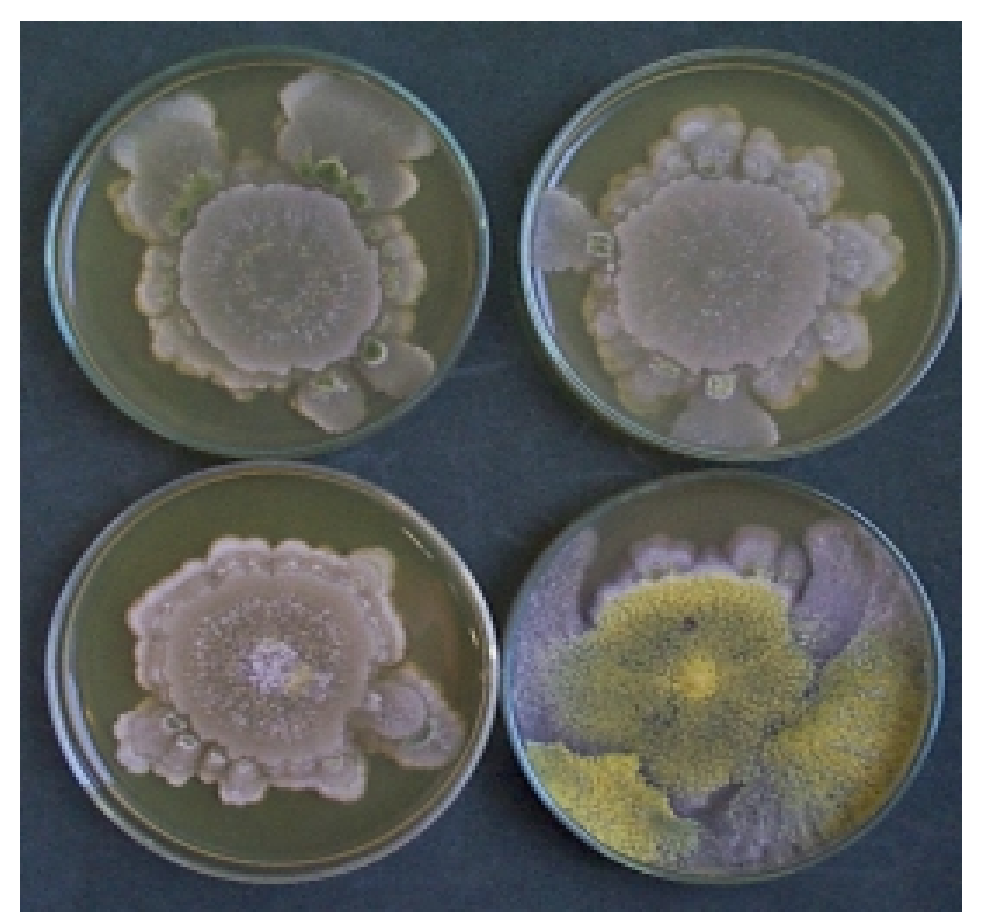

Figura 6 - Colônias recombinantes crescidas em meio completo (MC): colônias apresentando bordas irregulares de crescimento e com a freqüente formação de setores.

Vários estudos descrevendo cruzamentos entre linhagens, dentre e entre diferentes espécies, de Trichoderma, tanto via anastomose de hifas como fusão de protoplastos ou transferência de núcleos isolados em protoplastos, têm descrito a 
obtenção de colônias recombinantes instáveis, de lento crescimento em meios seletivos, e com a freqüente formação de setores (Bagagli et al., 1995; Furlaneto \& PizziraniKleiner, 1992; Pecchia \& Anné, 1989; Stasz et al., 1988; Stasz et al., 1989; Stasz \& Harman, 1990).

Devido ao aspecto instável das colônias inicialmente isoladas (monospóricas), obteve-se novas culturas monospóricas, sendo que estas foram repicadas mais duas gerações. Assim analisou-se as marcas das colônias recombinantes em quatro gerações, sendo duas a partir de culturas monospóricas e duas a partir de repiques. Os resultados são apresentados na Quadro 1.

\begin{tabular}{|c|c|c|c|c|}
\hline Recombinantes & \multicolumn{4}{|c|}{ Marcas/ geração de repique } \\
\hline & $\begin{array}{l}\text { Colônia } \\
\text { original }\end{array}$ & $\begin{array}{c}1^{\mathrm{a}} \text { geração } \\
\text { (monospórica) }\end{array}$ & $\begin{array}{c}2^{\mathrm{a}} \text { geração } \\
\text { (repique) }\end{array}$ & $\begin{array}{c}3^{\mathrm{a}} \text { geração } \\
\text { (repique) }\end{array}$ \\
\hline 1 & $\begin{array}{c}\text { leu lys ino met } \\
\text { arg }\end{array}$ & $\begin{array}{c}\text { leu lys met arg } \\
\text { (9) }\end{array}$ & prototrófico & prototrófico \\
\hline 2 & $\begin{array}{c}\text { leu lys ino met } \\
\text { nic arg }\end{array}$ & leu ino met & leu ino met & leu ino met \\
\hline 3 & leu arg & prototrófico & met & prototrófico \\
\hline 4 & leu met arg & $\begin{array}{c}\text { leu lys met arg } \\
\text { (9) }\end{array}$ & $\begin{array}{c}\text { leu lys met arg } \\
\text { (9) }\end{array}$ & $\begin{array}{c}\text { leu lys met arg } \\
\text { (9) }\end{array}$ \\
\hline 5 & leu met arg & $\begin{array}{l}\text { leu lys met arg } \\
\text { (9) }\end{array}$ & $\begin{array}{c}\text { leu lys met arg } \\
\text { (9) }\end{array}$ & $\begin{array}{c}\text { leu lys met arg } \\
\text { (9) }\end{array}$ \\
\hline 6 & leu met arg & leu ino met & leu ino met & leu ino met \\
\hline 7 & $\begin{array}{c}\text { leu ino met nic } \\
\text { arg }\end{array}$ & $\begin{array}{c}\text { leu lys met arg } \\
\text { (9) }\end{array}$ & $\begin{array}{c}\text { leu lys met arg } \\
\text { (9) }\end{array}$ & $\begin{array}{c}\text { leu lys met arg } \\
\text { (9) }\end{array}$ \\
\hline
\end{tabular}

Quadro 1 - Análise da estabilidade dos marcadores de auxotrofia das colônias recombinantes em quatro gerações de crescimento. 


\begin{tabular}{|c|c|c|c|c|}
\hline 8 & $\begin{array}{c}\text { leu ino met nic } \\
\text { arg }\end{array}$ & leu ino met & leu ino met & leu ino met \\
\hline 9 & leu ino met & leu ino met & leu ino met & leu ino met \\
\hline 10 & lys met arg & $\begin{array}{c}\text { leu lys met arg } \\
\text { (9) }\end{array}$ & $\begin{array}{c}\text { leu lys met arg } \\
\text { (9) }\end{array}$ & $\begin{array}{c}\text { leu lys met arg } \\
\text { (9) }\end{array}$ \\
\hline 11 & leu ino met arg & $\begin{array}{c}\text { leu lys met arg } \\
\text { (9) }\end{array}$ & $\begin{array}{c}\text { leu lys met arg } \\
\text { (9) }\end{array}$ & $\begin{array}{l}\text { leu lys met arg } \\
\text { (9) }\end{array}$ \\
\hline 12 & leu met & leu ino met & leu ino met & leu ino met \\
\hline 13 & leu met & ino met & leu ino met & leu ino met \\
\hline 14 & leu met & Ino & leu ino met & leu ino met \\
\hline 15 & leu lys met & Ino & leu ino met & leu ino met \\
\hline 16 & leu met & ino met & leu ino met & leu ino met \\
\hline 17 & leu met & ino met & leu ino met & leu ino met \\
\hline 18 & leu met & leu ino met & leu ino met & leu ino met \\
\hline 19 & leu met & $\begin{array}{l}\text { leu lys met arg } \\
\text { (9) }\end{array}$ & $\begin{array}{c}\text { leu lys met arg } \\
\text { (9) }\end{array}$ & $\begin{array}{c}\text { leu lys met arg } \\
\text { (9) }\end{array}$ \\
\hline 20 & leu met & leu ino met & leu ino met & leu ino met \\
\hline 21 & leu ino met & leu ino met & leu ino met & leu ino met \\
\hline 22 & prototrófico & ino met & leu ino met & leu ino met \\
\hline 23 & prototrófico & Prototrófico & prototrófico & prototrófico \\
\hline 24 & $\begin{array}{l}\text { leu lys ino met } \\
\text { arg }\end{array}$ & Lys & $\begin{array}{l}\text { leu lys met arg } \\
\text { (9) }\end{array}$ & $\begin{array}{c}\text { leu lys met arg } \\
\text { (9) }\end{array}$ \\
\hline 25 & leu met nic & Leu & leu met & leu met \\
\hline 26 & prototrófico & Ino & leu ino met & leu ino met \\
\hline 27 & $*$ & $*$ & * & * \\
\hline 28 & * & Ino & leu ino met & leu ino met \\
\hline
\end{tabular}

Quadro 1 - Análise da estabilidade dos marcadores de auxotrofia das colônias recombinantes em quatro gerações de crescimento. 


\begin{tabular}{|c|c|c|c|c|}
\hline 29 & * & Prototrófico & prototrófico & prototrófico \\
\hline 30 & prototrófico & Prototrófico & prototrófico & prototrófico \\
\hline 31 & $*$ & ino met & leu ino met & leu ino met \\
\hline 32 & prototrófico & ino met & leu ino met & leu ino met \\
\hline 33 & $*$ & ino met & leu ino met & leu ino met \\
\hline 34 & $\begin{array}{c}\text { leu lys met arg } \\
\text { ino }\end{array}$ & $\begin{array}{c}\text { leu lys met arg } \\
\text { (9) }\end{array}$ & $\begin{array}{c}\text { leu lys met arg } \\
\text { (9) }\end{array}$ & $\begin{array}{c}\text { leu lys met arg } \\
\text { (9) }\end{array}$ \\
\hline 35 & $*$ & leu met & leu ino met & leu ino met \\
\hline 36 & $*$ & leu ino met & leu ino met & leu ino met \\
\hline 37 & prototrófico & leu ino met & leu ino met & leu ino met \\
\hline 38 & prototrófico & leu ino met & leu ino met & leu ino met \\
\hline 39 & prototrófico & ino met & leu ino met & leu ino met \\
\hline 40 & $*$ & lys met arg & $\begin{array}{c}\text { leu lys met arg } \\
\text { (9) }\end{array}$ & $\begin{array}{c}\text { leu lys met arg } \\
\text { (9) }\end{array}$ \\
\hline 41 & prototrófico & ino met & leu ino met & leu ino met \\
\hline 42 & met & ino met & leu ino met & leu ino met \\
\hline 43 & leu lys met ino & leu ino met & leu ino met & leu ino met \\
\hline 44 & leu lys met ino & leu ino met & leu ino met & leu ino met \\
\hline 45 & prototrófico & ino met & leu ino met & leu ino met \\
\hline 46 & $*$ & ino met & leu ino met & leu ino met \\
\hline 47 & prototrófico & leu ino met & leu ino met & leu ino met \\
\hline 48 & prototrófico & leu ino met & leu ino met & leu ino met \\
\hline 49 & prototrófico & leu ino met & leu ino met & leu ino met \\
\hline 50 & prototrófico & leu ino met & leu ino met & leu ino met \\
\hline 51 & prototrófico & leu ino & leu ino met & leu ino met \\
\hline 52 & prototrófico & leu ino & leu ino met & leu ino met \\
\hline
\end{tabular}

Quadro 1 - Análise da estabilidade dos marcadores de auxotrofia das colônias recombinantes em quatro gerações de crescimento. 


\begin{tabular}{|c|c|c|c|c|}
\hline 53 & prototrófico & Ino & leu ino met & leu ino met \\
\hline 54 & prototrófico & leu ino & leu ino met & leu ino met \\
\hline 55 & $*$ & $\begin{array}{l}\text { leu ino met nic } \\
\text { (12) }\end{array}$ & leu ino met & leu ino met \\
\hline 56 & prototrófico & $\begin{array}{l}\text { leu ino met nic } \\
\text { (12) }\end{array}$ & leu ino met & leu ino met \\
\hline 57 & leu lys arg & $\begin{array}{l}\text { leu ino met nic } \\
\text { (12) }\end{array}$ & leu ino met & leu ino met \\
\hline 58 & prototrófico & $\begin{array}{l}\text { leu ino met nic } \\
\text { (12) }\end{array}$ & leu ino met & leu ino met \\
\hline 59 & prototrófico & Prototrófico & prototrófico & prototrófico \\
\hline 60 & prototrófico & ino & leu ino met & leu ino met lys \\
\hline 61 & prototrófico & leu ino & leu ino met & leu ino met \\
\hline 62 & prototrófico & leu ino & leu ino met & leu ino met \\
\hline 63 & prototrófico & prototrófico & prototrófico & prototrófico \\
\hline 64 & prototrófico & ino met & leu ino met & leu ino met \\
\hline 65 & prototrófico & leu ino met & leu ino met & leu ino met \\
\hline 66 & leu lys met & $\begin{array}{c}\text { leu lys met arg } \\
\text { (9) }\end{array}$ & $\begin{array}{c}\text { leu lys met arg } \\
\text { (9) }\end{array}$ & $\begin{array}{c}\text { leu lys met arg } \\
\text { (9) }\end{array}$ \\
\hline 67 & prototrófico & ino met & leu ino met & leu ino met \\
\hline 68 & prototrófico & ino met & leu ino met & leu ino met \\
\hline
\end{tabular}

Quadro 1 - Análise da estabilidade dos marcadores de auxotrofia das colônias recombinantes em quatro gerações de crescimento.

(9) - morfologia e marcadores de auxotrofia do parental 9;

(12) - marcadores de auxotrofia do parental 12;

* - colônia a qual cresceu em todos os meios seletivos, mas não cresceu no meio mínimo (MM). 
Dos 111 recombinantes identificados originalmente, 68 foram analisados, desde que o restante (43) apresentou prototrofia para todos os marcadores envolvidos.

Após a $3^{\mathrm{a}}$ geração de crescimento dos 68 recombinantes, 58 (5,51\% do total de colônias analisadas) continuaram sendo recombinantes (prototróficos ou não), os 10 restantes reverteram para o parental 9 (leu lys met $\arg$ w) (Quadro 1).

Dos 58 recombinantes, 7 foram prototróficos e os 51 restantes continham as marcas leu ino met (Quadro 1).

Alguns autores têm descrito análises de recombinantes instáveis de Trichoderma (Bagagli et al., 1995; Pe`er \& Chet, 1990; Sivan et al., 1990; Stasz et al., 1988; Stasz et al., 1989; Stasz \& Harman, 1990). Em todos os casos estudados, quando os recombinantes originalmente isolados foram submetidos a subcultivos, seja por obtenção de culturas monospóricas ou por isolamento dos setores obtidos, e os marcadores em estudo analisados, muitos destes recombinantes reverteram para um dos parentais envolvidos nos cruzamentos. Entretanto, muitos recombinantes continuaram originando novos variantes e formando novos setores, e alguns chegam a um nível de estabilização após algumas gerações de subcultivo em meios de cultura não seletivos. No entanto, nas vezes em que estes recombinantes foram analisados com o uso de marcadores moleculares, no caso isoenzimas, todos apresentaram os padrões isoenzimáticos de somente um dos parentais envolvidos nos diferentes cruzamentos estudados.

Verificou-se também que todos os recombinantes instáveis obtidos, os quais apresentavam bordas irregulares de crescimento, esporulação esparsa e a formação de setores, possuíam a marca inositol (ino) em comum. A linhagem parental 12L também contém a marca de auxotrofia para o inositol e quando esta foi inoculada em meio completo sem a suplementação de inositol a mesma apresentou colônias com bordas irregulares de crescimento, esporulação esparsa e a formação de setores. Os recombinantes, os quais não apresentaram a marca inositol (ino), possuíam intensa esporulação e com exceção de um recombinante prototrófico, possuíam bordas regulares de crescimento sem a formação de setores, com fenótipo semelhante à linhagem selvagem (Figura 7). Uma sugestão é que a marca inositol ou alguma região próxima 
(ligada) no genoma, talvez até mesmo uma seqüência de transposição, possa estar de alguma forma relacionada com a instabilidade apresentada por estas linhagens.

(a)

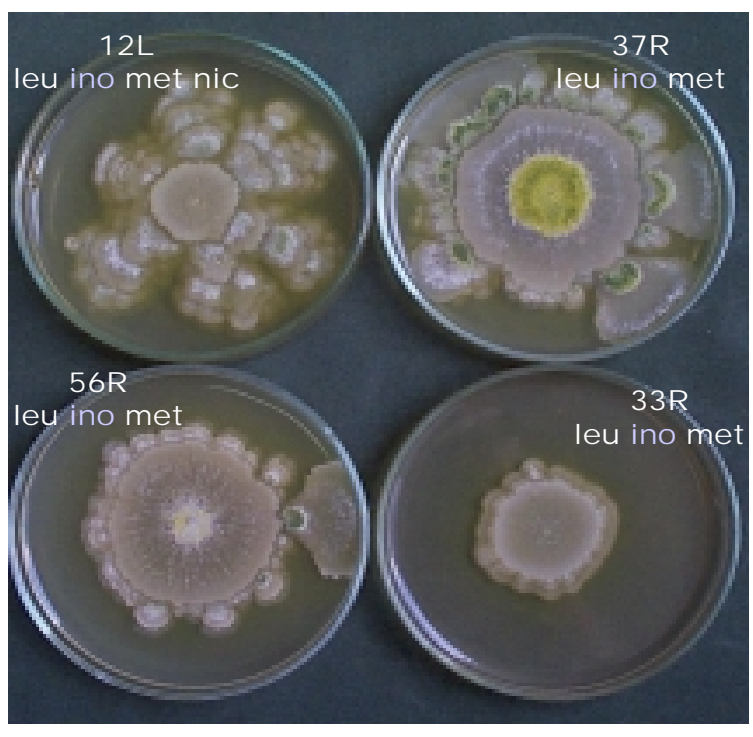

(b)

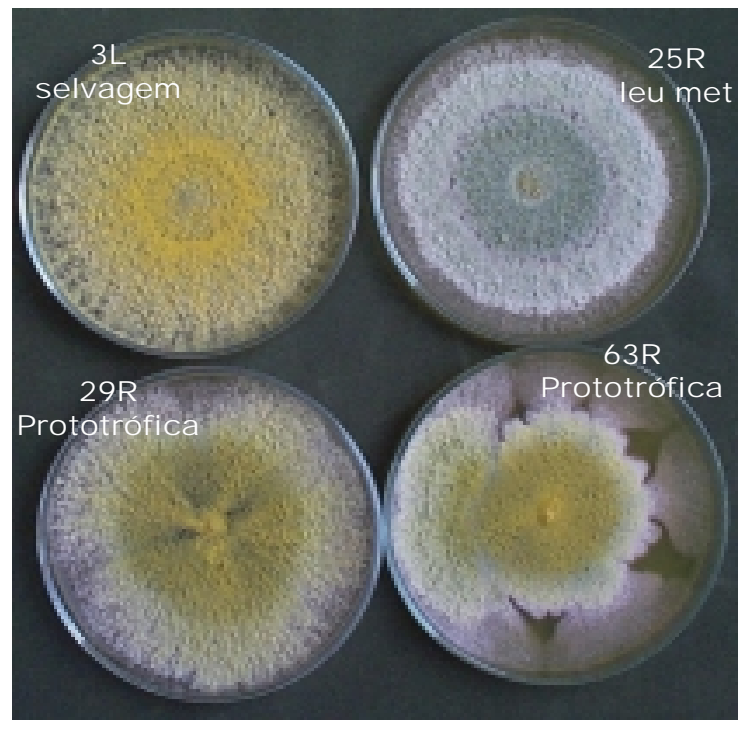

Figura 7 - Aspecto de crescimento das colônias em meio completo (MC) sem a suplementação do inositol. (a) Linhagens apresentando a marca de auxotrofia para o inositol (ino) - colônias com bordas irregulares de crescimento e esporulação esparsa, com a formação de setores; (b) Linhagens que não apresentam a marca de auxotrofia para o inositol colônias que, quando comparadas com a linhagem selvagem, apresentam esporulação intensa e bordas normais de crescimento, com exceção do recombinante prototrófico $63 \mathrm{R}$, que produz setores.

\subsection{Análise dos recombinantes por marcadores RAPD}

A partir da seleção de primers (item 4.1, e Figuras 1 e 3) os quais proporcionaram perfis de bandas contrastantes entre os parentais 9L e 12L envolvidos nos cruzamentos, realizou-se a amplificação dos DNAs dos recombinantes com a 
utilização de 17 primers inicialmente selecionados. Os resultados são apresentados nas Figuras 8, 9, 10 e 11.

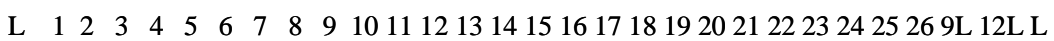

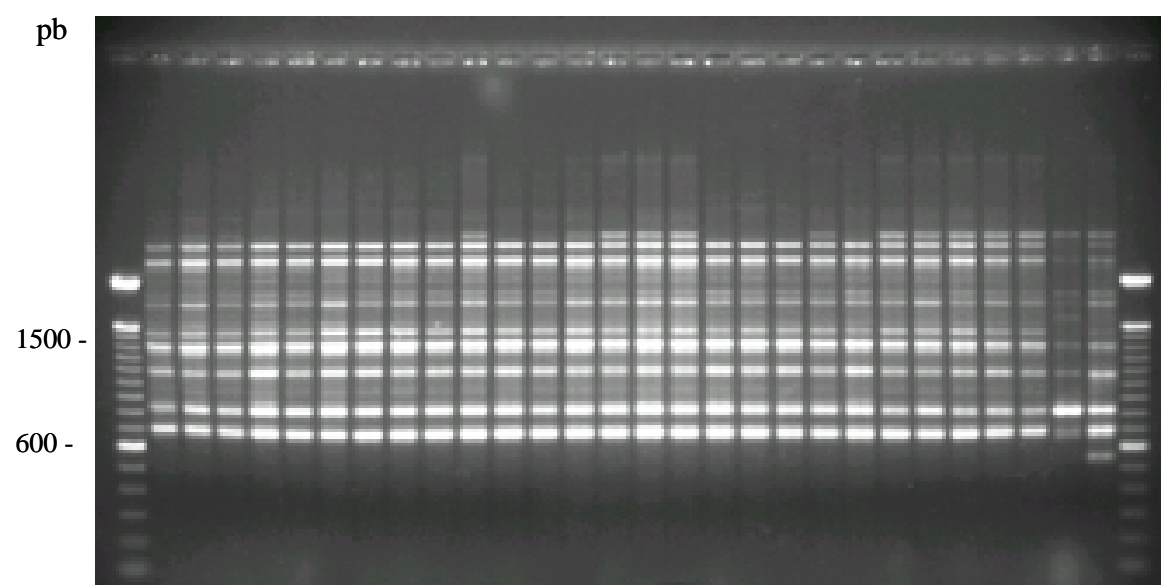

(a)

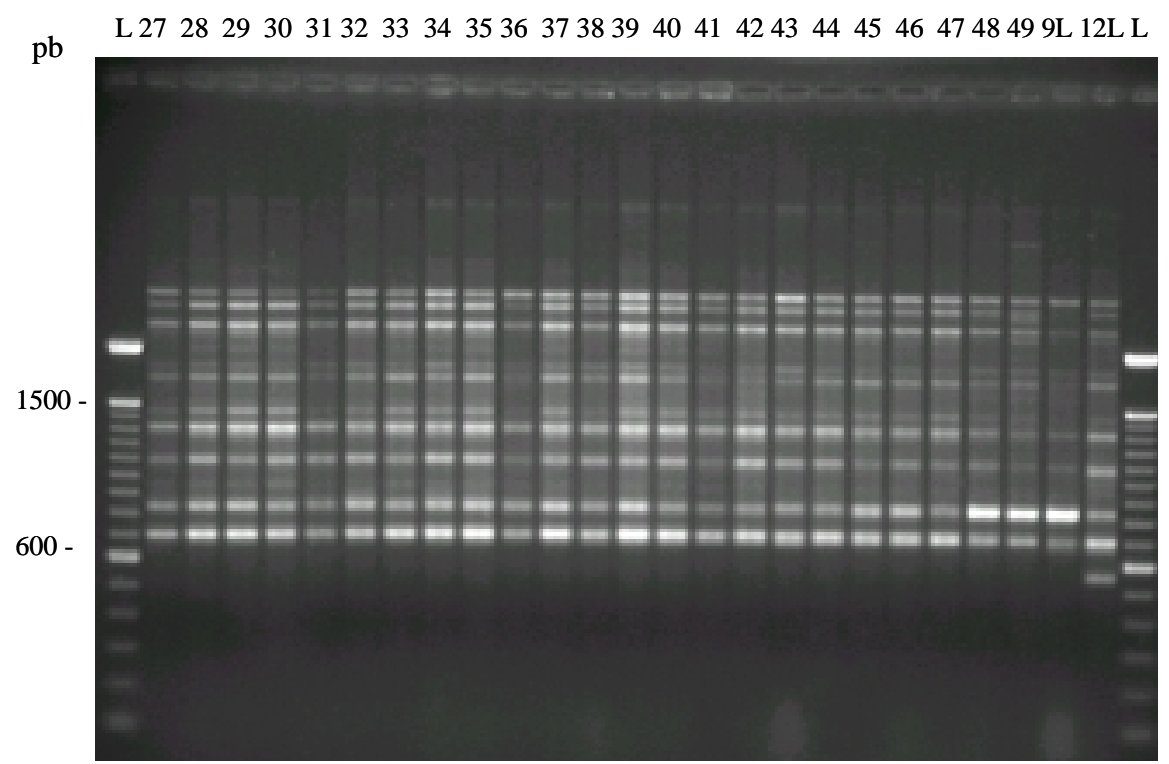

(b)

Figura 8 - RAPD de 49 recombinantes e dos parentais 9L e 12L com o primer AX17 (Operon). 1 - 49: recombinantes; 9L e 12L: linhagens parentais utilizadas nos cruzamentos; L : marcador de peso molecular Ladder (Invitrogen); pb peso molecular das bandas em pares de bases. 


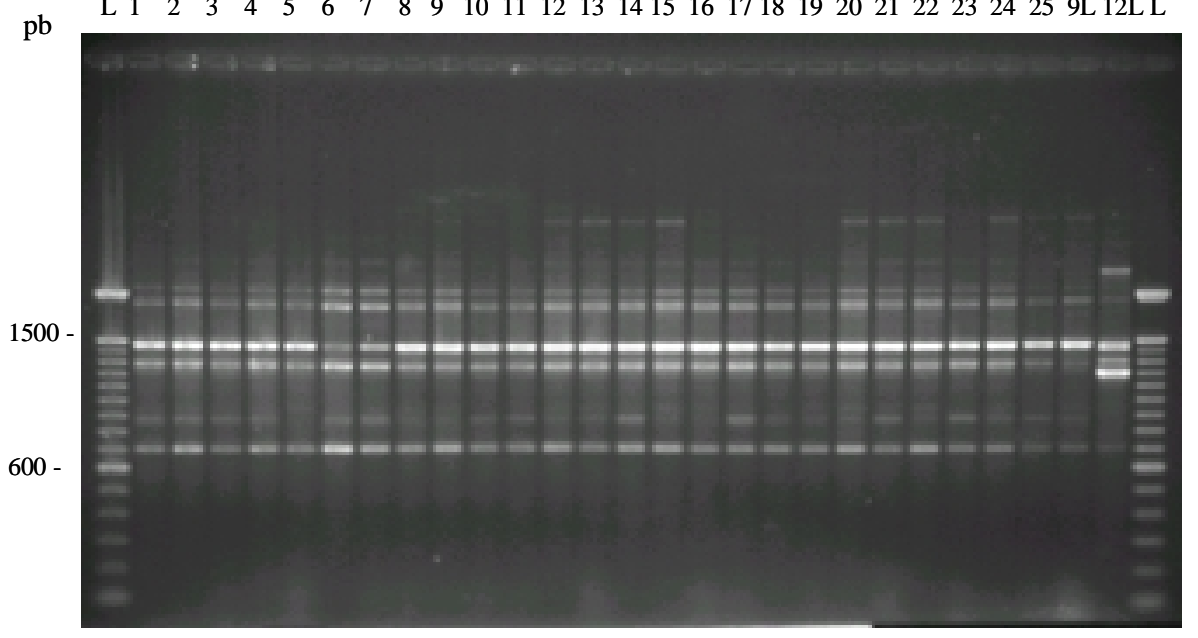

$\begin{array}{llllllllllllllllllllllllllll}\mathrm{L} & 1 & 2 & 3 & 4 & 5 & 6 & 7 & 8 & 9 & 10 & 11 & 12 & 13 & 14 & 15 & 16 & 17 & 18 & 19 & 20 & 21 & 22 & 23 & 24 & 25 & 9 \mathrm{~L} & 12 \mathrm{~L} \\ \mathrm{~L}\end{array}$

(a)

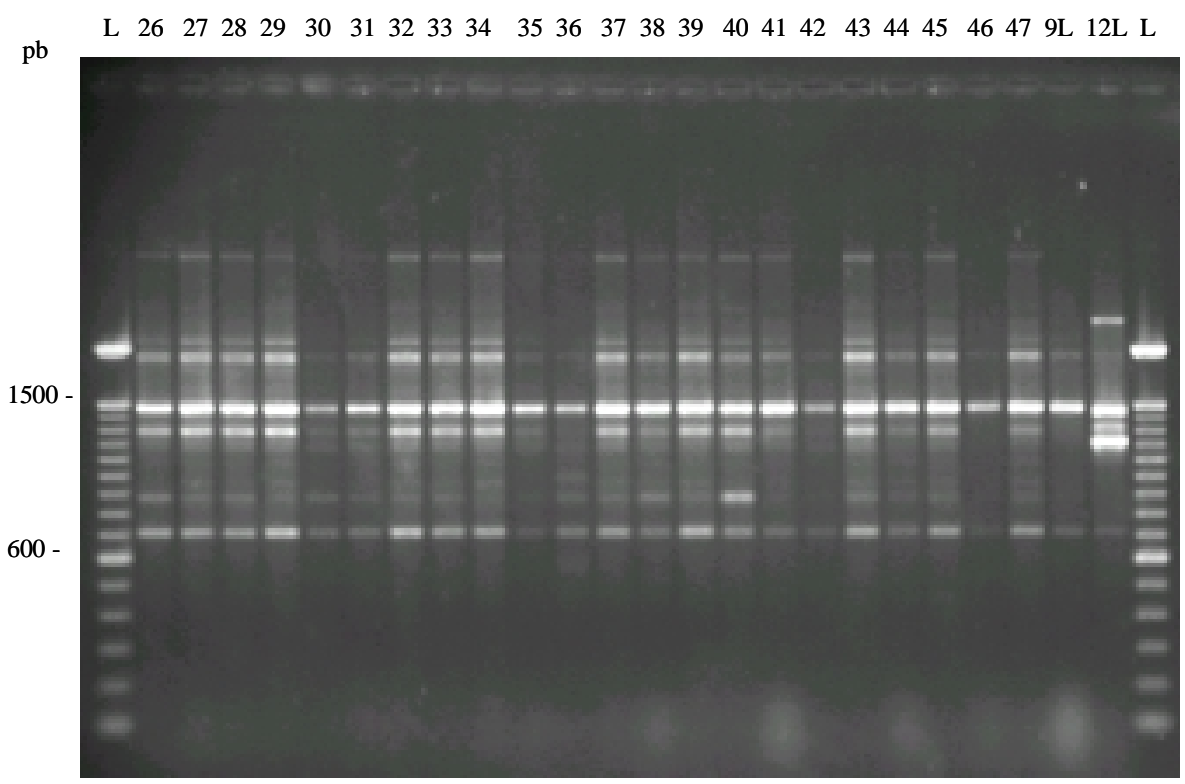

(b)

Figura 9 - RAPD de 47 recombinantes e das linhagens parentais 9L e 12L com o primer AX03 (Operon). 1 - 47: recombinantes; 9L e 12L: linhagens parentais utilizadas nos cruzamentos; L: marcador de peso molecular Ladder (Invitrogen); pb: peso molecular das bandas em pares de bases. 


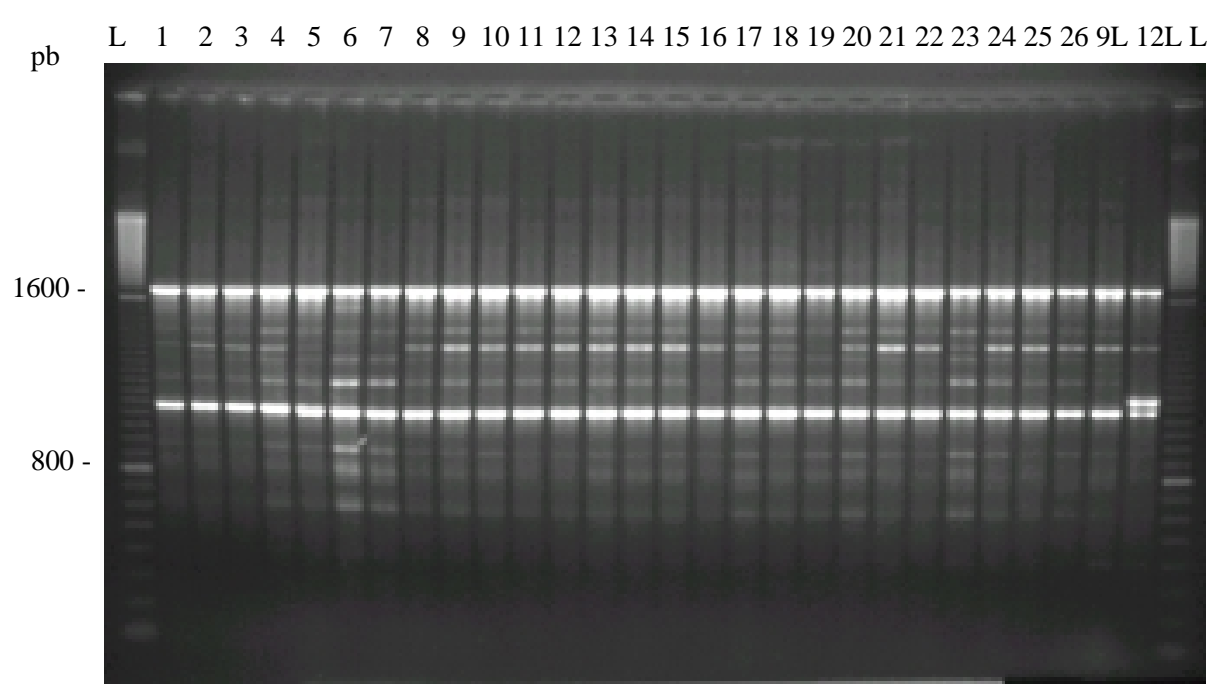

(a)

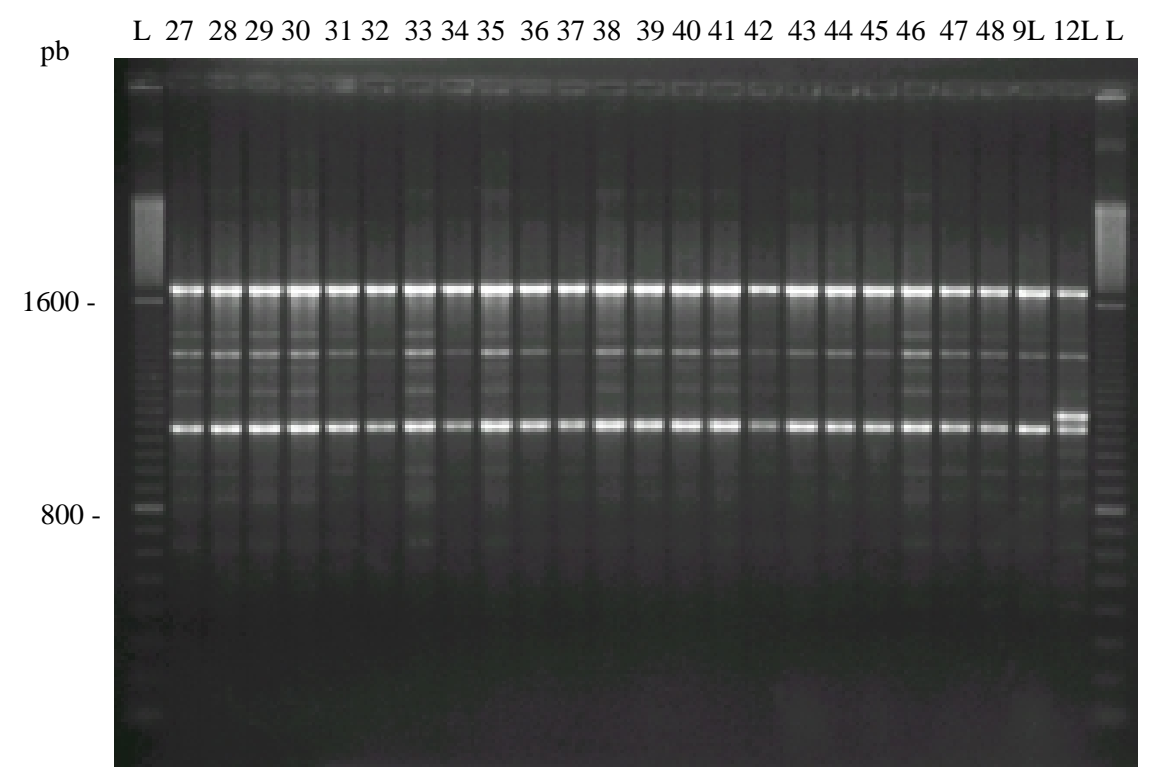

(b)

Figura 10 - RAPD de 48 recombinantes e das linhagens parentais 9L e 12L com o primer X17 (Operon). 1 - 48: recombinantes; 91 e 12L; linhagens parentais utilizadas nos cruzamentos; L: marcador de peso molecular Ladder (Invitrogen); pb: peso molecular das bandas em pares de bases. 


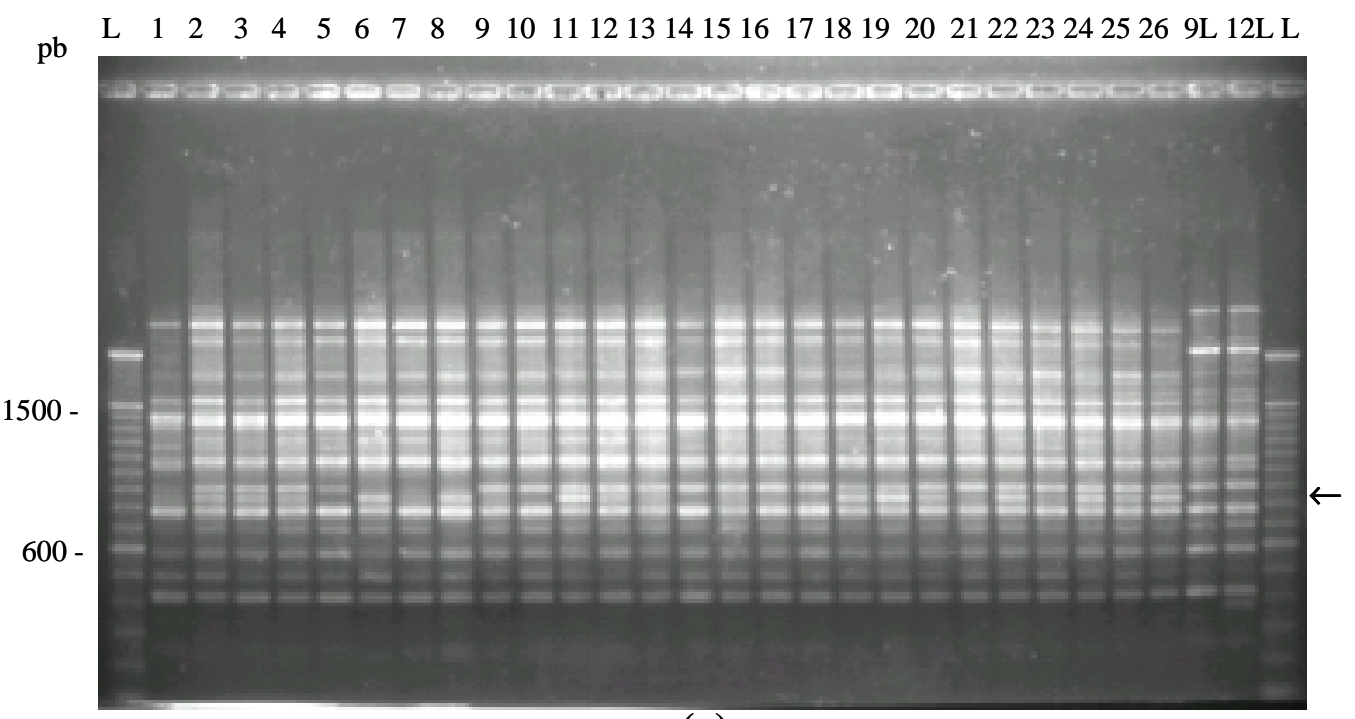

60

(a)

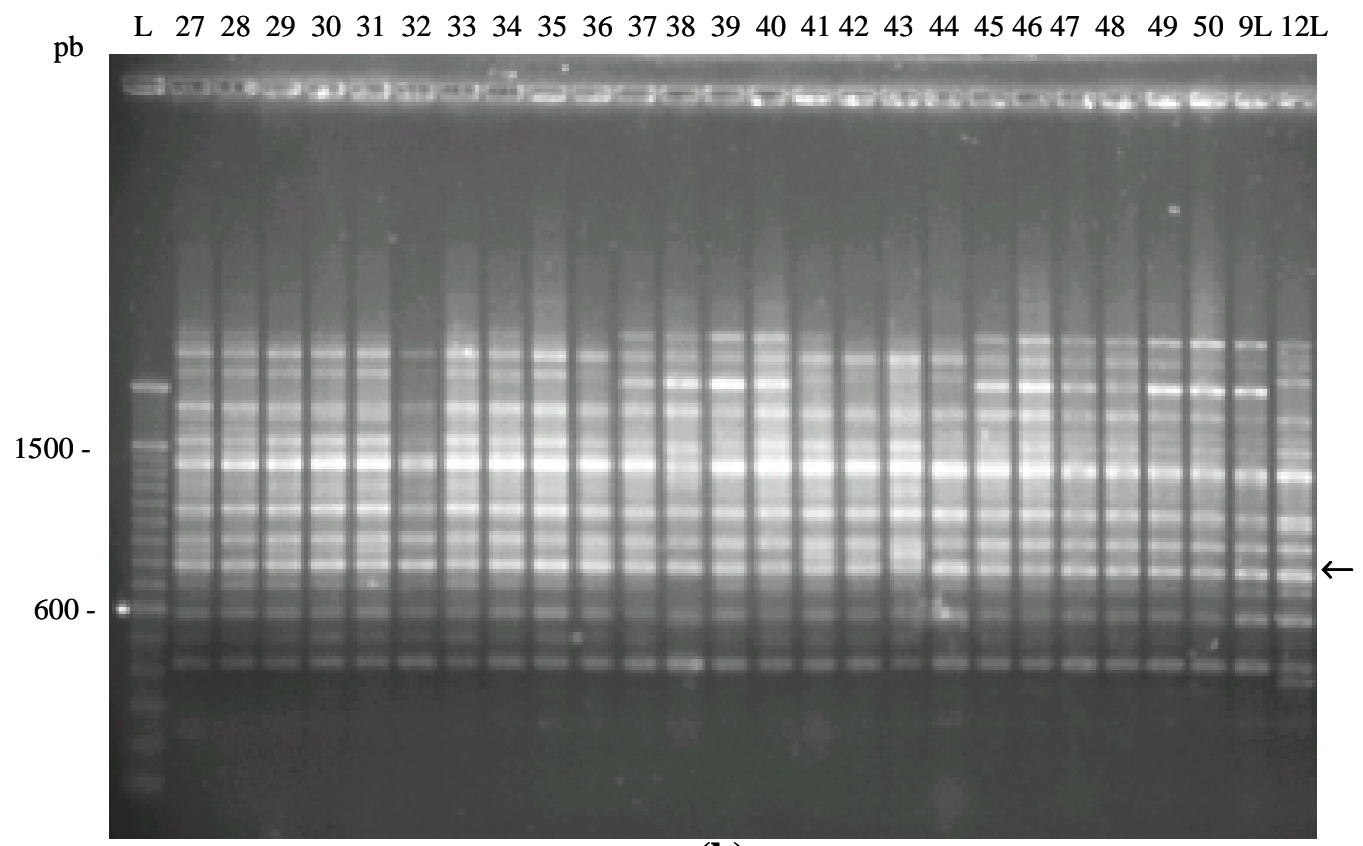

(b)

Figura 11 - RAPD de 50 recombinantes e das linhagens parentais 9L e 12L com o primer P19 (Operon). 1 - 50: recombinantes; 9L e 12L: linhagens parentais utilizadas nos cruzamentos; L: marcador de peso molecular Ladder (Invitrogen); pb: as bandas estão em pares de bases; seta: banda polimórfica (em torno de $850 \mathrm{pb}$ ) entre os recombinantes e ausente nas linhagens parentais. 
São apresentados nas Figuras de 8 a 11, 4 dos 17 primers utilizados nas amplificações, analisando-se em torno de 50 dos 111 recombinantes obtidos originalmente.

Observou-se que em todas as amplificações realizadas, todos os recombinantes apresentaram perfis de bandas muito semelhantes, embora tenha surgido em alguns primers uma ou outra banda polimórfica (Figura 11). Além disso, todos os recombinantes com todos os primers analisados, apresentaram perfis de bandas semelhantes à somente um dos parentais envolvidos nos cruzamentos, no caso o parental 9L, com a ausência da banda adicional presente na linhagem 12L na maioria das amplificações.

Estes resultados contrastam com a aparência morfológica das colônias recombinantes, uma vez que estas foram muito semelhantes à linhagem parental 12L (Figuras 2, 6 e 7). Verificou-se que a linhagem parental 12L utilizada originalmente nos cruzamentos, mantida em estoque no laboratório, devida a sua instabilidade em meio não seletivo, principalmente sem a suplementação do inositol (Figura 7), perdia após sucessivas repicagens a presença das bandas adicionais apresentadas em quase todas as amplificações com os diferentes primers utilizados.

No entanto, na amplificação utilizando o primer P19 (Figura 11), constatou-se uma banda polimórfica de \pm 850 pb entre os recombinantes analisados, a qual não está presente nas linhagens parentais (setas). Além disso, as linhagens parentais apresentaram duas bandas de alto peso molecular as quais não estão presentes em muitos dos recombinantes.

Silva \& Pizzirani-Kleiner (1999) descreveram uma análise por RAPD de recombinantes de $T$. pseudokoningii obtidos via fusão de protoplastos. Foram analisados 10 recombinantes com 10 primers diferentes. Em todos as amplificações realizadas, todos os recombinantes foram idênticos à somente um dos parentais, ao qual eles se assemelhavam morfologicamente e pelas marcas de auxotrofia. 
Stasz \& Harman (1990) analisaram por marcadores isoenzimáticos progênies recombinantes obtidas a partir de vários cruzamentos via fusão de protoplastos entre e dentre várias espécies de Trichoderma. Foram analisadas mais de 1.000 linhagens recombinantes obtidas dos vários cruzamentos, e em todos os casos, os padrões izoenzimáticos apresentados pelos recombinantes foi idêntico à somente um dos parentais utilizados nos cruzamentos. Não foram encontrados padrões izoenzimáticos recombinantes em nenhuma das linhagens recombinantes (para os marcadores de auxotrofia envolvidos nos cruzamentos) analisadas. Com base nestes resultados os autores sugerem que os dados obtidos não mostram evidência da ocorrência de processos parassexuais. Os autores sugerem que na fusão de protoplastos, os núcleos de uma das linhagens parentais (parental não prevalente) são degradados e pequenas porções do genoma seriam incorporadas nos núcleos intactos da outra linhagem parental (parental prevalente). Assim seriam gerados recombinantes com características de transformantes, ou seja, contendo somente poucas seqüências genômicas do parental não prevalente inseridas no genoma dos núcleos do parental prevalente.

Dalzoto (1999) analisando recombinantes de Beauveria bassiana via RAPD, observou que a maioria dos recombinantes (para marcadores de auxotrofia) estudados apresentaram padrões de bandas idênticos à somente um dos parentais envolvidos nos cruzamentos.

Durand et al. (1993) analisaram, via marcadores RAPD, recombinantes (para marcadores de resistência à antibióticos) de Penicillium roquefortii obtidos via fusão de protoplastos. Os autores verificaram que a maioria dos recombinantes apresentou perfis de banda, com o uso de diferentes primers, de somente um dos parentais. Também foram observadas bandas adicionais nos recombinantes, não existentes nos parentais envolvidos nos cruzamentos. Além disso, observaram também com o uso de um primer a presença de bandas nos dois parentais não existentes em muitos recombinantes.

Considerando-se os resultados obtidos com as análises dos recombinantes, ou seja: - a instabilidade da maioria dos recombinantes obtidos, demonstrada pela esporulação descontínua, pela presença de bordas irregulares de crescimento e a freqüente formação de setores (Figura 6 e 7); - a alteração observada nas marcas de 
auxotrofia nas quatro gerações de crescimento, com a reversão das marcas para um dos parentais em alguns recombinantes e a conversão para as marcas leu ino met (auxotrofia para leucina, inositol e metionina, respectivamente) na maioria dos recombinantes estudados (Quadro 1) e; - perfis de bandas de RAPD apresentado pelos recombinantes, semelhantes à somente um dos parentais (Figuras 8 a 11), são indícios da ocorrência de outros eventos distintos dos processos parassexuais convencionais de recombinação, incluindo a parameiose. Eventos estes que não envolveriam a fusão de núcleos e a formação de diplóides, como sugerido por Stasz \& Harman (1990) para as espécies de T. hamatum, T. koningii, T. viride e T. harzianum. No entanto, no nosso caso, não se pode descartar ainda a ocorrência dos mecanismos parassexuais de recombinação, no caso a parameiose, sendo necessário a realização de mais estudos,

principalmente de estudos citológicos da formação dos heterocários e das regiões de anastomose de hifas.

\subsection{Reamplificações de bandas isoladas de RAPD}

Com o objetivo inicial de se confeccionar sondas de DNA específicas, para futuras hibridizações dos DNAs dos recombinantes, a partir de bandas de RAPD amplificadas do DNA dos mesmos, foram isoladas bandas de RAPD dos géis de agarose de algumas reações de RAPD descritas no item 4.3, e as mesmas reamplificadas (item 3.11 e Figura 12).

Como pode ser observado na Figura 12, a maioria das bandas reamplificadas, originaram uma ou mais bandas adicionais de peso molecular menor. Este fato sugere que estas regiões do genoma amplificadas possam representar seqüências contendo repetições. Assim sendo, muitas das diferentes bandas resultantes das amplificações de RAPD podem representar amplificações dentro de um mesmo segmento do genoma. No entanto foram obtidas bandas que quando reamplificadas originaram somente a mesma banda de mesmo peso molecular. 


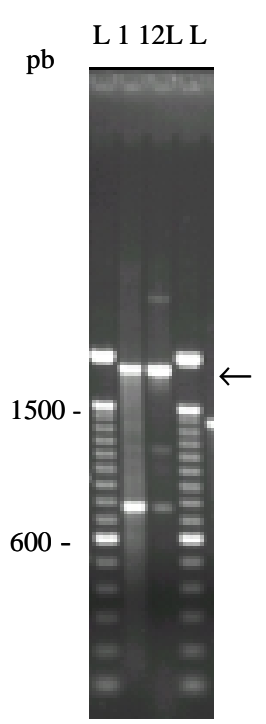

(a)

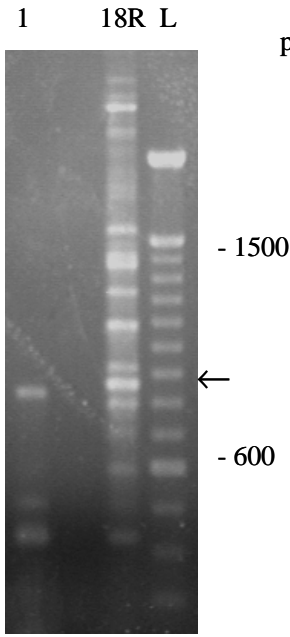

(e)

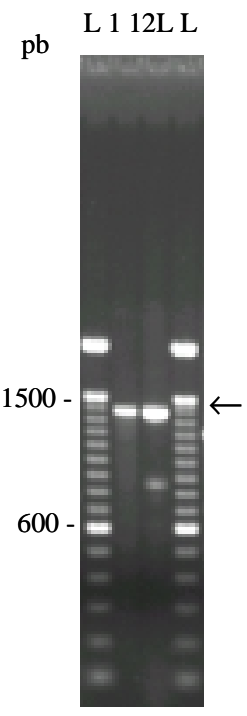

(b)

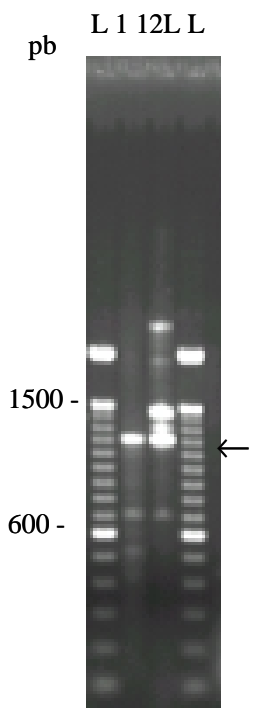

(c)

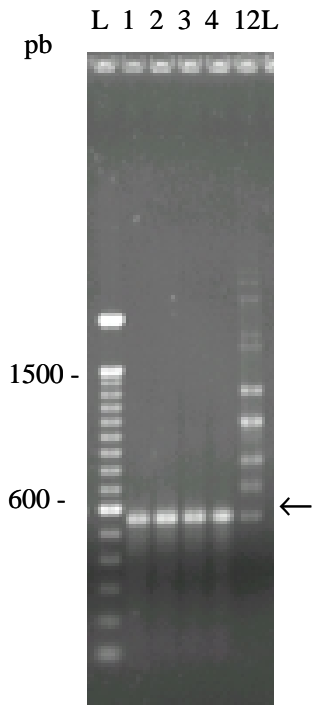

(d)

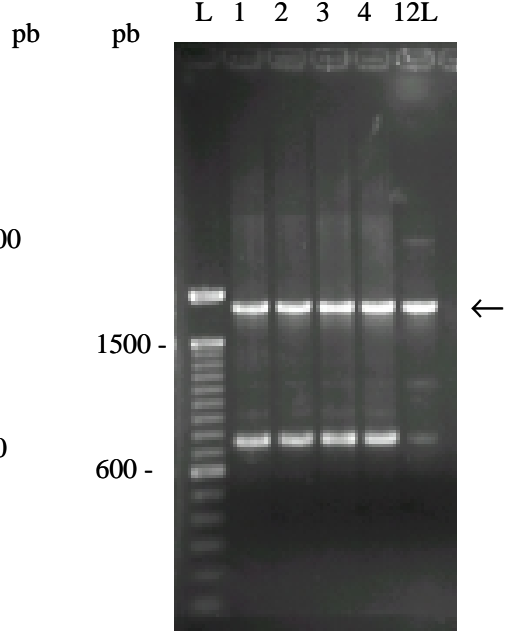

(f)

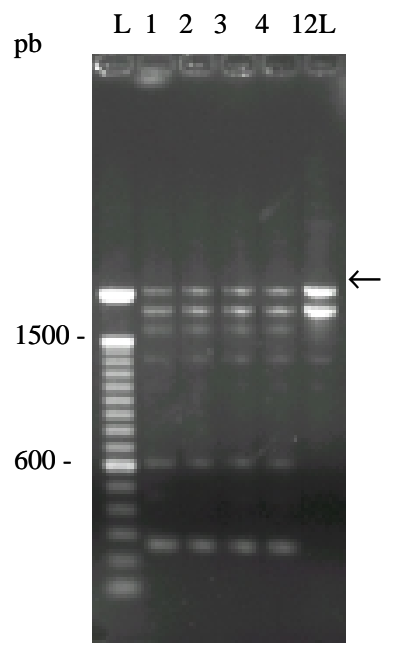

(g)

Figura 12 - Reamplificação de bandas de DNA (setas) isoladas dos géis de agarose das amplificações de RAPD (item 4.4). Com exceção da figura (e), todas as reações de reamplificação foram feitas a partir de bandas isoladas de reações de amplificação do DNA da linhagem parental 12L, no caso da figura (e) foi utilizada uma reação de amplificação do DNA da linhagem recombinante 18R. (a) reamplificação com o uso do primer A16 de uma banda de $\pm 1.850 \mathrm{pb}$ (seta), 1 - reação de reamplificação; (b) reamplificação com o uso do primer P7 de uma banda de $\pm 1.400 \mathrm{pb}, 1$ - reação de reamplificação; (c) reamplificação com o uso do primer AX03 de uma banda de $\pm 1.200 \mathrm{pb}, 1$ - reação de reamplificação; (d) reamplificação com o uso do primer AX17 de uma banda de $\pm 550 \mathrm{pb}, 1$ - reação de reamplificação; (e) reamplificação com o uso do primer P19 de uma banda de $\pm 850 \mathrm{pb}, 1$ - reação de reamplificação; (f) reamplificação com o uso do primer A16 de uma banda de $\pm 1.850 \mathrm{pb}, 1$, 2, 3 e 4 - reações de reamplificação; (g) reamplificação com o uso do primer G13 de uma banda de $\pm 2.100 \mathrm{pb}, 1,2,3$ e 4 - reações de reamplificação. $\mathrm{L}$ - marcador de peso molecular Ladder (Invitrogen), $\mathrm{pb}$ - peso molecular das bandas em pares de bases. 
Arnau et al. (1994) ao utilizarem marcadores RAPD para análises genéticas de recombinantes de Cladosporium fulvum, realizaram reamplificações de bandas isoladas dos géis das reações de RAPD com o objetivo de se confeccionar sondas para futuras hibridizações nos DNAs genômicos destes recombinantes. $\mathrm{Na}$ maioria das reamplificações, ocorreu o aparecimento de bandas adicionais de peso molecular menor. Assim estes autores sugeriram que estas bandas representariam regiões de DNA repetitivo.

É importante ressaltar aqui que a maioria destas bandas isoladas dos géis de RAPD e reamplificadas eram aquelas bandas adicionais presentes na linhagem parental 12L e ausente na linhagem parental 9L e nos recombinantes, além disso com sucessivas repicagens da linhagem 12L em meio não seletivo, principalmente sem a suplementação do inositol (marca deficiente nesta linhagem), estas bandas não eram mais observadas (dados não apresentados). Isto pode representar que estas seqüências amplificadas podem estar localizadas em regiões instáveis do genoma desta linhagem, regiões estas as quais podem conter duplicações, repetições invertidas ou até mesmo sequiências de transposição. Estes fatos somente poderão ser investigados com futuras hibridizações destas bandas com o DNA genômico da linhagem 12L clivado com enzima de restrição e com os cromossomos separados por eletroforese em campo pulsado, além do seqüênciamento destas bandas.

Aqui são apresentados os resultados do sequiênciamento de uma destas regiões reamplificadas, a confecção de primers específicos e a amplificação desta região a partir do DNA dos parentais e recombinantes (Figura 13). 
primer A7 (operon)

$\downarrow$

\begin{abstract}
5`ATTGAAACGGGTGGTGAACCCAGCTCAGGAACCTCTCCAGGTTAT TCAATCCATTAGAAAAATGGCAACCAAACGTGACCACAAGCAGGTT GATCTTGATCGTCACAAGCGAACTTTCAAGAAGTACGAGGACAAGA AGGAGCGAACTGCCAAAGATGAGGAAAAGATGTATAATGCTGAGGC

(a) AGAAGTTCATGTAGCACAGGAGGAGTACGACTACTATAATGAGATG TTGAAGAATGAATTGCCGGTTTTGTTCCAGATGCAATCAGACTTCAT TCGTCCACTTTTCGTCAGTTTCTACTACATGCAATTGAACATCTTCTA TACGTTGTACCAACGCATGGAGGAACTCAAGATTCCATACTTTGACT TGAACTCCGACATTGTTGAGGCTTATCAC3
\end{abstract}

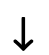

primer F-5`AAC GGG TGG TGA ACC CAG C3`

(b)

primer R - 5 ' GAC GAA AAG TGG ACG3

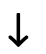

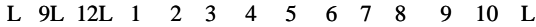

(c)

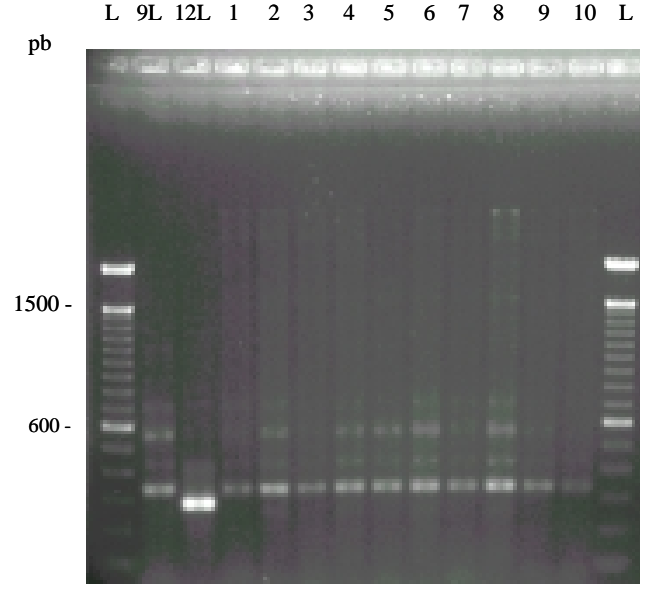

Figura 13 - Construção de um par de primers com base na sequiência de nucleotídeos de uma banda (seqüência) amplificada por RAPD com o primer A7 e a utilização destes em reações de PCR. (a) Seqüência de nucleotídeos de uma banda cortada do gel (DNA do parental 12L) de RAPD, amplificada com o uso do primerA7 e reamplificada com o mesmo primer. (b) Foram construídos um par de primers (primer F e R), com base na seqüência de nucleotídeos obtida, específicos para serem utilizados nas reações de amplificação (PCR) dos DNAs dos parentais e dos recombinantes. (c) Reação de amplificação (PCR) com o uso dos primers confeccionados. 9L e 12L - linhagens parentais; 1-10 linhagens recombinantes; L - marcador de peso molecular Ladder. pb - pesos moleculares em pares de bases. 
Novamente aqui, todos os recombinantes analisados foram iguais a somente o parental 9L (Figura 13) como ocorrido para a maioria das reações de RAPD realizadas (Figuras de 8 a 11). A comparação desta sequiência com as existentes em bancos de seqüências (BLAST / NCBI), revelou uma maior similaridade com um gene de Saccharomyces cerevisiae que codifica para uma proteína envolvida em processos de endocitose, e está relacionada também a mecanismos de resistência a falta de nutrientes (proteína Rvs167p). Não foi localizada a existência de sequiências de transposição.

\subsection{Separação dos cromossomos por eletroforese em campo pulsado (PFGE)}

As preparações dos cromossomos para a eletroforese em campo pulsado foram feitas conforme descrito nos itens 3.6 e 3.7. A separação dos cromossomos por eletroforese em campo pulsado foi feita conforme descrito no item 3.8. Na Figura 14 são apresentadas as separações dos cromossomos dos dois parentais utilizados nos cruzamentos (parental 9L e 12L) e de 5 recombinantes além da linhagem selvagem, utilizada como padrão de peso molecular. 


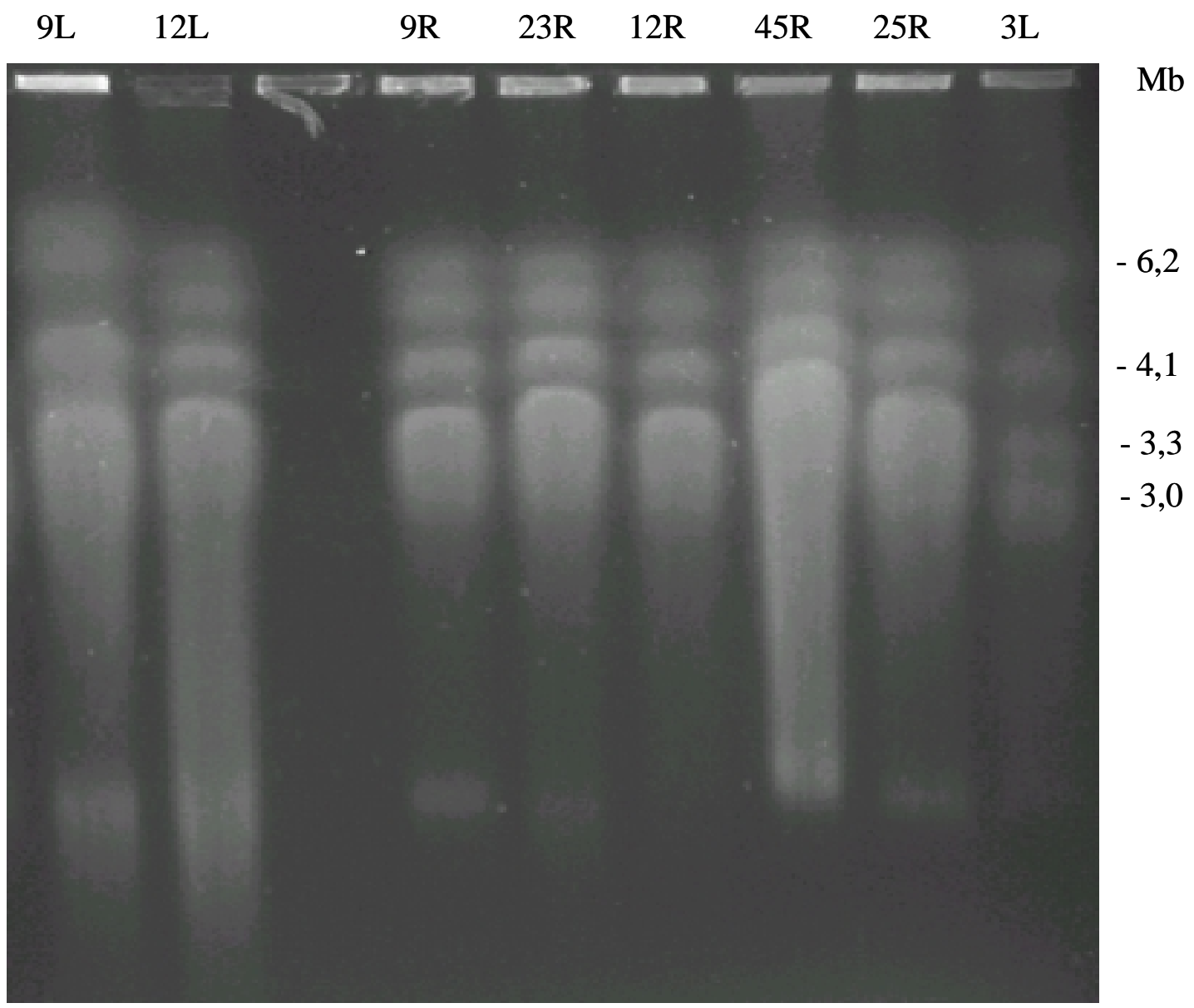

Figura 14 - Separação dos cromossomos por eletroforese em campo pulsado das linhagens parentais 9L e $12 \mathrm{~L}$ e de cinco recombinantes. 9L e $12 \mathrm{~L} \mathrm{-}$ linhagens parentais utilizadas nos cruzamentos; 9R, 23R, 12R, 45R e 25R - linhagens recombinantes; 3L - linhagem selvagem de $T$. pseudokoningii utilizada como padrão de peso molecular (Nadalini, 1997); Mb - peso molecular em megabases. 


\begin{tabular}{|c|c|c|c|c|c|c|}
\hline $9 \mathrm{~L}$ & $12 \mathrm{~L}$ & $9 \mathrm{R}$ & $23 \mathrm{R}$ & $12 \mathrm{R}$ & $45 \mathrm{R}$ & $25 \mathrm{R}$ \\
\hline 7,1 & & & & & & \\
6,5 & & & & & 6,5 & \\
4,7 & 6,3 & 6,3 & 6,3 & 6,2 & & 6,3 \\
& 5,6 & 5,4 & 5,5 & 5,5 & & 5,6 \\
3,6 & 3,6 & 3,6 & 3,7 & 3,5 & & 3,6 \\
\hline
\end{tabular}

Quadro 2 - Representação esquemática das bandas cromossomais apresentadas na Figura 14.

Obs. Cada valor representa o peso molecular em megabases de cada banda cromossomal visualizada no gel. Os pesos moleculares das bandas foram determinadas com o uso do programa de computador "Sigmagel" tendo como padrão de peso molecular as bandas cromossomais da linhagem selvagem de T. pseudokoningii (Nadalini, 1997). Como critério de discriminação para a classificação dos cromossomos utilizou-se $5 \%$ do valor entre o maior peso $(7,1 \mathrm{Mb})$ e o menor peso $(3 \mathrm{Mb}$, da linhagem selvagem), sendo este valor de 0,2Mb (“Sigmagel”). 9L e 12L - linhagens parentais; 9R, 23R, 12R, 45R e 25R - linhagens recombinantes.

Das cinco linhagens recombinantes analisadas, quatro foram semelhantes quanto ao padrão de bandas cromossomais à linhagem 12L. As linhagens recombinantes $23 \mathrm{R}$ e 25R apresentaram um padrão de bandas igual ao da linhagem 12L (Figura 14 e Quadro 2). As linhagens $9 \mathrm{R}$ e $12 \mathrm{R}$ são semelhantes à linhagem $12 \mathrm{~L}$, porém possuem um cromossomo menor (de 4,4Mb na linhagem $12 \mathrm{~L}$ para $4,2 \mathrm{Mb}$ ). A linhagem recombinante 
$45 \mathrm{R}$, possui duas bandas cromossomais semelhantes às da linhagem $9 \mathrm{~L}(6,5 \mathrm{Mb} \mathrm{e}$ $4,9 \mathrm{Mb})$, porém possui duas bandas cromossomais diferentes (5,8 $\mathrm{Mb}$ e $4,0 \mathrm{Mb})$.

Estes resultados confirmam os dados das análises de auxotrofia (Quadro 1) e das características morfológicas das linhagens recombinantes (item 4.2), de que a maioria das linhagens recombinantes obtidas, senão todas, são semelhantes somente ao parental 12L. A linhagem 45R, a qual apresentou um padrão distinto de bandas, pelas características morfológicas da colônia e pela marcas de auxotrofia (presença da marca de auxotrofia para o inositol) se assemelha também à linhagem 12L. Em uma outra análise de separação de cromossomos por PFGE de outros cinco recombinantes, quatro foram semelhantes ao parental 12L (dados não mostrados).

\subsection{Estudos citológicos}

Foram feitos estudos citológicos com o uso da técnica de HCL - Giemsa para colorações nucleares (item 3.4) com os seguintes objetivos: (a) Caracterização do número de núcleos nos conídios das linhagens parentais envolvidas nos cruzamentos, nos conídios formados nas colônias heterocarióticas e de algumas linhagens recombinantes; (b) Estudos da conidiogênese destas linhagens e (c) estudos das anastomoses das hifas e do comportamento nuclear durante os processos de formação do heterocário. Estes estudos foram necessários para uma melhor interpretação dos resultados obtidos com as análises genéticas dos cruzamentos descritos anteriormente.

\subsubsection{Número de núcleos nos conídios das linhagens parentais e recombinantes e estudos da conidiogênese}

Os conídios das linhagens parentais e das linhagens recombinantes foram corados conforme o item 3.4. Os resultados são apresentados na Figura 15. 


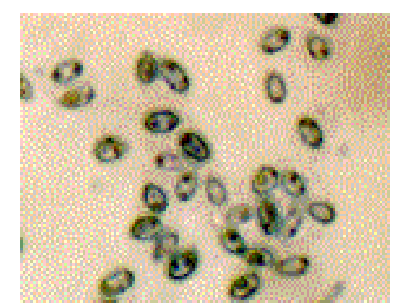

(a)

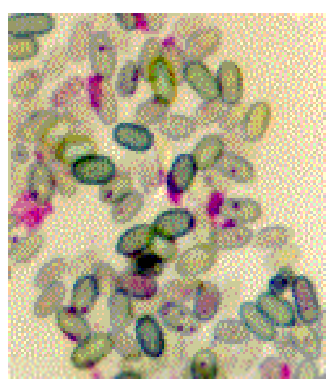

(d)

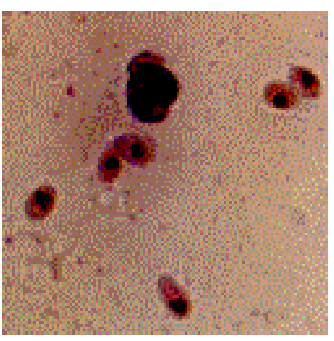

(b)

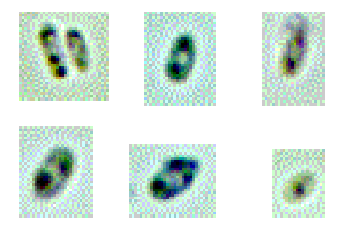

(e)

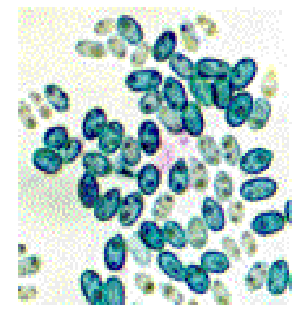

(c)

Figura 15 - Coloração de núcleo dos conídios (item 3.4). (a) linhagem parental 12L; (b) linhagem parental 9L; (c) heterocário; (d) linhagem recombinante 18R; (e) linhagem recombinante 3R; (f) linhagem recombinante 58R. (Aumento de $1.000 x)$

As linhagem 12L (Figura 15, a), o heterocário (Figura 15, c) e a linhagem recombinante 18R (Figura 15, d) apresentaram conídios contendo um, dois, três ou mais núcleos. A linhagem recombinante 18R apresentou alguns conídios contendo até mais de quatro núcleos, sendo que em alguns não foi possível se distinguir núcleos individualizados (Figura 15, d). A linhagem 9L (Figura 15, b) apresentou todos os conídios analisados uninucleados. A linhagem recombinante 3R (Figura 15, e) apresentou conídios uni, bi e trinucleados, e a linhagem recombinante 58R (Figura 15, f) apresentou conídios uni e binucleados.

Stasz et al. (1988) descreveram a ocorrência de conídios multinucleados em linhagens de Trichoderma harzianum. Furlaneto \& Pizzirani - Kleiner (1992) observaram que colônias recombinantes prototróficas de Trichoderma pseudokoningii obtidas a partir de cruzamentos via fusão de protoplastos apresentaram conídios binucleados. Nadalini (1997) estudou o número de núcleos em conídios de duas 
linhagens mutantes auxotróficas, em conídios do heterocário e de um recombinante prototrófico. As duas linhagens mutantes estudas apresentaram conídios uninucleados, no entanto, tanto o heterocário como a linhagem recombinante prototrófica continham conídios uni e binucleados.

Com o objetivo de se estudar a origem dos diferentes núcleos observados nos conídios maduros, estudou-se a distribuição dos núcleos durante a conidiogênese na linhagem parental 12L, no heterocário e em uma linhagem recombinante (Figura 16).

Observou-se em todos os casos a formação de conídios contendo somente um núcleo (Figura 16). Observou-se também que todas as fiálides são uninucleadas (Figura 16 a: 1 e 2; e b: 3, 4 e 5), no caso do recombinante 23R (Figura 16 c: 2) observou-se uma fiálide bicelular mas onde cada compartimento continha somente um núcleo. Foi possível se observar diferentes etapas do processo de conidiogênese, sendo o mesmo melhor estudado no heterocário (Figura 16 b: 1, 2, 3, 4 e 5). Na Figura 16 b: 1 e 2, observa-se a divisão mitótica do núcleo da fiálide, na região de formação do conídio, sendo o núcleo formado introduzido no conídio recém formado (Figura 16 b: 3 e 4). Após a formação do conídio, com a inclusão de um único núcleo, inicia-se o processo de liberação do conídio da fiálide (Figura 16 b: 5). Na linhagem parental 12L e no recombinante $23 \mathrm{R}$, também foi observado a formação de conídios uninucleados (Figura 16 a: 1 e 2 ; e c: 1 e 2). 

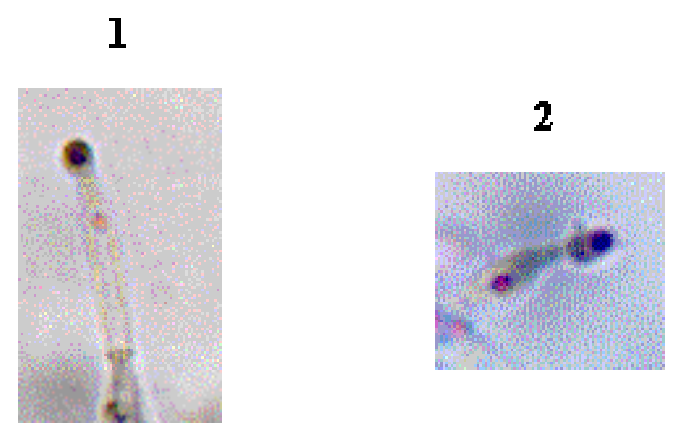

(a)
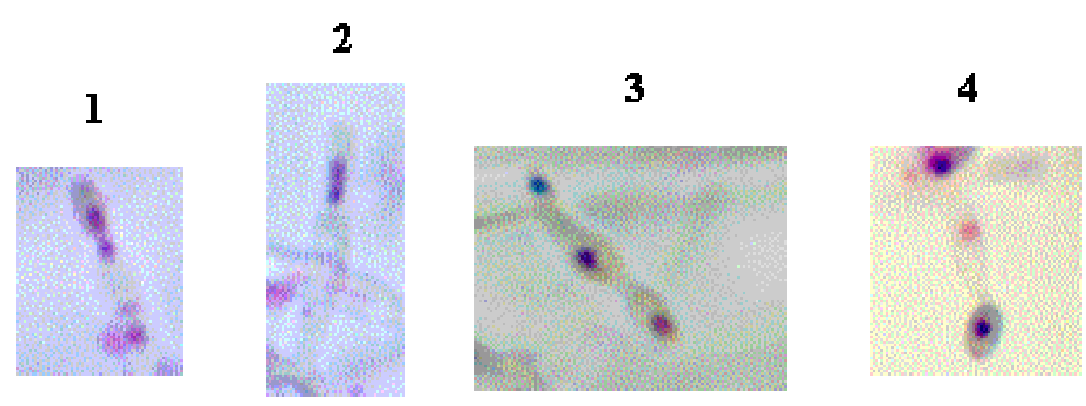

5

(b)

2
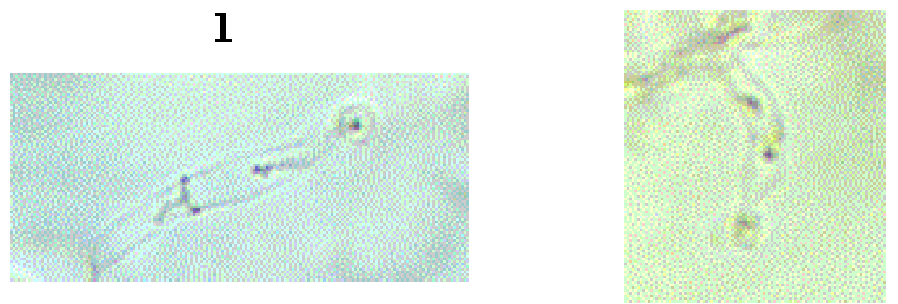

(c)

Figura 16 - Estudo da distribuição nuclear durante o processo de conidiogênese. (a) Conidiogênese na linhagem 12L; (b) Conidiogênese no heterocário; (c) Conidiogênese na linhagem recombinante 23R. (Aumento de 1.000x) 
Hammil (1974) estudou por microscopia eletrônica de transmissão a
conidiogênese no fungo Trichoderma saturnisporum, observando-se fiálides uninucleadas e a ocorrência da formação de conídios uninucleados.

A existência de conídios maduros bi até multinucleados (Figura 15), é provavelmente devida a divisões mitóticas ocorridas após a formação dos mesmos, sendo portanto estes conídios homocarióticos, onde todos os núcleos são originados a partir de um único. Este fato elimina a hipótese dos recombinantes, obtidos originalmente, serem instáveis devido a uma origem a partir de conídios do heterocário contendo núcleos diferentes.

\subsubsection{Estudos das anastomoses das hifas e do comportamento nuclear durante os processos de formação do heterocário}

Para as colorações do heterocário procedeu-se conforme descrito no item 3.4. Os resultados são apresentados na Figura 17. Algumas regiões da colônia heterocariótica analisadas apresentaram hifas multinucleadas, contendo núcleos íntegros (Figura 17 a e e), sendo possível detectar em muitas observações a passagem de núcleos através dos poros nas regiões dos septos (Figura 17 a e b, setas). Em outras regiões observou-se a presença de um material granuloso no citoplasma, não sendo detectado a presença de núcleos íntegros individualizados (Figura 17 b). Em algumas regiões observou-se a presença de hifas intensamente coradas, podendo ser um indício de algum processo de morte celular (Figura 17 c e d, setas). Foi possível observar muitas regiões em diferentes fases da anastomose de hifas (Figura 17 f, g e h, setas). Na Figura 17 f (seta), observa-se uma região com um início de contato entre hifas e anastomose. Na Figura 17 g (seta), observa-se uma região de anastomose apresentando a passagem ativa de um núcleo íntegro. Na Figura 17 h (setas) observas duas regiões de anastomose de hifas com a passagem de núcleos. O movimento ativo dos núcleos no heterocário é evidenciado com as diferentes conformações observadas dos mesmos, desde esféricos (Figura 17 e, seta), na forma elipsóide (Figura 17 h) até em uma forma alongada (Figura 17 g). 

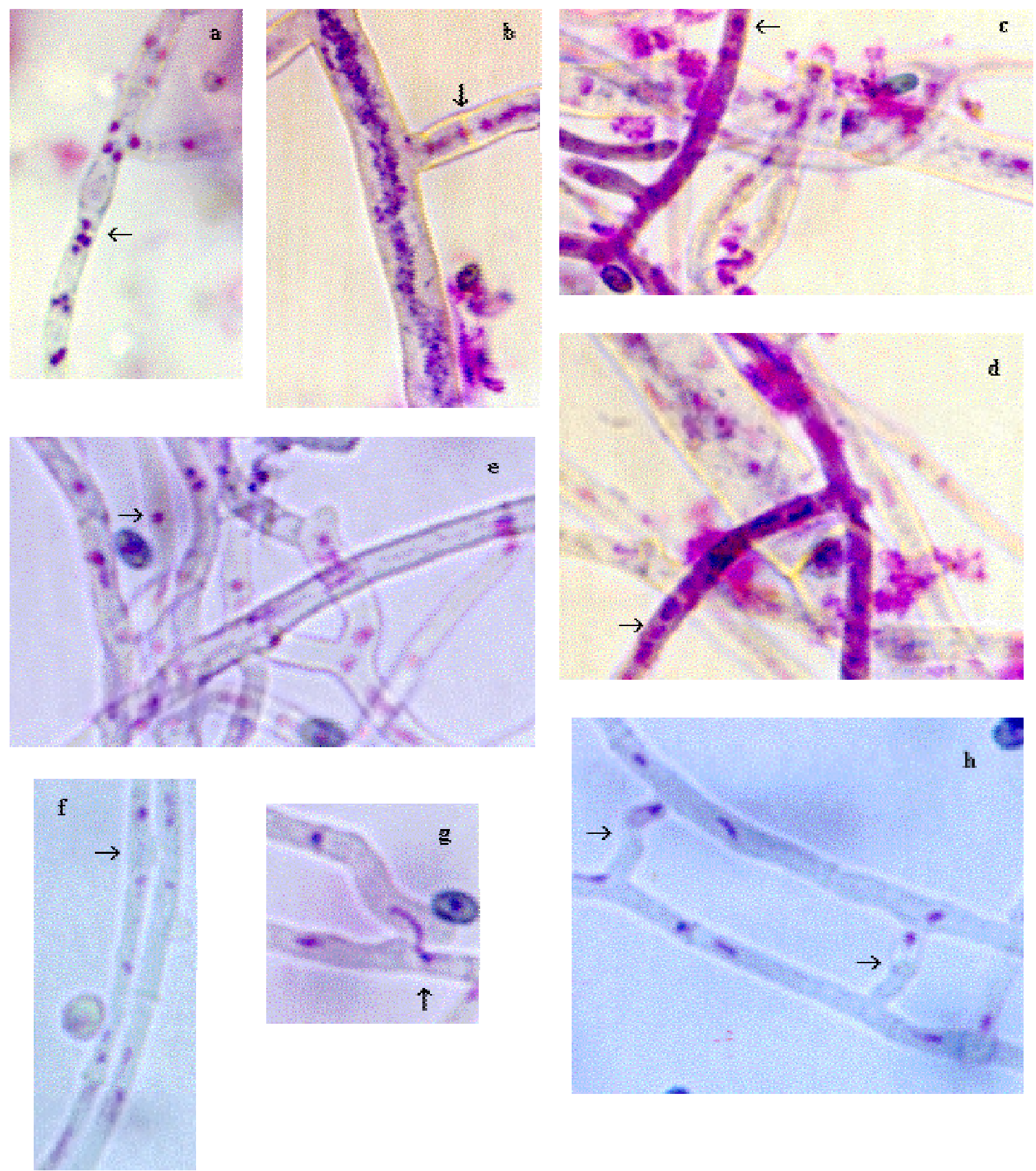

Figura 17 - Observações citológicas da formação do heterocário, das anastomoses de hifas, e do comportamento nuclear durante os processos de formação do heterocário. a - hifa com compartimentos multinucleados, contendo núcleos íntegros, seta - passagem de um núcleo pelo poro na região do septo entre os compartimentos; b - hifa do heterocário apresentando um material fibroso, não sendo observado a presença de núcleos íntegros individualizados, seta - passagem de um núcleo pelo poro na região do septo; c e d - hifa intensamente corada, indício de um processo de morte celular (setas); e - presença de núcleo íntegro individualizado (seta); f - região de contato e início do processo de anastomose (seta); g - região de anastomose de hifa com a passagem ativa de um núcleo individualizado (seta); $\mathrm{h}$ - regiões de anastomose de hifas com a passagem de núcleos (setas). (Aumento de 1.000x) 
Kronland \& Stanghellini (1988) estudaram as anastomoses de hifas e a condição nuclear em heterocários de Rhizoctonia solani. Os autores observaram regiões de anastomoses de hifas mostrando a passagem de núcleos e a integridade dos mesmos na hifa heterocariótica, não apresentando sinais de degeneração.

Embora a heterocariose seja um mecanismo de ocorrência natural em muitas espécies de fungos filamentosos, a qual permite a troca de material genético entre as linhagens envolvidas, existe um mecanismo genético o qual restringe a formação de heterocários entre indivíduos geneticamente diferentes. Se os indivíduos envolvidos na formação do heterocário diferirem em um ou mais locos het (incompatibilidade de heterocário ou incompatibilidade somática), as células envolvidas nas fusões são compartimentalizadas e sofrem um processo lítico que leva à morte celular (Glass et al., 2000). Este fenômeno é denominado de incompatibilidade vegetativa (ou também referida como incompatibilidade somática ou de heterocário). A incompatibilidade vegetativa reduz os riscos da transmissão de elementos citoplasmáticos infecciosos, como os vírus de RNA dupla fita (dsRNAs) e a exploração por genótipos agressivos, sendo portanto um mecanismo de auto - defesa dos fungos, uma vez que estes não possuem uma compartimentalização celular completa (Glass et al., 2000).

As características comuns das reações de incompatibilidade vegetativa incluem o tamponamento dos septos, presumivelmente para compartimentalizar os segmentos da hifa, a vacuolização do citoplasma, a degradação de organelas e o descolamento e encolhimento da membrana plasmática em relação à parede celular. Estas mudanças ultra - estruturais nas células em processo de morte, são consistentes com as características associadas ao programa de morte celular em eucariontes multicelulares (PCD ou apoptose) (Glass et al., 2000).

Jacobson et al. (1998) estudaram, por microscopia óptica e microscopia eletrônica de transmissão, as reações de incompatibilidade vegetativa em duas linhagens de $N$. crassa diplóides parciais para dois loci het respectivamente. Os autores verificaram que estas linhagens contendo um único loco het em heterozigose eram viáveis, mas possuíam uma baixa taxa de crescimento. Estas linhagens foram examinadas microscopicamente para se evidenciar o processo de morte celular. 
Observou-se que aproximadamente $15 \%$ das células distribuídas aleatoriamente nas colônias estavam mortas ou em processo de morte celular. A microscopia eletrônica revelou uma extensiva degradação das organelas e plasmólise. Por fim, o citoplasma era fragmentado em pequenas vesículas envolvidas por membrana plasmática. Observou-se também um re-crescimento da hifa, a partir de compartimentos vizinhos, para dentro das regiões mortas da hifa, com a observação de material elétron-denso em torno das regiões de re-crescimento. Devido o fato do re-crescimento acontecer logo após o início da degradação celular, os restos ou fragmentos das organelas eram visíveis na região elétron-densa em torno das novas células em crescimento dentro da hifa.

Aimi et al. (2002) observaram processos de morte celular em regiões de anastomose de hifas entre fungos pertencentes a diferentes grupos de compatibilidade vegetativa de Helicobasidium monpa. Verificou-se a presença de segmentos da hifa intensamente corados com o corante brometo de etídio, evidenciando a morte celular devido à reação de incompatibilidade vegetativa.

Portanto a observação em algumas regiões dos heterocários aqui estudados, da existência de segmentos da hifa contendo material granuloso, não sendo observado núcleos íntegros (Figura 17 b) e a existência de segmentos intensamente corados (Figura c e d) pode ser um indício de um processo de morte celular devido a algum nível de reação de incompatibilidade. Embora as colônias heterocarióticas aqui estudadas possuíssem um crescimento vigoroso, tais reações de incompatibilidade poderiam estar ocorrendo em algum nível, resultando no padrão de recombinantes aqui obtidos.

Stasz et al. (1989) ao estudarem as progênies obtidas a partir de cruzamentos intra e interespecíficos envolvendo algumas espécies de Trichoderma, via fusão de protoplastos, verificaram a obtenção de recombinantes instáveis os quais freqüentemente originavam setores de crescimento vigoroso. Além disso, todos os recombinantes analisados eram semelhantes, em relação aos marcadores de auxotrofia e aos marcadores isoenzimáticos utilizados, a somente um dos parentais utilizados nos cruzamentos. Os autores sugeriram a ocorrência de reações de incompatibilidade como eventos pós-fusão, as quais resultariam nos padrões de recombinantes obtidos. Os autores denominaram estes eventos como compatibilidade vegetativa limitada. 
Se estas reações de incompatibilidade realmente estiverem acontecendo, estas poderiam ser uma explicação para a ocorrência de supostos processos de transformação entre núcleos como sugerido anteriormente (item 4.3), onde os núcleos parentais provenientes do parental não prevalente seriam degradados e parte do material genético poderia ser incorporado em núcleos íntegros (oriundos do parental prevalente). No entanto estudos adicionais das hifas heterocarióticas devem ser realizados no sentido de se ter maiores evidências da possível ocorrência de reações de incompatibilidade nestes heterocários aqui estudados. Tais estudos incluiriam análises de microscopia óptica utilizando corantes específicos para células mortas, ou em processo de morte celular (como o brometo de etídio ou o evans blue) em contraste com corantes específicos para células vivas (como o acridina orange) (Aimi et al., 2002), além de estudos de ultraestrutura por microscopia eletrônica de transmissão, como o realizado para os diplóides parciais para o locus het de N. crassa descritos anteriormente (Jacobson et al., 1998). 


\section{CONCLUSÕES}

De acordo com os resultados apresentados, os quais mostram um padrão instável dos recombinantes obtidos e a semelhança destes com somente um dos parentais envolvidos nos cruzamentos, propõe-se a ocorrência de outros eventos de recombinação somática no heterocário diferente daqueles descritos para o ciclo parassexual, incluindo a parameiose. Tanto no ciclo parassexual como na parameiose, é necessário a ocorrência de fusões nucleares no heterocário, mesmo que transientes e instáveis, para gerar os recombinantes. $\mathrm{O}$ fato da maioria dos recombinantes obtidos possuirem o genótipo de somente um dos parentais, e a baixa freqüência na detecção de recombinantes via marcadores de auxotrofia e de RAPD, sugere que tais fusões nucleares não tenham ocorrido. Assim, propõe-se aqui a ocorrência de um novo mecanismo de recombinação somática onde no heterocário os núcleos de um dos parentais envolvidos nos cruzamentos seriam degradados (parental não prevalente) e parte do material genético destes núcleos seriam incorporados pelos núcleos íntegros provenientes do parental prevalente. Este mecanismo de recombinação somática tem sido proposto por alguns autores ao descreverem a obtenção de recombinantes, apresentando as mesmas características descritas aqui, em outras espécies de Trichoderma e mesmo em outras espécies de fungos filamentosos. Este é o primeiro trabalho que envolve a análise do perfil cromossomal dos recombinantes em relação aos parentais, além de uma extensiva análise com o uso de marcadores moleculares a nível de DNA em espécies do gênero Trichoderma (no caso o RAPD), diferindo dos anteriormente realizados onde poucos recombinantes foram estudados ou estes foram analisados via marcadores isoenzimáticos. Os resultados dos estudos citológicos mostraram que na formação dos conídios estes recebem somente um núcleo proveniente da fiálide e que a existência de 
conídios verdes bi até multinucleados é provavelmente devida a divisões mitóticas do núcleo original durante a maturação dos conídios. Os estudos citológicos do heterocário demostraram a presença de núcleos íntegros em diferentes conformações, nas diferentes regiões da hifa, sugerindo um processo ativo de movimento destes, o que ficou evidente em uma região de anastomose apresentando a passagem de um núcleo de formato bem alongado. Outro fato foi a ocorrência em certas regiões da hifa da presença de material granuloso no citoplasma, sem ser possível observar a presença de núcleos íntegros, além disso algumas hifas apresentaram-se intensamente coradas, sugerindo algum processo de morte celular. Estas observações sugerem a ocorrência de algum processo de incompatibilidade vegetativa no heterocário, podendo ser uma explicação à origem do mecanismo de recombinação proposto. No entanto novos estudos devem ser realizados com o uso de corantes específicos para compartimentos celulares mortos e para compartimentos vivos além de estudos de microscopia eletrônica de transmissão, com o objetivo de se ter melhores evidências da ocorrência de reações de incompatibilidade. 


\section{REFERÊNCIAS BIBLIOGRÁFICAS}

AIMI, T.; YOTSUTANI, Y.; MORINAGA, T. Cytological analysis of anastomoses and vegetative incompatibility reactions in Helicobasidium monpa. Current Microbiology, v.44, n.2, p.148-152, 2002.

ALEKSENKO, A.Y.; CLUTTERBUCK, A.J. Recombinational stability of replicating plasmids in Aspergillus nidulans during transformation, vegetative growth and sexual reproduction. Current Genetics, v.28, p.87-93, 1995.

ANAGNOSTAKIS, S.L. Conversion to curative morphology in Endothia parasitica and its restriction by vegetative incompatibility. Mycologia, v.75, p.777-780, 1983.

ARIAS, S.M.S.; MENDES-COSTA, M.C.; MACHADO, J.C. Aspecto citológico de Diaporthe phaseolum f. sp. meridionalis. Summa Phytopathologica, v.23, p.128131, 1997.

ARNAU, J.; HOUSEGO, A.P.; OLIVER, R.P. The Use of RAPD markers in the genetic analysis of the plant pathogenic fungus Cladosporium fulvum. Current Genetics, v.25, p.438-444, 1994.

ARNAU, J.; OLIVER, R. P. Inheritance and alteration of transforming DNA during an induced parasexual cycle in the imperfect fungus Cladosporium fulvum. Current Genetics, v.23, p.508-511, 1993. 
BAGAGLI, E.; FURLANETO, M.C.; PIZZIRANI-KLEINER, A.; AZEVEDO, J.L. Genetic recombinants in Trichoderma pseudokoningii (Rifai) without typical parasexuality. Canadian Journal of Microbiology, v.41, p.1132-1134, 1995.

BAGAGLI, E.; VALADARES, M.C.C.; AZEVEDO, J.L. Parameiosis in the enthomopathogenic fungus Metarhizium anisopliae (Metsch) Sorokin. Revista Brasileira de Genética, v.14, n.2, p.261-272, 1991.

BALL, C.; HAMLYN, P.F. The genetics of Acremonium chrysogenum. Revista Brasileira de Genética, v.1, p.83-96, 1978.

BALL, C.; HAMLYN, P.F. Genetic recombination studies with Cephalosporium acremonium related to the production of the industrially important antibiotic Cephalosporin. Revista Brasileira de Genética, v.5, p.1-13, 1982.

BELLO, V.A.; PACCOLA-MEIRELLES, L.D. Localization of auxotrophic and benomyl resistance markers through the parasexual cycle in the Beauveria bassiana (Bals.) vuill entomopathogen. Journal of Invertebrate Pathology, v.72, p.119$125,1998$.

BERTOLDI, M.; CATEN, C.E. Isolation and haploidization of heterozygous diploid strains in a species of Humicola. Journal of General Microbiology, v.91, p.63-73, 1975.

BISSET, J. A revision of the genus Trichoderma. I. Section Longibrachiatum sect. nov. Canadian Journal of Botany, v.62, p.924-931, 1984.

BISSET, J. A revision of the genus Trichoderma. II. Infrageneric classification. Canadian Journal of Botany, v.69, p.2357-2372, 1991a. 
BISSET, J. A revision of the genus Trichoderma. III. Section Pachybasium. Canadian Journal of Botany, v.69, p.2372-2417, 1991b.

BISSET, J. A revision of the genus Trichoderma. IV. Additional notes on section Longibrachiatum. Canadian Journal of Botany, v.69, p.2418-2420, 1991c.

BONATELLI JUNIOR., R.; AZEVEDO, J.L.; VALENT, G.V. Parassexuality in a citric acid producing strain of Aspergilus niger. Revista Brasileira de Genética, v.6, p.399-405, 1983.

BOUCHERIE, H.; BERNET, J. Protoplasmic incompatibility and self-lysis in Podospora anserina: enzyme activities associated with cell destruction. Canadian Journal of Botany, v.56, p.2171-2176, 1978.

BUENO-GOMES, R. Análise genética e molecular da parassexualidade em Penicillium chrysogenum. Rio Claro, 2000. 140p. Tese (Doutorado) - Instituto de Biociências, Universidade Estadual Paulista "Julio de Mesquita Filho".

CATEN, C.E. Vegetative incompatibility and cytoplasmic infection in fungi. Journal of General Microbiology, v.72, p.221-229, 1972.

CATEN, C.E. Parasexual processes in fungi. In: GULL, K.; OLIVER, S.G. The Fungal Nucleus. Cambridge: Cambridge University Press, 1981. p.191-214.

CLUTTERBUCK, A.J. Parasexual recombination in fungi. Journal of Genetics, v.75, n.3, p.281-286, 1996.

COLLINS, R.A.; SAVILLE, B.J. Independent transfer of mitochondrial chromosomes and plasmids during unstable vegetative fusion in Neurospora. Nature, v.345, p.177-179, 1990. 
DALZOTO, P.R. Investigação dos processos de recombinação no deuteromiceto Beauveria bassiana vuill por meio de RAPD. Curitiba, 1999. 99p. Dissertação (Mestrado) - Universidade Federal do Paraná.

DAY, A.W. Chromosome transfer in dikaryons of a smut fungus. Nature, v.273, p.753-755, 1978.

DAY, A.W. Nonmeiotic mechanisms of recombination in the anther smut microbotryum violaceum. International Journal of Plant Science, v.159, n.2, p.185-191, 1998.

DAY, A.W.; JONES, J.K. The production and characteristics of diploids in Ustilago violacea. Genetical Research, v.11, p.63-81, 1968.

DEBETS, A.J.M. Parasexuality in fungi: mechanisms and significance in wild populations. In: COUTEAUDIER, P.B.Y.; CLARKSON, J. Molecular variability of fungal pathogens. New York: CAB International, 1998. chap.3, p.41-53.

DEBETS, A.J.M.; SWART, K.; HOEKSTRA, R.F.; BOS, C.J. Genetic maps of eight linkage groups of Aspergillus niger based on mitotic mapping. Current Genetics, v.23, p.47-53, 1993.

DEBETS, F.; YANG, X.; GRIFFITHS, A.J.F. Vegetative incompatibility in Neurospora: its effect on horizontal transfer of mitochondrial plasmids and senescence in natural populations. Current Genetics, v.26, p.113-119, 1994.

DURAND, N.; REYMOND, P.; FÈVRE, M. Randomly amplified polymorphic DNAs assess recombination following an induced parasexual cycle in Penicillium roqueforti. Current Genetics, v.24, p.417-420, 1993. 
ELLINGBOE, A.H. Illegitimacy and specific factor transfer in Schizophyllum commune. Proceedings of the National Academy of Sciences of the United States of America, v.49, p.286-292, 1963.

ELLINGBOE, A.H. Somatic recombination in dikaryon K of Schizophyllum commune. Genetics, v.49, p.247-251, 1964.

ESPOSITO, E.; SILVA, M. Systematics and environmental application of the genus Trichoderma. Critical Reviews in Microbiology, v.24, n.2, p.89-98, 1998.

FRANKEL, C. Meiotic-like recombination in vegetative dikaryons of Schizophylum commune. Genetics, v.92, p.1121-1126, 1979.

FURLANETO, M. C. Recombinação genética e produção de celulase em Trichoderma pseudokoningii var. Rifai. Piracicaba, 1989. 152p. Dissertação (Mestrado) Escola Superior de Agricultura “Luiz de Queiroz", Universidade de São Paulo.

FURLANETO, M.C.; PIZZIRANI-KLEINER, A.A. Intraspecific hybridisation of Trichoderma pseudokoningii by anastomosis and protoplasts fusion. FEMS Microbiology Letters, v.90, p.191-196, 1992.

GARNJOBST, L.; WILSON, J.F. Heterokaryosis and protoplasmic incompatibility in Neurospora crassa. Proceedings of the National Academy of Science of the United State of America, v.42, p.613-618, 1956.

GLASS, N.L.; JACOBSON, D.J.; PATRICK, K.T.S. The genetics of hyphal fusion and vegetative incompatibility in filamentous ascomycete fungi. Annual Review of Genetics, v.34, p.165-186, 2000. 
GLASS, N.L.; KULDAU, G.A. Mating type and vegetative incompatibility in filamentous ascommycetes. Annual Review of Phytopathology, v.30, p.201-224, 1992.

GÓMEZ, I.; CHET, I.; HERRERA-ESTRELLA, A. Genetic diversity and vegetative compatibility among Trichoderma harzianum isolates. Molecular and General Genetics, v.256, p.127-135, 1997.

GRESSEL, J.B.; HARTMANN, K.M. Morphogenesis in Trichoderma. Action spectrum of photoinduced sporulation. Planta, v.79, p.271-274, 1968.

GRIFFITHS, A.J.F.; KRAUS, S.R.; BARTON, R.; COURT, D.A.; BERTRAND, H. Heterokaryotic transmission of senescence plasmid DNA in Neurospora. Current Genetics, v.17, p.139-145, 1990.

HALTRICH, D.; NIDETZKY, B.; KULBE, K.D.; STEINER, W.; ZUPANCIC, S. Production of fungal xylanases. Bioresearch Technology, v.58, p.137-142, 1996.

HAMMIL, T.M. Electron microscopy of phialides and conidiogenesis in Trichoderma saturnisporum. American Journal of Botany, v.61, n.1, p.15-24, 1974.

HARMAN, G.E. Development tactics for biocontrol fungi in plant pathology. In: BAKER, R.R.; DUNN, P.E. New directions in biological control. New York: Willey - Liss, 1990. p.779-792.

JACOBSON, D.J.; BEURKENS, K.; KLOMPARENS, K.L. Microscopic and ultrastructural examination of vegetative incompatibility in partial diploids heterozigous at het loci in Neurospora crassa. Fungal Genetics and Biology, v.23, p.45-46, 1998. 
KATAYAMA, A.; MATSUMURA, F. Degradation of organochlorine pesticides, particularly endosulfan, by Trychoderma harzianum. Environmental and Toxicological Chemistry, v.12, p.1059-1065, 1993.

KEMPKEM, F. Horizontal transfer of a mitochondrial plasmid. Molecular and General Genetics, v.248, p.89-94, 1995.

KINSEY, J.A. Tad, a LINE-like transposable element of Neurospora, can transpose between nuclei in heterokaryons. Genetics, v.126, p.317-323, 1990.

KINSEY, J.A. Transnuclear retrotransposition of the TAD element of Neurospora. Proceedings of the National Academy of Sciences of the United States of America, v.90, p.9384-9387, 1993.

KRONLAND, W.C.; STANGHELLINI, M.E. Clean slide technique for the observation of anastomosis and nuclear condition of Rhizoctonia solani. Phytopathology, v.78, p.820-822, 1988 .

KUBICEK, C.P. The cellulase proteins of Trichoderma reesei: structure, multiplicity, mode of action and regulation of formation. Advances in Biochemistry and Engineering Biotechnology, v.45, p.1-27, 1992.

LABARÈRE, J.; BÉGUERET, J.; BERNET, J. Incompatibility in Podospora anserina: comparative properties of the antagonistic cytoplasmic factors of a nonallelic system. Journal of Bacteriology, v.120, p.854-860, 1974.

LEONARD, T.J.; DICK, S.; GABER, R.F. Internuclear genetic transfer in vegetative dikaryons of Schizophyllum commune. I. Di-mon mating analysis. Genetics, v.88, p.13-26, 1978a. 
LEONARD, T.J.; GABER, R.F.; DICK, S. Internuclear genetic transfer in dikaryons of Schizophyllum commune. II. Direct recovery and analysis of recombinant nuclei. Genetics, v.89, p.685-693, 1978 b.

LESLIE, J.F. Fungal vegetative compatibility. Annual Review of Phytopathology, v.31, p.127-150, 1993.

LEUCHTMANN, A.; PETRINI, O.; SAMUELS, G. J. Isozyme subgroups in Trichoderma section Longibrachiatum. Mycologia, v.88, n.3, p.384-394, 1996.

LORITO, M.; HARMAN, G.E.; HAYES, C.K.; BRODWAY, R.M.; TRONSMO, A.; WOO, S.L.; PIETRO, A. Di. Chitinolytic enzymes produced by Trichoderma harzianum: antifungal activity of purified endochitinase and chitobiosidase. Phytopathology, v.83, p.302-307, 1993.

LUMSDEN, R.D.; LOCKE, J.C. Biological control of damping-off caused by Pythium ultimum and Rhizoctonia solani in soiless mix. Phytopathology, v.79, p.361-366, 1989.

MAREK, S.; WU, J.; GLASS, N.L.; GILCHRIST, D.G.; BOSTOCK, R. Programmed cell death in fungi: heterokaryon incompatibility involves nuclear DNA degradation. Phytopathology, v.88, p.58-63, 1998.

MARGOLLES-CLARCK, E.; ILMEN, M.; PENTTILA, M. Expression patterns of ten hemicellulase genes of the filamentous fungus Trichoderma reesei on various carbon sources. Journal of Biotechnology, v.57, p.167-172, 1997.

MCCABE, P.M.; GALLAGHER, M.P.; DEACON, J.W. Microscopic observation of perfect hyphal fusion in Rhizoctonia solani. Mycological Research, v.103, p.487490, 1999. 
MYLYK, O.M. Heteromorphism for heterokaryon incompatibility genes in natural populations of Neurospora crassa. Genetics, v.83, p.275-284, 1976.

NADALINI, M.F.C. Caracterização genética e produção de celulases em Trichoderma pseudokoningii. Rio Claro, 1997. 142p. Tese (Doutorado) - Instituto de Biociências, Universidade Estadual Paulista "Julio de Mesquita Filho".

NADALINI, M.F.C.; PIZZIRANI-KLEINER, A.A.; CARMONA, E.C. Cellulolytic activity of wild and mutant Trichoderma pseudokoningii. Journal of Basic Microbiology, v.39, n.5-6, p.351-356, 1999.

NEWHOUSE, J.R.; MACDONALD, W.L. The ultrastructure of hyphal anastomoses between vegetatively compatible and incompatible virulent and hypovirulent strains of Cryphonectria parasitica. Canadian Journal of Botany, v.69, p.602-614, 1991.

NEWTON, A.C.; OSBOURN, A.E.; CATEN, C.E. Heterokaryosis and vegetative incompatibility in Stagonospora nodorum. Mycologia, v.90, n.2, p.215-225, 1998.

PACCOLA-MEIRELLES, L.D.; AZEVEDO, J.L. Parasexuality in Beauveria bassiana. Journal of Invertebrate Pathology, v.57, p.172-176, 1991.

PARAG, Y. Studies in somatic recombination in dikaryons of Schizophyllum commune. Heredity, v.17, p.305-318, 1962.

PE'ER, S.; CHET, I. Trichoderma protoplast fusion: a tool for improving biocontrol agents. Canadian Journal of Microbiology, v.36, p.6-9, 1990.

PECCHIA, S.; ANNÉ, J. Fusion of protoplast from antagonistic Trichoderma harzianum strains. Acta Horticultural, v.255, p.303-311, 1989. 
PERKINS, D.D. Main features of vegetative incompatibility in Neurospora. Fungal Genetics Newsletter, v.35, p.44-46, 1988.

PONTECORVO, G. The parassexual cycle in fungi. Annual Review of Microbiology, v.10, p.393-400, 1956.

PONTECORVO, G.; ROPER, J.A.; FORBES, E. Genetic recombination without sexual reproduction in Aspergillus niger. Journal of General Microbiology, v.8, p.198$210,1953$.

PRIMO, P.D.; CARTIA, G.; KATAN, T. Vegetative compatibility and heterokaryon stability in Fusarium oxysporum f. sp. radicis-lycopersici from Italy. Plant Pathology, v.50, p.371-382, 2001.

PROSSER, J.I. Kinetics of filamentous growth and branching. In: GOW, N.A.R.; GADD, G. M. The growing fungus. London: Chapman \& Hall, 1994. p.301-318.

PUHALLA, J.E.; MAYFIELD, J.E. The mechanism of heterokaryotic growth in Verticillium dahliae. Genetics, v.76, p.411-422, 1974.

PUHALLA, J.E.; SPEITH, P.T. A comparison of heterokaryosis and vegetative incompatibility among varieties of Gibberella fujikuroi (Fusarium moniliforme). Experimental Mycology, v.9, p.39-47, 1985.

RAEDER, U.; BRODA, P. Rapid preparation of DNA from filamentous fungi. Letters of Applied Microbiology, v.1, p.17-20, 1985.

RAYNER, A.D.M. The challenge of the individualistic mycelium. Mycologia, v.83, n.1, p.48-71, 1991. 
RICARD, J.L. Commercialization of a Trichoderma-based mycofungicide: some problems and solutions. Biocontrol News and Information, v.2, p.95-98, 1981.

RIFAI, M.A. A revision of the genus Trichoderma. Mycological Papers, v.116, p.1$56,1969$.

ROBINOW, C.F.; CATEN, C.E. Mitosis in Aspergillus nidulans. Journal of Cell Science, v.5, p.403-431, 1969.

SAMBROOK, J.; FRITSCH, E.F.; MANIATIS, T. Molecular cloning: a laboratory manual. Cold Spring Harbor: Cold Spring Harbor Laboratory Press, 1989. 3v.

SAMUELS, G. J. Trichoderma: a review of biology and systematics of the genus. Mycological Research, v.100, n.8, p.923-935, 1996.

SILVA, I.F.; PIZZIRANI-KLEINER, A.A. Caracterização genética por RAPD de recombinantes em Trichoderma pseudokoningii. Summa Phytopathologica, v.25, p.233-239, 1999.

SIVAN, A.; HARMAN, G.E.; STASZ, T.E. Transfer of isolated nuclei into protoplasts of Trichoderma harzianum. Applied and Environmental Microbiology, v.56, n.8, p.2404-2409, 1990.

SMITH, W.H. Forest occurrence of Trichoderma species: emphasis on potential organochloride (Xenobiotic) degradation. Ecotoxicology and Environmental Safety: Environmental Research, v.32, p.179-183, 1995.

STASZ, T.E.; HARMAN, G.E. Nonparental progeny resulting from protoplast fusion in Trichoderma in the absence of parassexuality. Experimental Mycology, v.14, p.145-159, 1990. 
STASZ, T.E.; HARMAN, G.E.; GULLINO, M.L. Limited vegetative compatibility following intra and interspecific protoplast fusion in Trichoderma. Experimental Mycology, v.13, p.364-371, 1989.

STASZ, T.E.; HARMAN, G.E.; WEEDEN, N.F. Protoplast preparation and fusion in two biocontrol strains of Trichoderma harzianum. Mycologia, v.80, n.2, p.141-150, 1988.

TABET, J.C.; LICHTENSTEIN, E.P. Degradation of [14C] photodieldrin by Trichoderma viride as affected by other insecticides. Canadian Journal of Microbiology, v.22, p.1345-1350, 1976.

TANAKA, Y.; MURATA, N.; KATO, H. Behavior of nuclei and chromosomes during ascus development in the matting between either rice - strain or weeping lovegrass - strain and ragi - strain of Pyricularia. Annals of Phytopathology Society of Japan, v.45, p.182-191, 1979.

VERDOES, J.C.; PUNT, P.J.; VAN DER BERG, P.; DEBETS, F.; STOUTHAMER, A.H.; VAN DEN HONDEL, C.A.M.J.J. Characterization of an efficient gene cloning strategy for Aspergillus niger based on an autonomously replicating plasmid: cloning of the nicB gene of A. niger. Gene, v.46, p.159-165, 1994.

ZEIGLER, R.S.; SCOTT, R.P.; LEUNG, A.A.B.H.; KUMAR, J.; NELSON, R.J. Evidence of parasexual exchange of DNA in the rice blast fungus challenges its exclusive clonality. Genetics, v.87, n.3, p.284-294, 1997. 